ESTIMATED WATER-QUALITY CONDITIONS AND POTENTIAL

DOWNSTREAM CHANNEL EFFECTS OF THE PROPOSED ROCK

CREEK AND WOLFORD MOUNTAIN RESERVOIRS,

NORTH-CENTRAL COLORADO

By David L. Butler

U.S. GEOLOGICAL SURVEY

Water-Resources Investigations Report 89-4177

Prepared in cooperation with the

COLORADO RIVER WATER CONSERVATION DISTRICT

Denver, Colorado 
DEPARTMENT OF THE INTERIOR

MANUEL LUJAN, JR., Secretary

U.S. GEOLOGICAL SURVEY

Dallas L. Peck, Director

For additional information write to:

District Chief

U.S. Geological Survey

Box 25046, Mail Stop 415

Federal Center

Denver, C0 80225-0046
Copies of this report can be purchased from:

U.S. Geological Survey Books and Open-File Reports Section Box 25425

Federal Center

Denver, CO 80225-0425 
Abstract----

Introduction---

Purpose and scope----_-n 3

Description of study area and stream discharge---- 5

Rock Creek basin---- 5

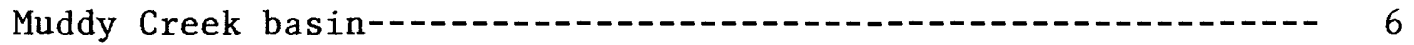

Acknowledgments-- 6

Water temperature-1- 7

Description of temperature model- 7

Calibration--- 9

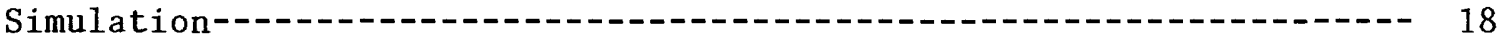

Rock Creek Reservoir---

Wolford Mountain Reservoir-- 29

Water quality-- 38

Specific conductance and dissolved solids-_... 38

Major inorganic constituents--

Phosphorus and nitrogen---_- 55

Dissolved oxygen--- 61

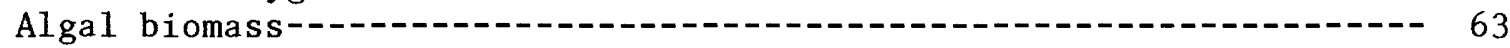

Sediment discharge and reservoir sedimentation-_- 72

Rock Creek Reservoir---1- 72

Wolford Mountain Reservoir--1-0 75

Downstream channel degradation---- 84

Rock Creek damsite--_e 86

Wolford Mountain damsite-_- 90

Summary--0-1-0 95

Selected references---1-- 98

FIGURES

Figure 1. Map showing location of the proposed Rock Creek and Wolford Mountain Reservoirs and data-collection sites----- 4

2. Schematic three-dimensional view of an idealized reservoir and horizontal volume element used in the temperature model----

Page

3-38. Graphs showing:

3. Measured and simulated temperature profiles for Williams Fork Reservoir, 1979--...

4. Measured and simulated temperature profiles for Williams Fork Reservoir, 1980-- 14

5. Measured and simulated temperature profiles for Williams Fork Reservoir, 1986-87---15

6. Measured and simulated temperatures of outflow from Williams Fork Reservoir, 1979-80-_- 16

7. Measured and simulated temperatures of outflow from Williams Fork Reservoir, 1986-87-_- 17

8. Measured and simulated temperature profiles for Green Mountain Reservoir, 1986-87--0 
Figures 3-38. Graphs showing--Continued:

Page

9. Measured and simulated temperatures of outflow from

Green Mountain Reservoir, 1986-87---_-

10. Simulated temperature profiles for Rock Creek

Reservoir, 1957 and 1962-10

11. Simulated temperature profiles for Rock Creek Reservoir., 1972 and 1977-10 26

12. Simulated inflow and outflow temperatures for Rock Creek Reservioir, 1957 and 1962---_--

13. Simulated inflow and outflow temperatures for Rock Creek Reservoir, 1972 and 1977-_-n

14. Simulated temperature profiles for Wolford Mountain Reservoir, 1976-_.-.

15. Simulated temperature profiles for Wolford Mountain Reservoir, 1977--_- 32

16. Simulated temperature profiles for Wolford Mountain Reservoir, 1984- 33

17. Simulated temperature profiles for Wolford Mountain Reservoir, 1987- 34

18. Simulated inflow and outflow temperatures for Wolford Mountain Reservoir, 1976 and 1977-_.- 36

19. Simulated inflow and outflow temperatures for 1984 and measured inflow and simulated outflow temperatures for 1987 for Wolford Mountain Reservoir-_-

20. Measured and simulated specific-conductance profiles for Williams Fork and Green Mountain Reservoirs, 1987

21. Measured and simulated specific conductance of outflow from Williams Fork Reservoir, 1986-87-_-_--

22. Measured and simulated specific conductance of outflow from Green Mountain Reservoir, 1986-87-_.-- 42

23. Simulated specific-conductance profiles for Rock Creek Reservoir, 1957, 1972, and 1977-_ 44

24. Simulated inflow and outflow specific conductance for Rock Creek Reservoir, 1957 and 1962-_- 45

25. Simulated inflow and outflow specific conductance for Rock Creek Reservoir, 1972 and 1977-_. 46

26. Simulated specific-conductance profiles for Wolford Mountain Reservoir, 1976-.

27. Simulated specific-conductance profiles for Wolford Mountain Reservoir, 1984-

28. Simulated specific-conductance profiles for Wolford Mountain Reservoir, 1987-_.

29. Simulated inflow and outflow specific conductance for Wolford Mountain Reservoir, 1976 and 1977-_-_ 50

30. Simulated inflow and outflow specific conductance for 1984 and measured inflow and simulated outflow specific conductance for 1987 for Wolford Mountain

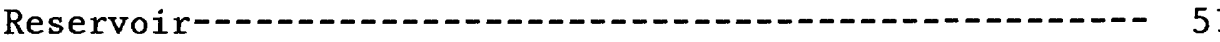

31. Results of algal-growth-potential analyses for Rock Creek near Toponas, 1987-- 
Figures 3-38. Graphs showing--Continued:

32. Results of algal-growth-potential analyses for Muddy Creek at Kremmling, 1987-n

33. Relation of suspended-sediment discharge to stream discharge at gaging station 09060500 , Rock Creek near Toponas-- 74

34. Relation of bedload discharge to stream discharge at gaging station 09060500, Rock Creek near Toponas------- 76

35. Relation of suspended-sediment discharge to stream discharge, March through August, rising stage, at gaging station 09041500, Muddy Creek at Kremmling------

36. Relation of suspended-sediment discharge to stream discharge, March through August, falling stage, at gaging station 09041500, Muddy Creek at Kremmling-----

37. Relation of suspended-sediment discharge to stream discharge, September through February, at gaging station 09041500, Muddy Creek at Kremmling-......-

38. Relation of bedload discharge to stream discharge at gaging station 09041500, Muddy Creek at Kremmling------

39. Schematic of the armoring method for estimating channel degradation--.-.

40. Map showing approximate location of surveyed section and channel cross sections downstream from the Rock Creek damsite--

41. Graph showing particle-size distribution of bed material from pebble-count data collected downstream from the

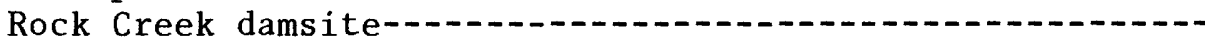

42. Map showing approximate location of surveyed section and channel cross sections downstream from the Wolford Mountain damsite-1..-

43. Graph showing particle-size distribution of bed material from pebble-count data collected downstream from the Wolford Mountain damsite-..

44. Graph showing particle-size distribution of bed material from sieve-analysis data collected downstream from the Wolford Mountain damsite-1.

\section{TABLES}

Table 1. Selected descriptive data for Williams Fork and Green Mountain Reservoirs ending dates and flushing rates for the 2. Beginning and ending dates and flushing rates for the
calibration periods used in the temperature model for Williams Fork and Green Mountain Reservoirs--..-

3. Selected descriptive data for the proposed Rock Creek and
Wolford Mountain Reservoirs

3. Selected descriptive data for the proposed Rock Creek and
Wolford Mountain Reservoirs outflow discharges and reservoir storage for Rock Creek Reservoir, April through October, for 1957, 1962, 1972, and 1977-....

5. Flushing rate of simulation periods for Rock Creek and Wolford Mountain Reservoirs- 
Table 6. Simulated monthly inflow and outflow discharges and reservoir storage for Wolford Mountain Reservoir, April through October, for 1976, 1977, 1984, and 1987--.-. 30

7. Summary of major inorganic-constituent and dissolvedsolids concentrations for samples collected from Rock and Muddy Creeks-_.-. 54

8. Measured and predicted total-phosphorus concentrations for Williams Fork and Green Mountain Reservoirs, 1986 and 1987-- 56

9. Summary of nutrient concentrations in samples collected from Rock and Muddy Creeks-_. 58

10. Simulated total-phosphorus concentrations in Rock Creek and Wolford Mountain Reservoirs-1 59

11. Nitrogen-loading data for Williams Fork and Green Mountain Reservoirs, 1986 and 1987-10 60

12. Measured and predicted total-nitrogen concentrations in Williams Fork and Green Mountain Reservoirs, 1986 and 1987-..- 61

13. Simulated total-nitrogen concentrations in Rock Creek and Wolford Mountain Reservoirs, 1985-87-_. 62

14. Biochemical-oxygen-demand data collected in 1986 and 1987 at gaging stations 09060500 , Rock Creek near Toponas and 09041500, Muddy Creek at Kremmling--

15. Measured and predicted chlorophyl1-a concentrations using chlorophyll model 1 for Williams Fork and Green Mountain Reservoirs, 1987-1

16. Measured and predicted chlorophyll-a concentrations using chlorophyll models 2, 3, and 4 for Williams Fork and Green Mountain Reservoirs, 1987-

17. Simulated chlorophyl1-a concentrations using chlorophyll models 1, 2, and 4 for Rock Creek and Wolford Mountain Reservoirs, 1985-87-_-

18. Simulated chlorophyll-a concentrations using chlorophyll model 3 for Rock Creek and Wolford Mountain Reservoirs, 1985-87--

19. Stream-discharge and sediment data collected during 1986 at gaging station 09060500, Rock Creek near Toponas-------

20. Regression relations of sediment discharge to stream discharge for gaging station 09060500, Rock Creek near Toponas--.-

21. Stream-discharge and sediment data collected during 1986 and 1987 water years at gaging station 09041500, Muddy Creek at Kremmling--.-

22. Regression relations of suspended-sediment discharge to stream discharge for gaging station 09041500, Muddy Creek at Kremmling-

23. Regression relation of bedload discharge to stream discharge for gaging station 09041500, Muddy Creek at Kremmling--

24. Estimated bankfull discharge and related hydraulic properties and bed-material size for a reach downstream from the damsites of the proposed Rock Creek and Wolford Mountain Reservoirs-- 


\section{CONVERSION FACTORS}

Inch-pound units used in this report may be converted to SI units (International System of Units) by using the following conversion factors:

\section{Multiply}

acre

acre-foot (acre-ft)

acre-foot per year (acre-ft/yr)

cubic foot per second $\left(\mathrm{ft}^{3} / \mathrm{s}\right)$

foot ( $\mathrm{ft}$ )

foot per second $(\mathrm{ft} / \mathrm{s})$

mile (mi)

pound per cubic foot $\left(1 \mathrm{~b} / \mathrm{ft}^{3}\right)$

square mile $\left(\mathrm{mi}^{2}\right)$

square feet $\left(\mathrm{ft}^{2}\right)$

ton

ton per day

ton per year (ton/yr)
$B y$

$$
4,047
$$$$
1,233
$$$$
1,233
$$

0.028317 .3048

.3048

1.609

16.02

2.590

.0929

.9072

.9072

.9072
To obtain

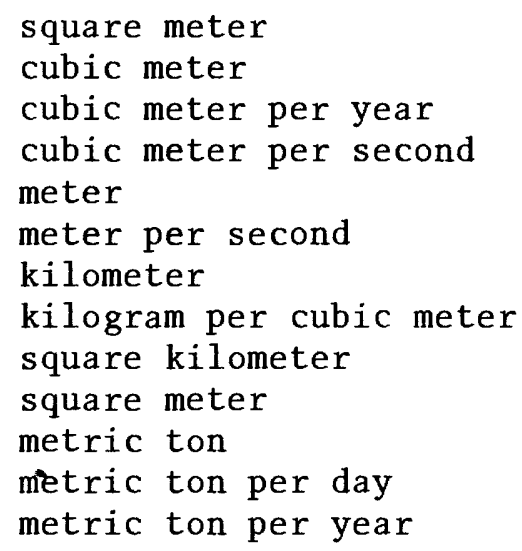

SI units used in this report may be converted to inch-pound units by using the following conversion factors:

\section{Multiply}

cubic meter

meter

millimeter $(\mathrm{mm})$

square meter
By

$$
\begin{gathered}
35.31 \\
3.281 \\
.03937 \\
10.76
\end{gathered}
$$

To obtain

cubic foot

foot

inch

square foot

Temperature in degree Celsius $\left({ }^{\circ} \mathrm{C}\right)$ may be converted to degree Fahrenheit $\left.{ }^{\circ} \mathrm{F}\right)$ by use of the following formula:

$$
\mathrm{F}=5 / 9\left({ }^{\circ} \mathrm{C}\right)+32
$$

The following terms and abbreviations also are used in this report:

$$
\begin{aligned}
& \text { microgram per liter }(\mu \mathrm{g} / \mathrm{L}) \\
& \text { microsiemens per centimeter }(\mu \mathrm{S} / \mathrm{cm}) \\
& \text { milligram per liter }(\mathrm{mg} / \mathrm{L}) \text {. }
\end{aligned}
$$

Sea leve1: In this report "sea level" refers to the National Geodetic Vertical Datum of 1929 (NGVD of 1929)--a geodetic datum derived from a general adjustment of the first-order level nets of both the United States and Canada, formerly called Sea Level Datum of 1929. 


\title{
ESTIMATED WATER-QUALITY CONDITIONS AND POTENTIAL DOWNSTREAM CHANNEL EFFECTS OF THE PROPOSED ROCK CREEK AND WOLFORD MOUNTAIN RESERVOIRS, NORTH-CENTRAL COLORADO
}

By David L. Butler

\begin{abstract}
Temperature distribution and water-quality conditions are described for the proposed Rock Creek and Wolford Mountain Reservoirs, located in northcentral Colorado. A one-dimensional temperature model was used to simulate water-temperature profiles and outflow temperature for the proposed reservoirs. Model-calibration results indicate the model may underestimate the temperature of water layers near the reservoir bottom by as much as 3 degrees Celsius. Simulated maximum surface temperatures in summer were 17 degrees Celsius for Rock Creek Reservoir and 19 degrees Celsius for Wolford Mountain Reservoir. Thermal stratification could develop in both reservoirs during most years. Simulated outflow temperatures for Rock Creek Reservoir were 5 to 8 degrees Celsius for years of normal and greater than normal runoff but were as warm as 15 to 16 degrees Celsius during late summer in 1977, a year of extreme drought that caused a large decrease in reservoir storage. Elevation of the outlet would affect the thermal structure and outflow temperature of Wolford Mountain Reservoir. Simulated outflow temperatures for Wolford Mountain Reservoir in late summer of a normal runoff year were about 9 to 10 degrees Celsius with the outlet at 7,410 or 7,420 feet and about 12 degrees Celsius with the outlet at 7,440 feet. Simulated outflow temperatures for Wolford Mountain Reservoir were as much as 5 degrees Celsius warmer for years that had less than normal runoff (1977) or greater than normal runoff (1984).
\end{abstract}

Specific conductance was simulated by modeling it as a conservative constituent using a water-quality routine in the temperature model. Specific conductance in the proposed reservoirs would be decreased due to dilution by high runoff. The reservoirs would have a dampening effect on specific conductance and on dissolved-solids concentrations in Rock and Muddy Creeks. Predominant ions in water stored in Rock Creek Reservoir primarily would be calcium and bicarbonate; predominant ions in water stored in Wolford Mountain Reservoir primarily would be calcium, sulfate, and bicarbonate.

Total-phosphorus, total-nitrogen, and chlorophyll-a concentrations were estimated using empirical models and water-quality data collected from 1985 to 1987. Models that predict dissolved-oxygen concentrations or dissolved-oxygen depletion rates in reservoirs were not considered suitable for simulation purposes for the proposed reservoirs. Simulated total-phosphorus concentrations ranged from 0.007 to 0.019 milligram per liter for Rock Creek Reservoir and from 0.049 to 0.11 milligram per liter for Wolford Mountain Reservoir. Simulated total-nitrogen concentrations were about 0.3 to 0.4 milligram per liter for Rock Creek Reservoir and about 0.7 to 0.8 milligram per liter for Wolford Mountain Reservoir. Simulated chlorophyll-a concentrations ranged from 0.02 to 4.9 micrograms per liter in Rock Creek Reservoir and 9.4 to 51 micrograms per liter in Wolford Mountain Reservoir. Simulated chlorophyll-a 
concentrations for Rock Creek Reservoir were similar to measured chlorophyll-a concentrations at nearby reservoirs. The models may overestimate chlorophyll-a concentrations in Wolford Mountain Reservoir.

Three sets of samples for analyses of algal-growth-potential were collected from each reservoir site in 1987. Water in Rock and Muddy Creeks may be nitrogen limiting for growth of algae. Addition of phosphorus to the samples from Rock Creek did not increase growth of the test alga.

Estimates of sediment discharge and sedimentation rates for the proposed reservoir sites were not substantially different than previously published results. The loss of storage capacity after 100 years was less than 1 percent for Rock Creek Reservoir and about 11 percent for Wolford Mountain Reservoir. Brief evaluations were made of potential channel degradation downstream from each proposed damsite. The method used to estimate channel degradation assumes an armoring layer would form in the stream channels after reservoir construction. Estimated depth of channel degradation in a 500-foot-long reach downstream from the Rock Creek damsite was 0.19 foot and in a 700-foot-long reach downstream from the Wolford Mountain damsite was 0.38 foot.

\section{INTRODUCTION}

Impoundment of water in reservoirs can affect the quality of the stored water. Potential effects include: (1) Thermal and chemical stratification, (2) changes in nutrient concentrations, (3) depletion of dissolved oxygen in the hypolimnion, (4) algal growth, and (5) sedimentation. In addition, reservoirs can affect downstream water quality. Possible downstream effects

include: (1) Changes in stream-temperature regime and chemical-constituent concentrations, (2) decreased sediment discharge, and (3) degradation of the channel downstream from the dam. For planning and environmental assessments of proposed reservoir sites, the water quality of the impounded water and instream water-quality effects need to be evaluated.

Two proposed reservoir sites near Kremmling in north-central Colorado (fig. 1) were studied by the U.S. Geological Survey in cooperation with the Colorado River Water Conservation District. The information gathered for the study, and described in this report, will be used by the Colorado River Water Conservation District to evaluate the sites for their suitability as waterstorage reservoirs. One site is on Rock Creek about $15 \mathrm{mi}$ west of Kremmling in southern Routt County and western Grand County. That reservoir would have a storage capacity of about 50,700 acre-ft. The other site is on Muddy Creek near Wolford Mountain, located about $3 \mathrm{mi}$ north of Kremmling. That reservoir would have a storage capacity of about 60,000 acre-ft. At present (1989), the Colorado River Water Conservation District plans to evaluate both sites but initially construct only one of the reservoirs. The reservoir would be part of joint use and water exchanges between the Colorado River Water Conservation District and other water users in Colorado. The reservoir could be used for water storage for domestic and irrigation supply, recreation, flow regulation, and possibly power generation. 


\section{Purpose and Scope}

The overall purpose of this report is to present an assessment of temperature distribution, selected water-quality conditions, sediment discharge, and to evaluate the potential for channel degradation at proposed reservoir sites on Rock and Muddy Creeks.

More specifically, this report:

1. Describes temperature distribution in the reservoirs and temperature of the outflow for greater than normal, less than normal, and normal runoff years.

2. Describes specific conductance in the reservoirs and the effect of reservoirs on specific conductance in the streams for greater than normal, less than normal, and normal runoff years; describes dissolved solids and major inorganic water quality of the reservoirs.

3. Presents determinations of phosphorus and nitrogen loading to the proposed reservoirs and estimates of in-reservoir concentrations.

4. Discusses dissolved-oxygen depletion in the reservoirs.

5. Presents estimations of potential algal growth in the reservoirs.

6. Presents estimates of total-sediment discharge in Rock and Muddy Creeks and the sedimentation rates in the reservoirs.

7. Describes potential for channel degradation downstream from the proposed damsites.

A mathematical model was used to determine the water-temperature distribution in the proposed reservoirs. The model was tested and calibrated using data collected at Williams Fork Reservoir (fig. 1) in 1979, 1980, 1986, and 1987 and data collected at Green Mountain Reservoir (fig. 1) in 1986 and 1987. Specific conductance was modeled as a conservative constituent using a waterquality routine in the temperature model. Water-quality data for gaging stations located on Rock and Muddy Creeks (fig. 1) were used to evaluate inorganic water quality of the proposed reservoirs. Total-phosphorus, totalnitrogen, and chlorophyll-a concentrations were estimated for the proposed reservoirs using empirical models and water-quality data collected during 1985-87 from Rock and Muddy Creeks. The empirical models were tested for use in the study area by using data collected from Williams Fork and Green Mountain Reservoirs during 1986 and 1987. Models that estimate dissolvedoxygen depletion or concentrations could not be used for simulation purposes. Dissolved-oxygen data for Williams Fork and Green Mountain Reservoirs were used as representative examples of dissolved-oxygen concentrations in reservoirs in the study area. Sediment data collected from Rock Creek during 1986 and from Muddy Creek during 1986 and 1987 were used to revise total-sediment discharge and sedimentation rates reported for the Rock Creek (Butler, 1987) and Wolford Mountain (Ruddy, 1987) sites. Potential channel degradation was estimated in a selected reach downstream from the proposed damsites on Rock and Muddy Creeks by using a method based on streambed armoring. Stream profiles and cross sections were surveyed, and particle size of the bed material was measured in the selected reaches in 1987 for determination of channel degradation. 


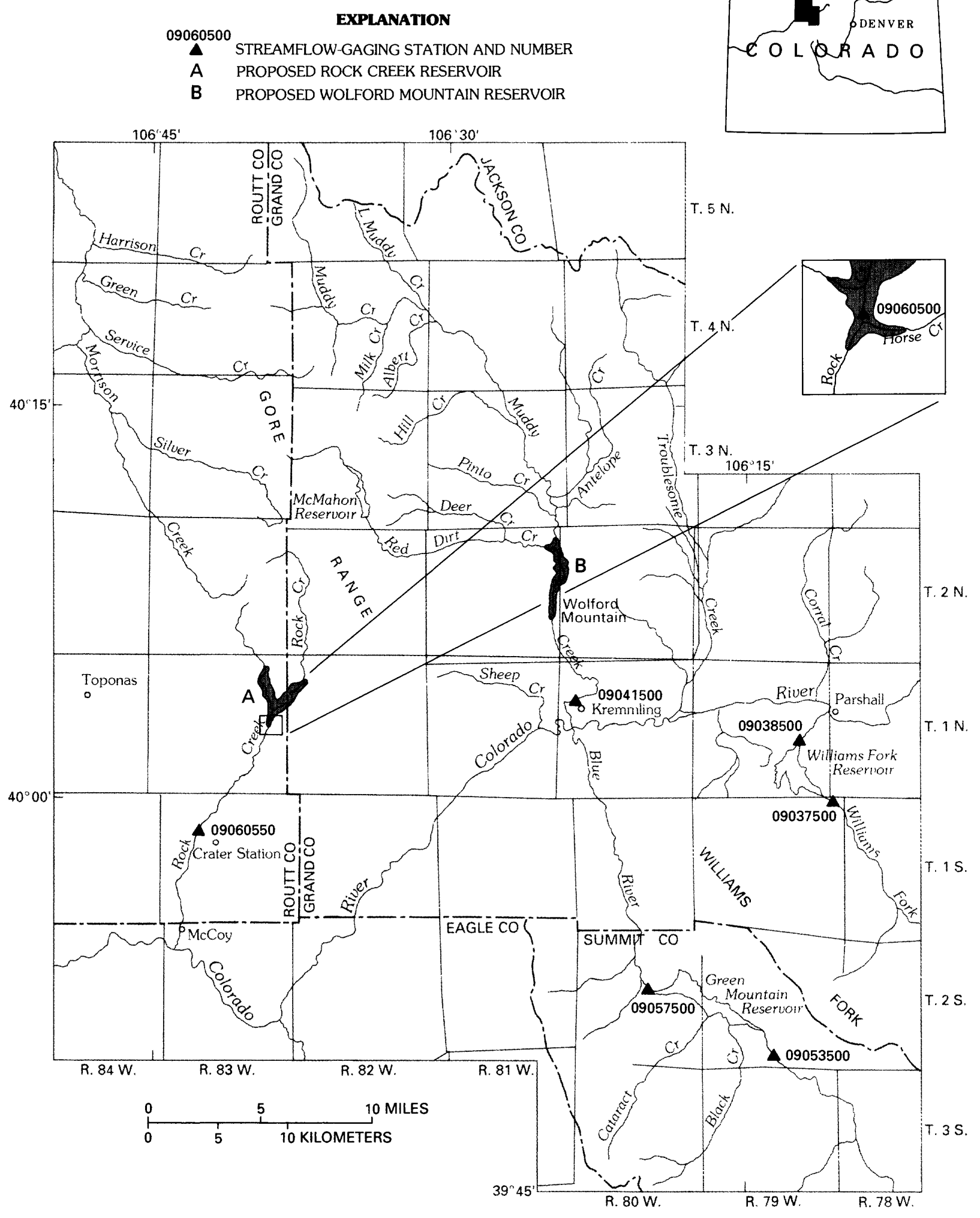

Figure 1.--Location of the proposed Rock Creek and Wolford Mountain Reservoirs and data-collection sites. 
Description of Study Area and Stream Discharge

\author{
Rock Creek Basin
}

From its headwaters at an elevation near 11,000 ft, Rock Creek flows generally south to its confluence with the Colorado River at McCoy (fig. 1). Rock Creek drains $192 \mathrm{mi}^{2}$; upstream from the proposed damsite, Rock Creek drains about $53 \mathrm{mi}^{2}$. The elevation of Rock Creek at the proposed damsite is about $8,520 \mathrm{ft}$. The basin upstream from the proposed damsite is characterized by foothills and upland meadows on the western slope of the Gore Range. Fir, pine, and aspen forest are interspersed with open areas of grassland and brush. Downstream from the damsite, the forests grade into scrub oak, mountain mahogany, pinyon pine, and juniper.

Outcrops in the Rock Creek basin upstream from the proposed damsite predominantly are Precambrian granitic rocks (Tweto, 1981). Small areas of sedimentary rocks of the Jurassic Morrison Formation occur in the Horse Creek basin, and sedimentary rocks of the Pennsylvanian Minturn Formation occur in the Long Park area. Outcrops in the Rock Creek basin downstream from Crater predominantly are sedimentary deposits.

The only inhabited towns in the Rock Creek basin are Toponas and McCoy. The drainage basin upstream from the reservoir site does not have a permanent population and is used for recreational purposes, livestock grazing, and logging.

Daily stream discharge was recorded for 28 years from October 1952 through September 1980 at gaging station 09060500, Rock Creek near Toponas, hereinafter referred to as the Toponas gage (fig. 1). The drainage basin area upstream from the Toponas gage is $47.6 \mathrm{mi}^{2}$. Average stream discharge for the period of record (water years 1953-80) was $32.9 \mathrm{ft}^{3} / \mathrm{s}(23,840 \mathrm{acre}-\mathrm{ft} / \mathrm{yr})$. The maximum recorded daily stream discharge was $494 \mathrm{ft}^{3} / \mathrm{s}$ in May 1976.

Seventy-eight percent of the annual stream discharge at the Toponas gage occurred during April through June, the snowmelt period in the Rock Creek basin. Stream discharge into the proposed reservoir would approximately equal the stream discharge at the Toponas gage plus stream discharge of Horse Creek, which flows into Rock Creek between the Toponas gage and the damsite. If stream discharge per unit drainage-basin area for Horse Creek basin and Rock Creek basin upstream from the Toponas gage are equivalent, then the average stream discharge for Horse Creek was $3.1 \mathrm{ft}^{3} / \mathrm{s}(2,267 \mathrm{acre}-\mathrm{ft} / \mathrm{yr})$. The estimated average stream discharge into the proposed reservoir was 26,107 acre-ft/yr for the period of record of the Toponas gage.

Daily stream discharge has been recorded since October 1984 at gaging station 09060550, Rock Creek at Crater (fig. 1), hereinafter referred to as the Crater gage. The drainage basin area upstream from the Crater gage is $72.6 \mathrm{mi}^{2}$. The average stream discharge from October 1984 through September 1987 (1985-87 water years) at the Crater gage was $40.8 \mathrm{ft}^{3} / \mathrm{s} \quad(29,560$ acre$\mathrm{ft} / \mathrm{yr})$. The maximum recorded daily stream discharge was $422 \mathrm{ft}^{3} / \mathrm{s}$ in May 1985 . 


\section{Muddy Creek Basin}

Muddy Creek generally flows south from its headwaters at an elevation of 10,600 ft, near Rabbit Ears Peak, to its confluence with the Colorado River near Kremmling (fig. 1). Muddy Creek drains about $290 \mathrm{mi}^{2}$ and occupies a broad basin on the east slope of the Gore Range. The elevation of Muddy Creek at the proposed damsite is 7,360 ft. Much of the vegetation in the basin consists of sagebrush and grassland and some irrigated hay meadows. At higher elevations, scrub oak, pine, and aspen forests predominate.

Much of Muddy Creek basin, including the Wolford Mountain Reservoir site, is located on Upper Cretaceous shales and sandstones of the Pierre Shale. A striking feature in the lower basin is Wolford Mountain, a fault block of Precambrian igneous rocks thrust over Cretaceous shales and sandstones. The east abutment of the proposed dam would be at the base of Wolford Mountain.

The only inhabited town in the Muddy Creek basin is Kremmling. Ranching is the primary land-use activity in the valley, with associated livestock grazing and hay meadows. Higher elevation areas of the basin along the northern and western boundary are used for recreation and logging.

Daily stream discharge has been recorded since April 1982 at gaging station .09041500 , Muddy Creek at Kremmling (fig. 1), hereinafter referred to as the Muddy Creek gage. The discharge record for the Muddy Creek gage includes the stream discharge of Muddy Ditch diversion, which is located about $2,000 \mathrm{ft}$ upstream from the gage. The average stream discharge for Muddy Creek gage for October 1982 through September 1987 (water years 1983-87) was $131 \mathrm{ft}^{3} / \mathrm{s}(94,910$ acre-ft/yr). The maximum recorded daily stream discharge was $1,670 \mathrm{ft}^{3} / \mathrm{s}$ in May 1984 . Approximately 78 percent of the stream discharge at Muddy Creek for the period of record occurred during April through June.

An estimate of the longer term stream discharge for Muddy Creek was made using information developed for the water-supply and reservoir-operations study for Wolford Mountain Reservoir (U.S. Forest Service, 1988). That study estimated an average stream discharge of $67,660 \mathrm{acre-ft/yr}$ for the 1961-82 water years. Combining the estimated stream discharge for 1961-82 water years and the measured stream discharge for the 1983-87 water years results in an estimated average stream discharge of $72,710 \mathrm{acre}-\mathrm{ft} / \mathrm{yr}$ (or an average stream discharge of $100 \mathrm{ft}^{3} / \mathrm{s}$ ) for water years $1961-87$.

\section{Acknowledgments}

The author wishes to thank Jim McClure of the Denver Water Department Denver, Colo., and Mick Gordon of the U.S. Bureau of Reclamtion, Loveland, Colo., for supplying data and records for Williams Fork Reservoir and Green Mountain Reservoir. 


\section{WATER TEMPERATURE}

A primary controlling factor of various chemical and biological processes that occur in reservoirs is the vertical temperature distribution of the water. Thermal stratification is a common feature of many temperate-zone lakes and reservoirs during summer, when warmer and less dense water overlies colder and more dense water. The density differences can be large enough to prohibit mixing between water layers, and chemical and biological changes can occur that can cause differences in water quality among the layers. For example, depletion of dissolved oxygen can occur in the hypolimnion because transfer of dissolved oxygen from the surface cannot occur easily. Anaerobic conditions can undesirably affect water quality of the reservoir and of the release water. The temperature profile of the reservoir will determine at which depth inflowing water enters the reservoir. If the inflowing stream water enters the reservoir in the euphotic zone, nutrient supply could be replenished for algal growth. The temperature profile is an important consideration for determining where to place outlets for controlling temperature of the release water. The temperature profile has important implications regarding fishery development and other recreational uses. Thus, estimating the temperature profiles that might be expected in the impounded water is useful to properly design a reservoir.

\section{Description of Temperature Model}

A one-dimensional, time-dependent, mathematical model (Adams, 1974) was used to simulate temperature profiles and outflow temperatures of the proposed Rock Creek and Wolford Mountain Reservoirs. The model can be used for predictive purposes for proposed reservoirs because the data required to use the model would be available prior to contruction of the dam. The reservoir is described as a series of horizontal elements as shown in figure 2 . The assumption is that isotherms in the reservoir are horizontal; hence, thermal gradients are present only in the vertical direction.

The temperature profile produced by the model is the result of conservation of mass and energy within each horizontal element. Stream inflow, solar radiation, atmospheric radiation, vertical advection, and diffusion are primary heat sources; surface evaporation, reservoir releases, diffusion, and back radiation are primary heat losses. The sides and bottom of the reservoir are assumed to be insulated. Mixing by convection occurs in the epilimnion whenever the density gradient is negative (increasing density toward the surface layer). Inflow water enters the water column in the reservoir at the level where the densities of the inflow and reservoir water are the same. Entrance mixing of inflow water is an option in the model and, if used, the mixed inflow temperature is used to determine the density of the inflow water. A number of other, less fundamental aspects of the temperature model are not discussed. For further descriptions of the model, see Huber and Harleman (1968) and Adams (1974).

One initial and two boundary conditions are required by the heat transport equation used in the model. An initial temperature profile of the water body at the beginning of the simulation period is the initial condition. 


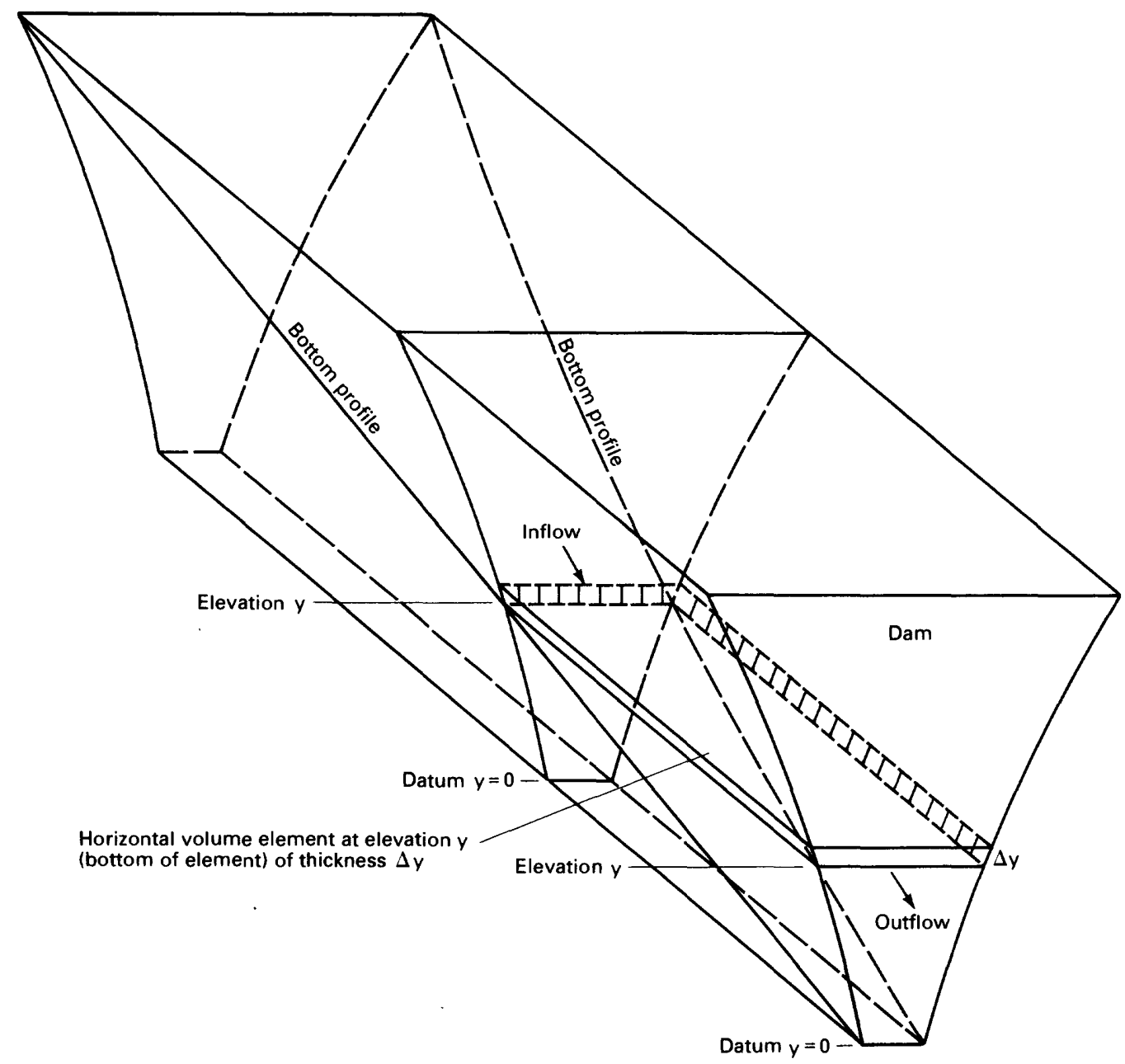

Figure 2.--Schematic three-dimensional view of an idealized reservoir and horizontal volume element used in the temperature model (modified from Adams, 1974). 
The profile can be an assumed isothermal temperature at spring overturn or a measured temperature profile on any date. The boundary conditions are conservation of heat at the water surface and conservation of heat at the reservoir bottom.

The exact mathematical equation used for determining the temperature profile cannot be solved directly (Adams, 1974). The solution is approximated using a finite-element form of the equation. The solution will not be described or derived in this report; see Markofsky and Harleman (1971) and Adams (1974) for further discussion and derivation of the solution.

A FORTRAN computer program was used to compute the finite-element solution of the heat equation. The program is available on the U.S. Geological Survey's computer system. A listing of the program is in Adams (1974) and R.F. Ferreria and D.B. Adams (U.S. Geological Survey, written commun., 1988).

\section{Calibration}

Before the temperature model is used to simulate temperature profiles for proposed reservoirs, it needs to be tested and calibrated using data for existing reservoirs in the study area. Calibration involves adjusting various coefficients in the model until the best match of measured and simulatedtemperature profiles and measured and simulated outflow temperatures are obtained. The reservoirs used for calibration in this study were Williams Fork and Green Mountain Reservoirs, both located near Kremmling (fig. 1). Those reservoirs were selected because they are near the proposed reservoir sites and are in an area with similar physiography and climate. Descriptive data for each reservoir are listed in table 1 . To use the model, the following input data are required:

1. Reservoir geometry data, which include width, length, and area at selected reservoir elevations, and outlet elevation(s).

2. Initial conditions, which include initial temperature profile, number of time steps, length of time step, initial surface elevation, and layer thickness.

Table 1.--Selected descriptive data for Williams Fork and Green Mountain Reservoirs

\begin{tabular}{lcccccc}
\hline Reservoir & $\begin{array}{c}\text { Normal maximum } \\
\text { water-surface } \\
\text { elevation } \\
\text { above sea } \\
\text { level } \\
\text { (feet) }\end{array}$ & $\begin{array}{c}\text { Capacity } \\
\text { (acre- } \\
\text { feet) }\end{array}$ & $\begin{array}{c}\text { Dead } \\
\text { storage } \\
\text { (acre- } \\
\text { feet) }\end{array}$ & $\begin{array}{c}\text { Surface } \\
\text { area } \\
\text { (acres) }\end{array}$ & $\begin{array}{c}\text { Maximum } \\
\text { depth } \\
\text { (feet) }\end{array}$ & $\begin{array}{c}\text { Outlet } \\
\text { elevation } \\
\text { above sea } \\
\text { level } \\
\text { (feet) }\end{array}$ \\
\hline $\begin{array}{l}\text { Williams } \\
\text { Fork }\end{array}$ & 7,810 & 96,820 & 0 & 1,618 & 169 & 7,635 \\
$\begin{array}{c}\text { Green } \\
\text { Mountain }\end{array}$ & 7,950 & 154,660 & 7,760 & 2,124 & 259 & 7,800 \\
\hline
\end{tabular}


3. Inflow stream temperature.

4. Air temperature.

5. Relative humidity.

6. Wind speed.

7. Net solar radiation.

8. Net atmospheric radiation.

9. Reservoir surface elevations.

10. Inflow stream discharge.

11. Outflow discharge.

For best results, average daily values for the period to be simulated should be used for items 3 through 11 . Output from the model includes temperature profiles for selected dates in the simulation period, heat budget terms and values of variables such as withdrawal layer thickness and grid number where the inflow water was placed, and a summary of outflow temperatures for each time step.

For model calibration, six data sets were developed: Williams Fork Reservoir for 1979, 1980, 1986, and 1987, and Green Mountain Reservoir for 1986 and 1987. An evaporation study was done and detailed climatological and temperature-profile data were collected at Williams Fork Reservoir during 1979 and 1980 (Spahr and Ruddy, 1983). All data for items 3 through 9 and temperature profiles for 1979 and 1980 were obtained from N.E. Spahr (U.S. Geological Survey, written commun., 1986). Climatological data (except air temperature) used for Williams Fork and Green Mountain Reservoirs for 1986 were collected at a weather station located near Leal (fig. 1), about $15 \mathrm{mi}$ upstream from gaging station 09037500 (N.E. Spahr, U.S. Geological Survey, written commun., 1987). The operation of the Leal weather station was discontinued in April 1987, necessitating use of another source for climatological data for 1987. The nearest site where climatological data were measured and that was most applicable to the study area was at Rabbit Ears Pass (fig. 1), located about $25 \mathrm{mi}$ northwest of Kremmling at an elevation of 9,300 ft. The climatological data from Rabbit Ears Pass (L.D. Beaver, U.S. Geological Survey, written commun., 1987) was used for the model data sets for 1987 for Williams Fork and Green Mountain Reservoirs. The mean daily air temperatures downstream from the dam of each reservoir (National Oceanic and Atmospheric Administration, 1986, 1987) were used in the input data sets for 1986 and 1987.

Inflow stream discharge and stream temperature into Williams Fork Reservoir were measured at gaging station 09037500, and outflow stream discharge and stream temperature were measured at gaging station 09038500 (fig. 1). Inflow stream discharge and stream temperature into Green Mountain Reservoir were measured at gaging station 09053500 , and outflow stream discharge and stream temperature were measured at gaging station 09057500 (fig. 1). The discharge into Green Mountain Reservoir was adjusted to account for tributary discharge into the reservoir downstream from station 09053500. Reservoir capacity and area data and daily records of reservoir surface elevations were obtained from the Denver Water Department for Williams Fork Reservoir and from the U.S. Bureau of Reclamation for Green Mountain Reservoir. 
The time period used for calibration of the temperature model was May through October (table 2). The beginning date varied among the six calibration periods depending upon when climatological data were collected and temperature profiles were measured. Data were not collected at Williams Fork Reservoir during 1979 and 1980 until the third week of May. The periods selected include the seasonal cycles of the temperature regime from spring overturn through summer stratification to fall overturn. Beginning dates probably were after the spring overturn but preceded the start of distinct thermal layering in the reservoirs. The time period selected did not include periods when there was ice cover because the model is not designed to simulate ice-covered reservoirs. The flushing rate in table 2 is the ratio of the total outflow discharge to the mean reservoir volume during the calibration period. It is a measure of the rate of replacement of water in the reservoir. For example, a flushing rate of 2 indicates that two reservoir volumes were replaced or 'flushed' during the period.

Table 2.--Beginning and ending dates and flushing rates for the calibration periods used in the temperature model for williams Fork and Green Mountain Reservoirs

\begin{tabular}{llllr}
\hline Reservoir & Year & Begin date & End date & Flushing rate \\
\hline Williams & 1979 & May 21 & November 3 & 0.87 \\
Fork & 1980 & May 20 & October 27 & .45 \\
& 1986 & May 1 & October 31 & .72 \\
& 1987 & May 7 & October 31 & .22 \\
Green & 1986 & May 1 & October 31 & 2.45 \\
$\quad$ Mountain & 1987 & May 14 & October 31 & 1.32 \\
\hline
\end{tabular}

Each data set was calibrated independently of other data sets, and model coefficients were adjusted to obtain the best match of measured and simulated temperature profiles and measured and simulated outflow temperatures. This was done to obtain a range of values for model coefficients and to determine which coefficients were the most sensitive in the model. During calibration of the-model it was evident that some coefficients had greater effect on temperature profiles and outflow temperature than other coefficients. The maximum change in temperature caused by varying coefficients over reasonable ranges of values was about $2{ }^{\circ} \mathrm{C}$. The change in temperature profiles caused by changing coefficient values varied with layer depth and time. Temperature of layers near the reservoir bottom and of the outflow were much less sensitive to changes in most model coefficient values than were the upper layers of the temperature profiles. Because the temperature simulations will be used for preliminary planning purposes for proposed reservoirs, potential errors of 3 or $4{ }^{\circ} \mathrm{C}$ were not considered critical; therefore, detailed sensitivity analyses of the model were not considered necessary for inclusion in this report. For a description of model coefficients and detailed description of the input data sets, see Adams (1974) or R.F. Ferreria and D.B. Adams (U.S. Geological Survey, written commun., 1988). 
The range of optimum values of model coefficients obtained during independent calibration of the six data sets were not large except for the coefficient called the mixing ratio. The mixing ratio pertains to the degree of mixing of inflow water and reservoir water at the head of the reservoir. It is the ratio of the volume of reservoir water to the volume of inflow water used for entrance mixing. The mixing ratio can affect the quantity of heat transferred longitudinally in the reservoir in the epilimnion and metalimnion and, during summer, increased values of mixing ratio usually caused increased temperature in the upper and middle layers of the reservoir. The mixing ratio does not directly affect temperature in deep layers, but a small part of the heat added to middle layers gradually was transported by circulation dynamics to the deeper layers during the simulation period. The volume of inflow and outflow discharges (a measure of which is the flushing rate) had substantial effects on circulation dynamics in the temperature model and therefore affected the heat transfer to the deep layers. Apparently, simulation periods that had large flushing rates had greater mixing and faster transfer of heat to the deep layers in the temperature model than did simulation periods that had small flushing rates. For model calibration, the mixing ratio was a function of flushing rate for the simulation period; a simulation period that had a large flushing rate (more mixing) had a smaller value of mixing ratio than a simulation period that had a smaller flushing rate. In addition, the timing of peak inflow and outflow discharges affected mixing by the temperature model. All other model coefficients used for calibrating the individual data sets could be interchanged among the data sets without increasing the model errors by more than about $1^{\circ} \mathrm{C}$. This would be considered verification of the model, if reservoir operations (and use of different values of mixing ratio) were considered.

Measured and simulated temperature profiles for Williams Fork Reservoir (1979, 1980, 1986, and 1987) are shown in figures 3 through 5, and measured and simulated outflow temperatures are shown in figures 6 and 7 . The model simulated seasonal variation and general shape of the temperature profiles reasonably well. The development of the thermoclines in summer and the increases in mixed-layer depth in autumn are quite accurately simulated. The most notable model error is associated with temperature of the deeper layers in the reservoir. For years where outflow was decreased and flushing rates were small (1980 and 1987), the model did not transfer sufficient heat to deeper layers until late in the season. The simulated temperatures in the hypolimnion were about 2 to $3^{\circ} \mathrm{C}$ too cold for much of 1980 and 1987 . A different calibration was used for 1980 and 1987 by increasing the mixing ratio, which caused a small increase in bottom-layer temperatures by late summer. Increasing the mixing ratio increased heat input to the middle layers of the reservoir and caused the simulated temperature profiles to be too warm in the metalimnion. For example, the simulated temperatures in the metalimnion were 2 to $2.5^{\circ} \mathrm{C}$ too warm for the August 19, 1987, profile. Because Williams Fork Reservoir is a bottom-withdrawal reservoir, errors in simulated outflow temperatures will parallel model errors in the temperature profile in the deeper layers. Generally, the simulated outflow temperatures were too cool compared to the measured outflow temperatures. Maximum error for simulated outflow temperatures was about $3.5^{\circ} \mathrm{C}$ too cold for July and August of 1980 . 


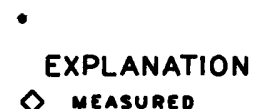

8 measureo
$\nabla$ simulateo
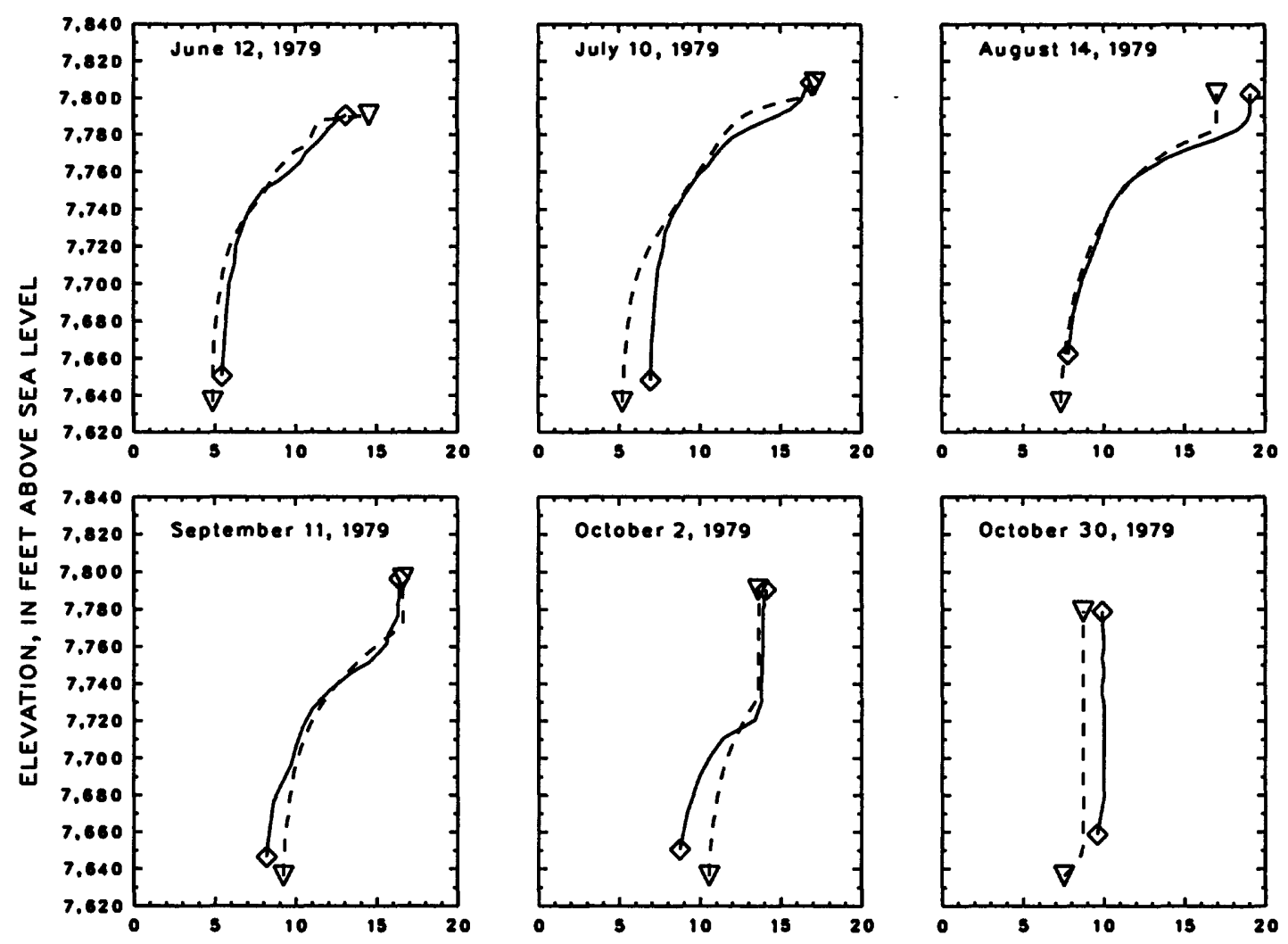

WATER TEMPERATURE, IN DEGREES CELSIUS

Figure 3.--Measured and simulated temperature profiles for Williams Fork Reservoir, 1979. 
EXPLANATION

$\Delta$ measureo
$\mathbf{V}$ simulateo
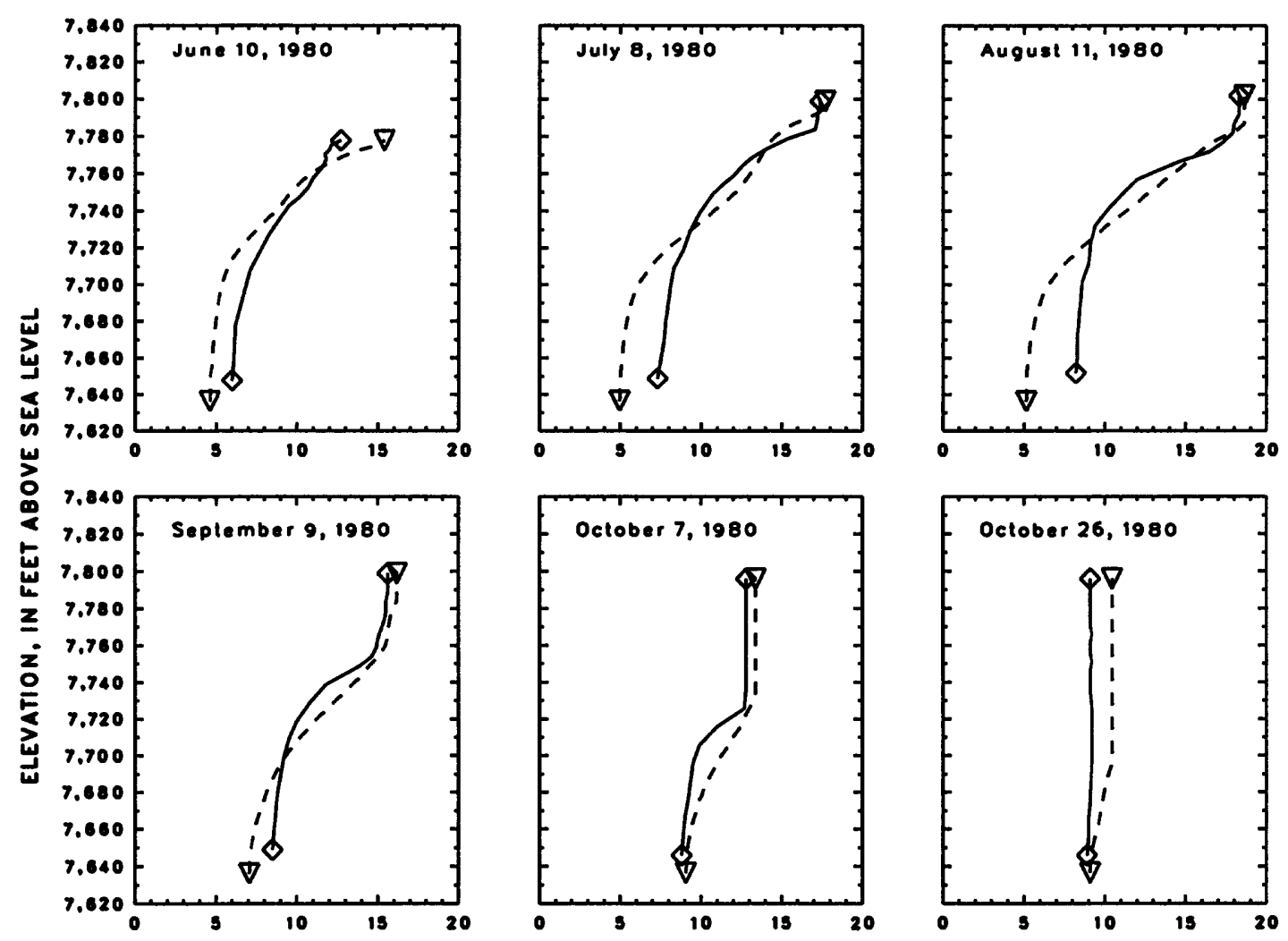

WATER TEMPERATURE, IN DEGREES CELSIUS

Figure 4.--Measured and simulated temperature profiles for Williams Fork Reservoir, 1980. 

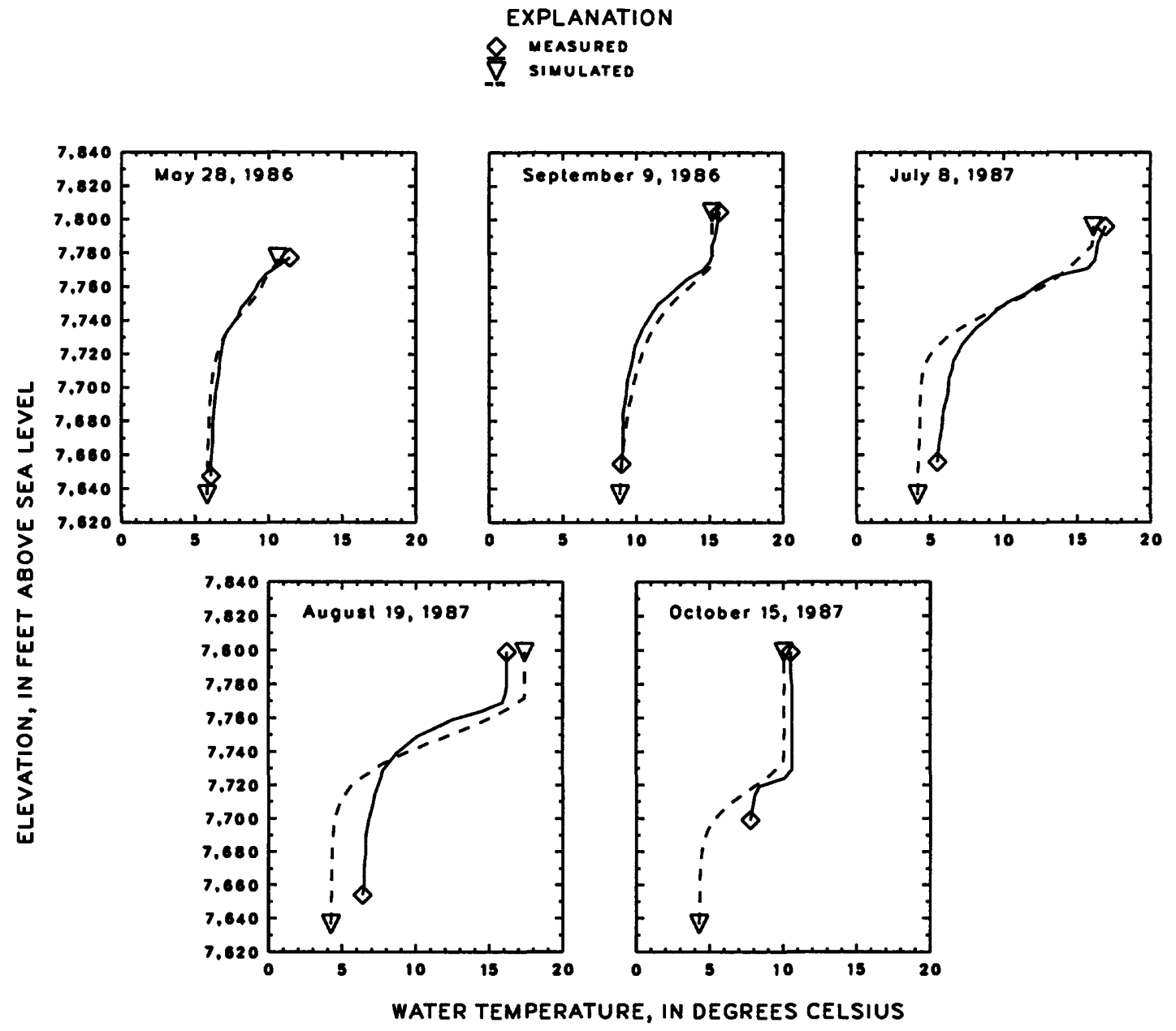

Figure 5.--Measured and simulated temperature profiles for Williams Fork Reservoir, 1986-87. 


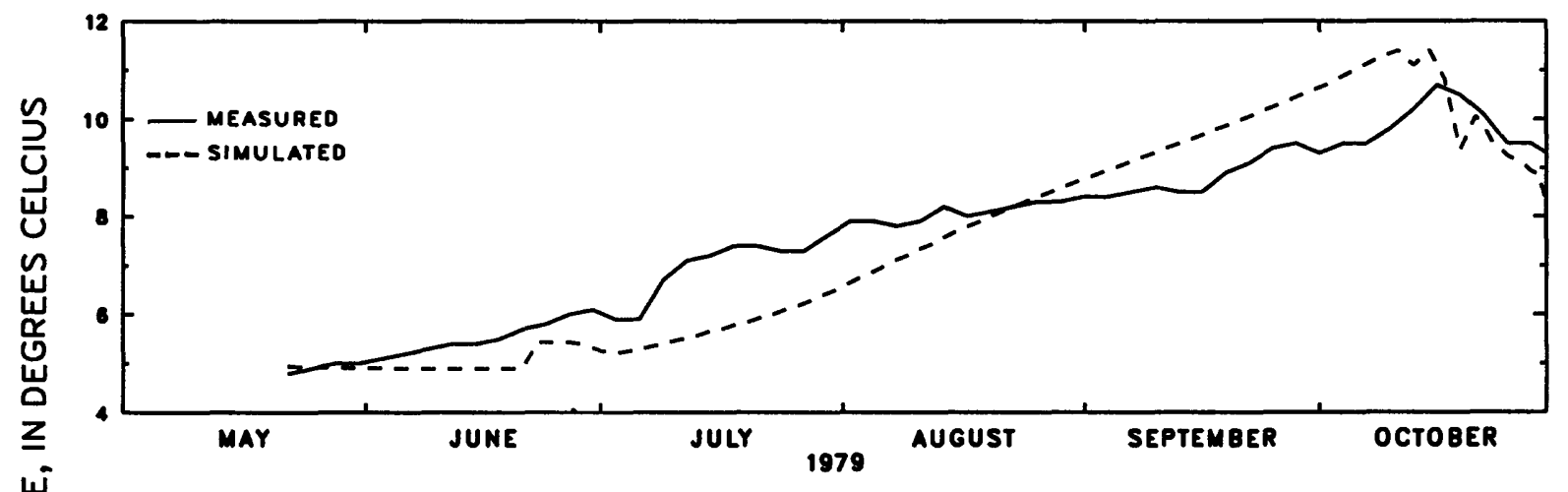

㭊

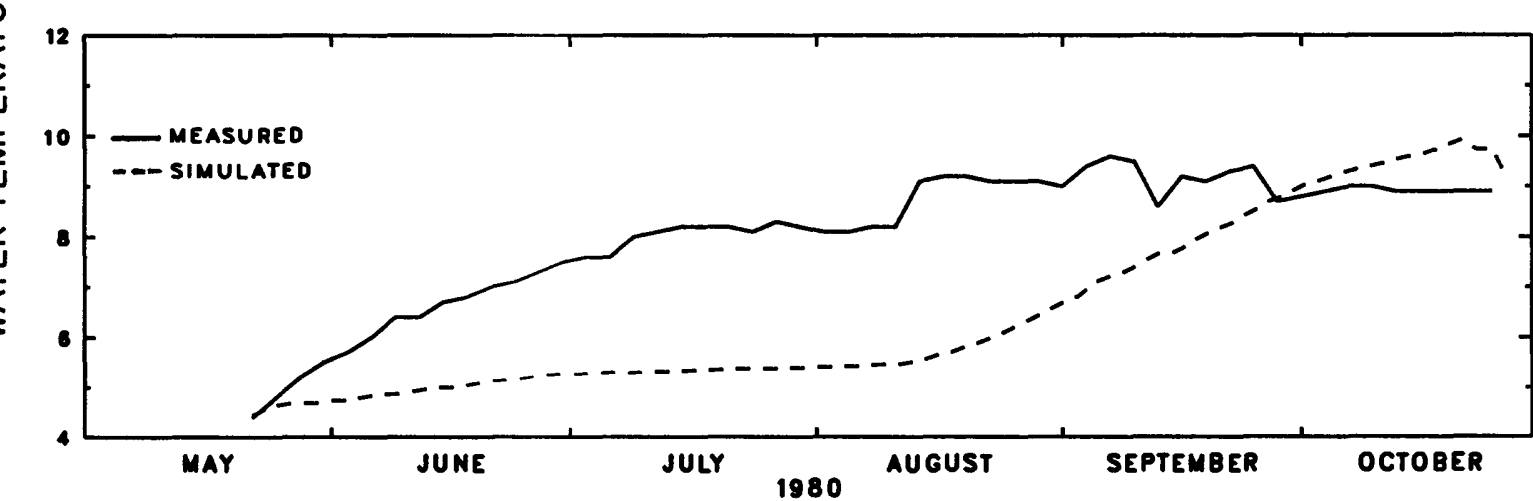

Figure 6.--Measured and simulated temperatures of outflow from Williams Fork Reservoir, 1979-80. 

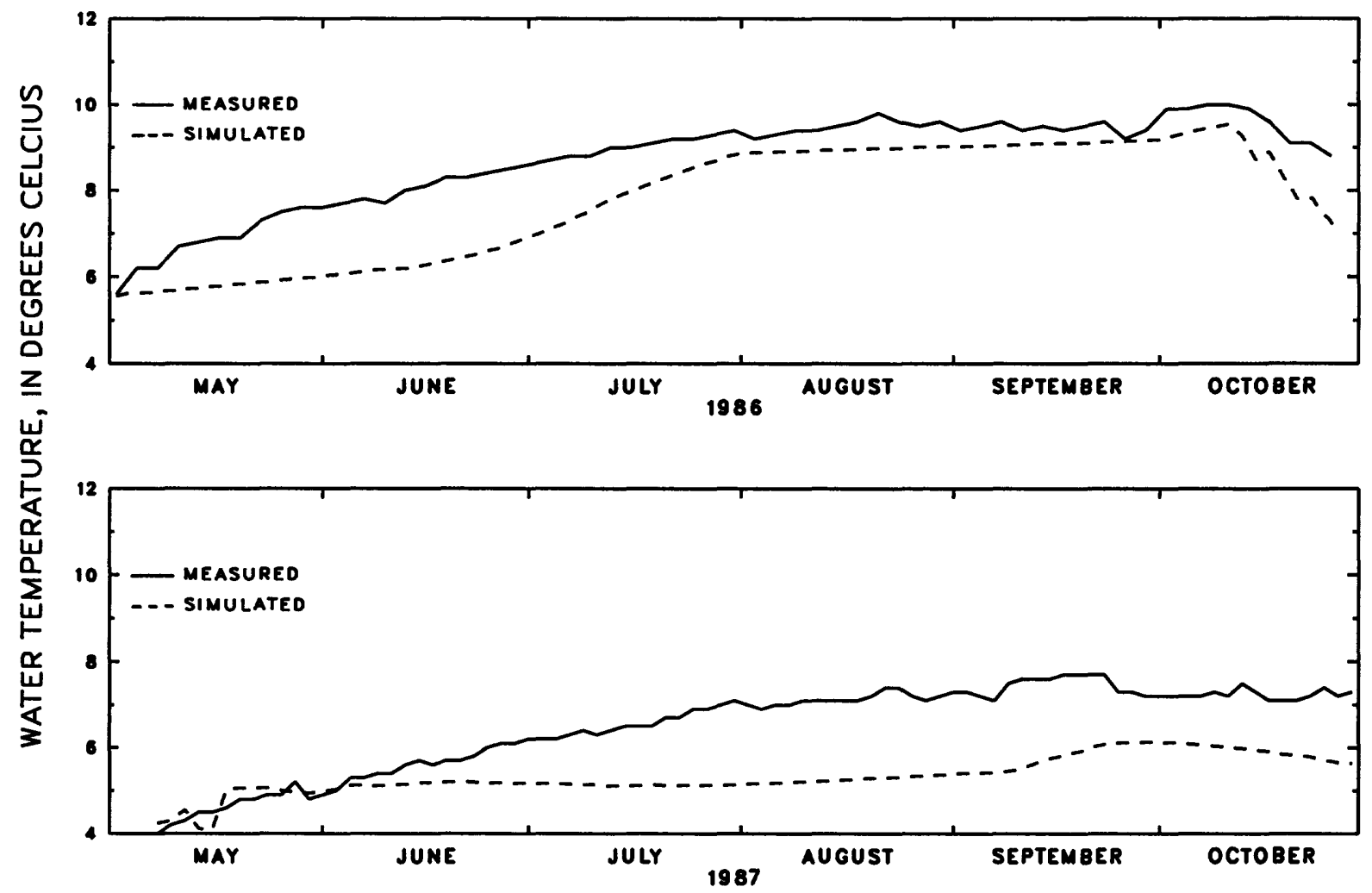

Figure 7.--Measured and simulated temperatures of outflow from Williams Fork Reservoir, 1986-87. 
Measured and simulated temperature profiles for Green Mountain Reservoir (1986 and 1987) are shown in figure 8, and measured and simulated outflow temperatures are shown in figure 9. Temperature model errors generally were less for Green Mountain Reservoir than for Williams Fork Reservoir. Flushing rates for the two calibration periods for Green Mountain Reservoir were considerably larger than for Williams Fork Reservoir, which implies that more mixing occurred in Green Mountain Reservoir, at least to the level of the outlet $(7,800 \mathrm{ft})$. The largest errors in the simulated profiles usually were for the deepest measured layers. The simulated profiles for 1986 and 1987 generally matched the measured temperatures within $2{ }^{\circ} \mathrm{C}$ to about the $7,775-\mathrm{ft}$ elevation. Temperature in the deepest layers was not measured because of equipment limitations. The largest known error for simulated temperature profiles was $3{ }^{\circ} \mathrm{C}$ too cold for the $7,750-\mathrm{ft}$ layer on August 18, 1987. The model simulated the outflow temperature more accurately for Green Mountain Reservoir because the outlet is $100 \mathrm{ft}$ above the bottom of Green Mountain Reservoir, whereas the outlet is at the bottom of Williams Fork Reservoir. The simulated outflow temperatures (fig. 9) usually were within $1.5^{\circ} \mathrm{C}$ of the measured outflow temperatures.

In summary, the temperature model had maximum errors of about $3.5{ }^{\circ} \mathrm{C}$ at the reservoir bottom for temperature profiles and for outflow temperatures based on the calibration results of six data sets for the two reservoirs. The maximum errors for temperature profiles were for the deep water layers; apparently the temperature model did not transfer sufficient heat to the water layers near the bottom. Simulated temperatures in bottom layers were as much as $3{ }^{\circ} \mathrm{C}$ too cold. The model seems to accurately track the seasonal change in the temperature profiles. More error occurred in simulation of outflow temperature where the outlet was at the bottom of the reservoir. Simulated outflow temperatures for a bottom-withdrawal reservoir probably would be too cold. That conclusion may be different for a bottom-withdrawal reservoir if a large outflow discharge occurs relative to reservoir storage during summer, as indicated by the calibration results for Williams Fork Reservoir for 1979 .

\section{Simulation}

Simulation involved applying the calibrated temperature model to the proposed Rock Creek and Wolford Mountain Reservoirs. Four different years were simulated for each site to include normal, greater than normal, and less than normal runoff years. The period from May through October was simulated. Simulated reservoir operations were based on water-supply studies for Rock Creek Reservoir (Western Engineers, Inc., 1984), Wolford Mountain Reservoir (Western Engineers, Inc., 1983), and on information in the Supplemental Draft Environmental Impact Statement (U.S. Forest Service, 1988). Reservoir geometry data were obtained from the same sources listed above. Reservoir data are listed in table 3 . The daily average solar radiation, atmospheric radiation, wind speed, and relative humidity for 1985 and 1986 at the Leal weather station were used for the input climate data. 
EXPLANATION

$\underline{\nabla}$ MEASUREO

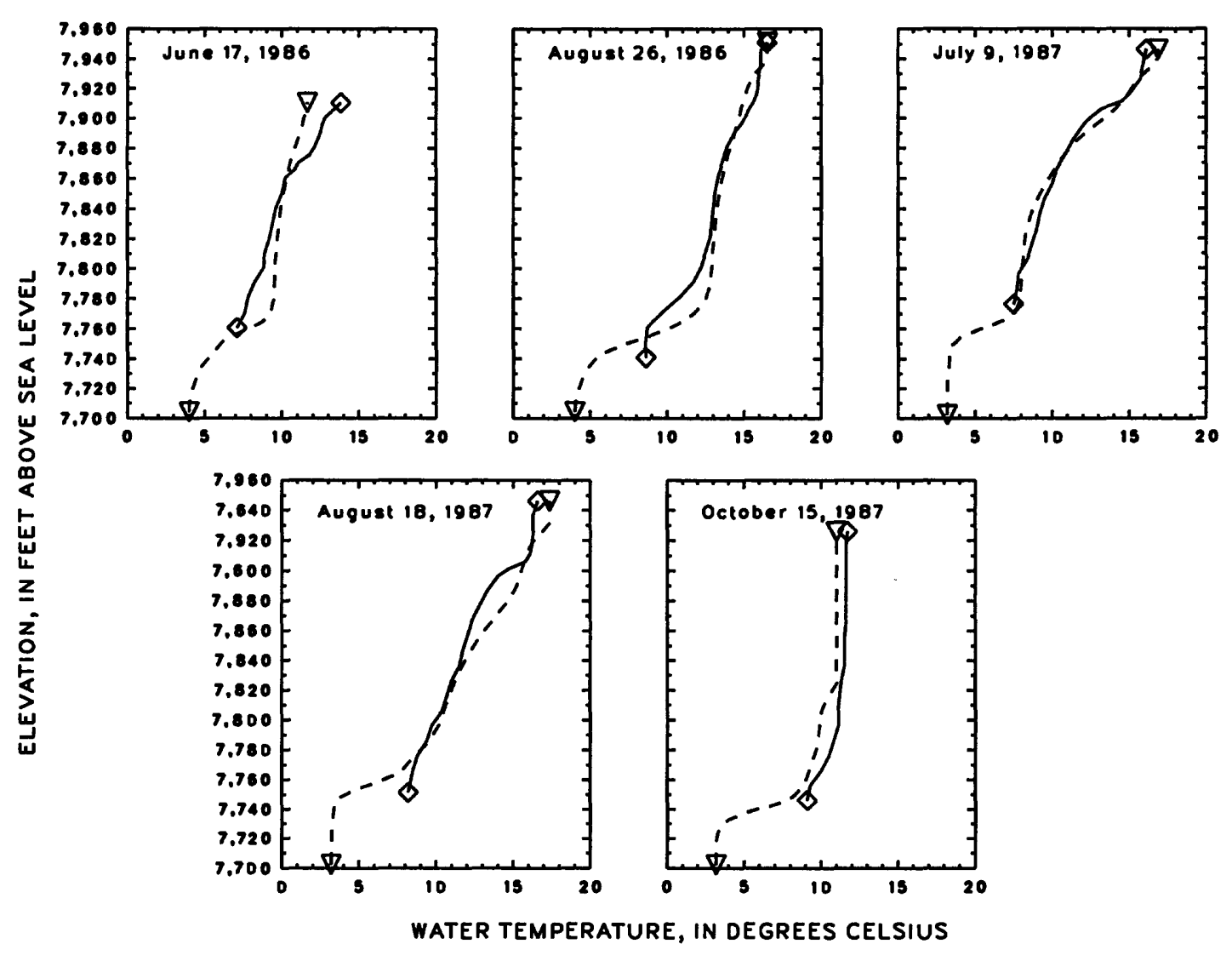

Figure 8.--Measured and simulated temperature profiles for Green Mountain Reservoir, 1986-87. 


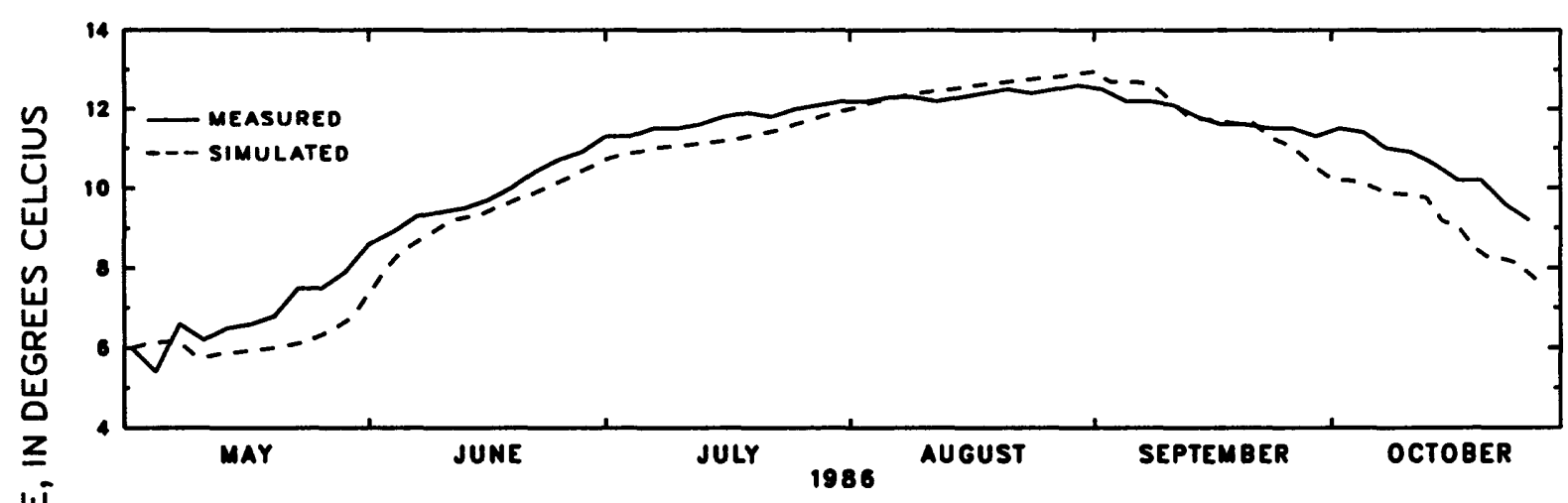

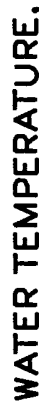

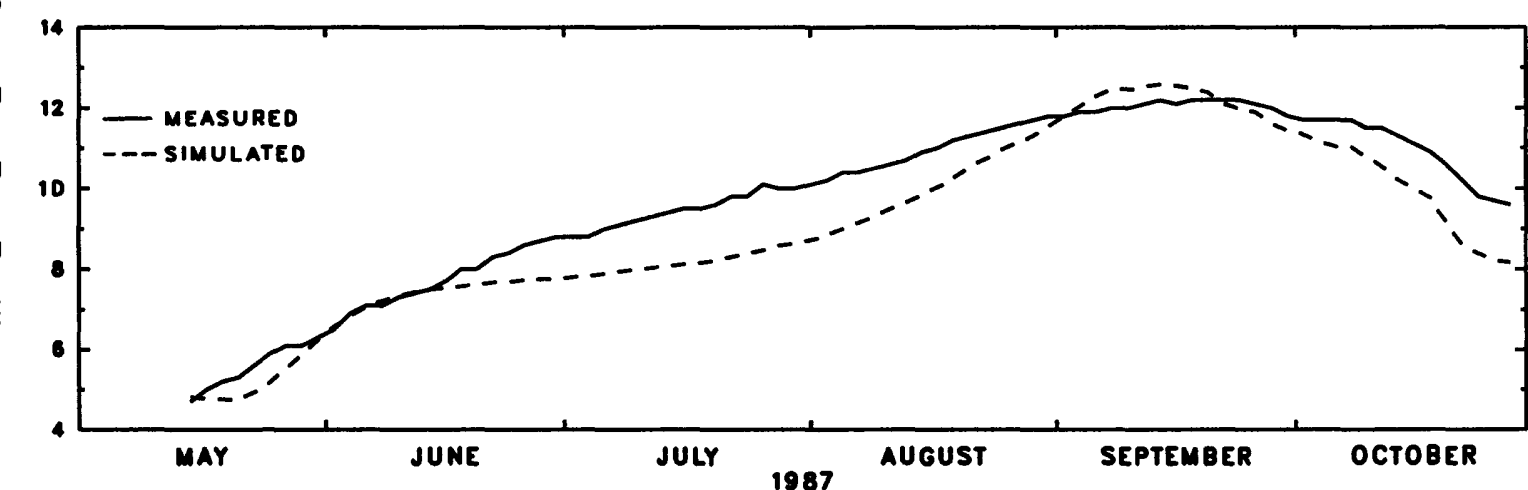

Figure 9.--Measured and simulated temperatures of outflow from Green Mountain Reservoir, 1986-87. 
Table 3.--Selected descriptive data for the proposed Rock Creek and Wolford Mountain Reservoirs

\begin{tabular}{lcccccc}
\hline Reservoir & $\begin{array}{c}\text { Normal maximum } \\
\text { water-surface } \\
\text { elevation } \\
\text { above sea } \\
\text { level } \\
\text { (feet) }\end{array}$ & $\begin{array}{c}\text { Capacity } \\
\text { (acre- } \\
\text { feet) }\end{array}$ & $\begin{array}{c}\text { Dead } \\
\text { storage } \\
\text { (acre- } \\
\text { feet) }\end{array}$ & $\begin{array}{c}\text { Surface } \\
\text { area } \\
\text { (acres) }\end{array}$ & $\begin{array}{c}\text { Maximum } \\
\text { depth } \\
\text { (feet) }\end{array}$ & $\begin{array}{c}\text { Outlet } \\
\text { elevation } \\
\text { above sea } \\
\text { level } \\
\text { (feet) }\end{array}$ \\
\hline $\begin{array}{l}\text { Rock } \\
\text { Creek }\end{array}$ & 8,681 & 50,700 & 500 & 1,069 & 163 & 8,554 \\
$\begin{array}{l}\text { Wolford } \\
\text { Mountain }\end{array}$ & 7,485 & 60,000 & $(1)$ & 1,447 & 110 & $(1)$ \\
\hline
\end{tabular}

12,999 acre-feet dead storage for outlet elevation 7,410 feet; 6,085 acre-feet dead storage for outlet elevation 7,420 feet; 16,222 acre-feet dead storage for outlet elevation 7,440 feet.

\section{Rock Creek Reservoir}

Temperature profiles were simulated for the Rock Creek Reservoir for 1957, 1962, 1972, and 1977. The largest annual discharges for the period of discharge record at the Toponas gage (water years 1953-80) was in 1957 and 1962. The effects of the timing of runoff were examined by simulating 1957 and 1962. A late runoff occurred in 1957, and an early runoff occurred in 1962. The simulation of 1972 represents a normal runoff year, and the simulation of 1977 represents a less than normal runoff year. A summary of monthly inflow and outflow discharges and reservoir storage for the simulation periods is listed in table 4. The inflow discharge was computed by multiplying the discharge of Rock Creek at the Toponas gage by 1.095. The factor was used to account for stream discharge from Horse Creek (fig. 1) and assumes that runoff yield per unit drainage-basin area for Horse Creek is the same as for Rock Creek upstream from the Toponas gage. The inflow stream temperatures were simulated from a harmonic regression equation that incorporates stream discharge. The regression equation was developed from mean daily stream temperatures recorded at the Crater gage in 1986 and 1987. Air temperatures at Grand Lake (National Oceanic and Atmospheric Administration, 1957, 1962, 1972, and 1977), located about $44 \mathrm{mi}$ northeast of the reservoir site, were used for the air temperatures for Rock Creek Reservoir. The elevation of Grand Lake nearly is the same as the Rock Creek Reservoir site; hence, average air temperatures between the two locations likely are similar.

The values of model coefficients determined from the calibration runs were used for simulation. For coefficients that had small differences of values among the calibration runs, average values were used. The mixing ratio used for simulation was based on comparison of flushing rates for Rock Creek Reservoir (table 5) to the flushing rates of the calibration reservoirs. 
Table 4.--Simulated monthly inflow and outflow discharges and reservoir storage for Rock Creek Reservoir, April through October, 1957, 1962, 1972, and 1977

[A11 values in acre-feet]

\begin{tabular}{|c|c|c|c|c|}
\hline Month & Inflow & Outflow & $\begin{array}{l}\text { Reservoir storage } \\
\text { at end of month }\end{array}$ & $\begin{array}{l}\text { Change in storage } \\
\text { during month }\end{array}$ \\
\hline \multicolumn{5}{|c|}{1957} \\
\hline $\begin{array}{l}\text { April } \\
\text { May } \\
\text { June } \\
\text { July } \\
\text { August } \\
\text { September } \\
\text { October }\end{array}$ & $\begin{array}{r}1,497 \\
10,931 \\
19,459 \\
4,177 \\
1,139 \\
717 \\
880\end{array}$ & $\begin{array}{r}2,120 \\
984 \\
8,889 \\
4,177 \\
1,139 \\
2,640 \\
3,500\end{array}$ & $\begin{array}{l}30,084 \\
40,031 \\
50,601 \\
50,601 \\
50,601 \\
48,678 \\
46,058\end{array}$ & $\begin{array}{r}-623 \\
9,947 \\
10,570 \\
0 \\
0 \\
-1,923 \\
-2,620\end{array}$ \\
\hline \multicolumn{5}{|c|}{1962} \\
\hline $\begin{array}{l}\text { April } \\
\text { May } \\
\text { June } \\
\text { July } \\
\text { August } \\
\text { September } \\
\text { October }\end{array}$ & $\begin{array}{r}10,458 \\
18,615 \\
8,983 \\
1,795 \\
647 \\
526 \\
695\end{array}$ & $\begin{array}{r}800 \\
15,576 \\
8,983 \\
1,795 \\
3,821 \\
3,747 \\
1,768\end{array}$ & $\begin{array}{l}47,561 \\
50,600 \\
50,600 \\
50,600 \\
47,426 \\
44,205 \\
43,132\end{array}$ & $\begin{array}{r}9,658 \\
3,039 \\
0 \\
0 \\
-3,174 \\
-3,221 \\
-1,073\end{array}$ \\
\hline \multicolumn{5}{|c|}{1972} \\
\hline $\begin{array}{l}\text { April } \\
\text { May } \\
\text { June } \\
\text { July } \\
\text { August } \\
\text { September } \\
\text { October }\end{array}$ & $\begin{array}{r}3,603 \\
9,460 \\
6,595 \\
943 \\
533 \\
750 \\
1,000\end{array}$ & $\begin{array}{r}7,400 \\
900 \\
4,626 \\
4,390 \\
5,300 \\
5,400 \\
5,000\end{array}$ & $\begin{array}{l}39,871 \\
48,431 \\
50,400 \\
46,953 \\
42,186 \\
37,536 \\
33,536\end{array}$ & $\begin{array}{r}-3,797 \\
8,560 \\
1,969 \\
-3,447 \\
-4,767 \\
-4,650 \\
-4,000\end{array}$ \\
\hline \multicolumn{5}{|c|}{1977} \\
\hline $\begin{array}{l}\text { April } \\
\text { May } \\
\text { June } \\
\text { July } \\
\text { August } \\
\text { September } \\
\text { October }\end{array}$ & $\begin{array}{r}1,584 \\
3,065 \\
775 \\
668 \\
665 \\
480 \\
682\end{array}$ & $\begin{array}{r}1,786 \\
3,260 \\
952 \\
12,424 \\
18,144 \\
2,500 \\
1,845\end{array}$ & $\begin{array}{r}42,641 \\
42,446 \\
42,269 \\
30,513 \\
13,034 \\
11,014 \\
9,851\end{array}$ & $\begin{array}{r}-202 \\
-195 \\
-177 \\
-11,756 \\
-17,479 \\
-2,020 \\
-1,163\end{array}$ \\
\hline
\end{tabular}


Table 5.--Flushing rate of simulation periods for

Rock Creek and Wolford Mountain Reservoirs

[Flushing rates are for the period May through

October for each year simulated]

\begin{tabular}{lcc}
\hline Reservoir & Year & Flushing rate \\
\hline Rock Creek & 1957 & 0.46 \\
& 1962 & .74 \\
& 1972 & .60 \\
& 1977 & 1.43 \\
Wolford & 1976 & .74 \\
Mountain & 1977 & 1.02 \\
& 1984 & 1.94 \\
& 1987 & .67 \\
\hline
\end{tabular}

Ideally, the climatological data for input into the temperature model need to be collected at the reservoir sites, but such a comprehensive datacollection program was not possible for this study. The differences in climatological variables such as solar radiation and wind speed between the Leal weather station and the Rock Creek Reservoir site were not known. Air temperature, relative humidity, wind speed, solar radiation, and atmospheric radiation are important variables that are used to compute the energy budget at the water surface in the temperature model. Consequently, errors in the values of those variables can cause errors in the temperature simulations derived from the model. Simulated profiles would indicate warmer temperatures if an increase in solar or atmospheric radiation (more heat) were input or if a decrease in wind speed or an increase in relative humidity (less evaporative heat loss) were input. Simulated profiles would indicate colder temperatures if a decrease in solar or atmospheric radiation (less heat) were input or if an increase in wind speed or a decrease in relative humidity (more evaporative heat loss) were input. The maximum change in temperature profiles caused by reasonable changes in values of climatological variables was less than $1{ }^{\circ} \mathrm{C}$. For example, an increase in daily solar radiation by 10 percent warmed the epilimnion by $0.9^{\circ} \mathrm{C}$ for the 1972 simulation period. The metalimnion was shifted slightly higher and was about 0.6 to $0.9{ }^{\circ} \mathrm{C}$ warmer than the metalimnion from the initial simulation for 1972. Temperature changes in the hypolimnion and outflow were minimal; an increase of only $0.2^{\circ} \mathrm{C}$ occurred by September. Decreasing the daily solar radiation by 10 percent had the opposite effects as given above; however, magnitude remained about the same. Increasing the relative humidity by 10 percent had a similar effect on the temperature profile as increasing solar radiation by 10 percent. The temperature model did not run successfully if daily relative humidity was decreased by 10 percent or wind speed was increased by 20 percent. Apparently, such changes caused too much surface heat loss and created instabilities in the temperature profile that may have caused violation of stability criteria in the model. Substantially changing the values of climatological variables that cause a large increase in evaporative heat loss probably requires adjustments to certain model coefficients. 
Simulated temperature profiles for the 4 years listed previously are shown in figures 10 and 11. Six profiles are shown for each year. The maximum surface temperatures occurred during August and are about $17{ }^{\circ} \mathrm{C}$. Not much variation occurred in surface temperatures between years because the same climatological data (except air temperature) were used for all years. Actual surface temperatures would vary from year to year depending on summer weather conditions. Temperature profiles for most years probably would be similar to the profiles shown for 1972 (normal year). Temperature simulations indicate that a larger temperature gradient developed in the metalimnion for 1972 compared to 1957 and to 1962. The large inflow of relatively cold water in 1957 and 1962 seems to have impeded development of thermal stratification. The effect of the timing of spring runoff is shown by comparison of temperature profiles for 1957 and 1962. On the basis of simulated reservoir operations, Rock Creek Reservoir would nearly be filled by early May in 1962 but would not be filled until June in 1957 when runoff was much later (table 4). The result was earlier development of thermal stratification (compare July 1 of both years) in 1962 and a slightly larger temperature gradient in the metalimnion in 1962 compared to 1957. Thermal stratification began to diminish by September as the reservoir cooled rapidly. The high elevation of the reservoir site resulted in early cooling. The reservoir was nearly isothermal by the end of 0ctober.

The temperature simulation for Rock Creek Reservoir for 1977 produced different results compared to 1957, 1962, or 1972. Reservoir storage was greatly decreased by late summer to simulate downstream water demands in a drought year (table 4), and the large outflow relative to the decreased reservoir storage (greater flushing rate) induced more heat transfer by the model into deeper layers. Thermal stratification developed early, as indicated by the profile for June 1, 1977. The rapid transfer of heat to deeper layers caused the reservoir water to be nearly mixed by the end of August.

Simulated inflow and outflow temperatures are shown in figures 12 and 13 . Because the outlet is $34 \mathrm{ft}$ above the bottom of the reservoir, the simulated outflow temperatures likely are reasonable estimates of expected outflow temperatures for Rock Creek Reservoir based on calibration results of outflow temperatures for Green Mountain Reservoir. Outflow temperatures generally were 5 to $8{ }^{\circ} \mathrm{C}$; midsummer temperatures in Rock Creek downstream from the dam would be colder than inflow temperatures. Mean daily stream temperatures at the Crater gage in 1986 and 1987 were about 12 to $14{ }^{\circ} \mathrm{C}$ during midsummer. The maximum outflow temperature simulated for 1957 and 1972 was about $8{ }^{\circ} \mathrm{C}$ and occurred in late October. The maximum outflow temperature simulated for 1962 was about $7{ }^{\circ} \mathrm{C}$ and averaged about 0.5 to $1.0^{\circ} \mathrm{C}$ cooler than outflow temperatures for 1957 and 1972. If potential model errors are considered, the outflow temperatures for 1957, 1962, and 1972 essentially are equal. During less than normal runoff years, the outflow may be warmer if reservoir storage was substantially decreased because of greater heat transfer to the outlet withdrawal layers. The simulation for 1977 indicated an appreciable increase in outflow temperatures in August and September; a maximum outflow temperature was about 15 to $16^{\circ} \mathrm{C}$ in late August. The small reservoir storage also enabled rapid cooling during fall, and the simulated outflow temperature decreased to $8{ }^{\circ} \mathrm{C}$ by the end of October 1977 . 

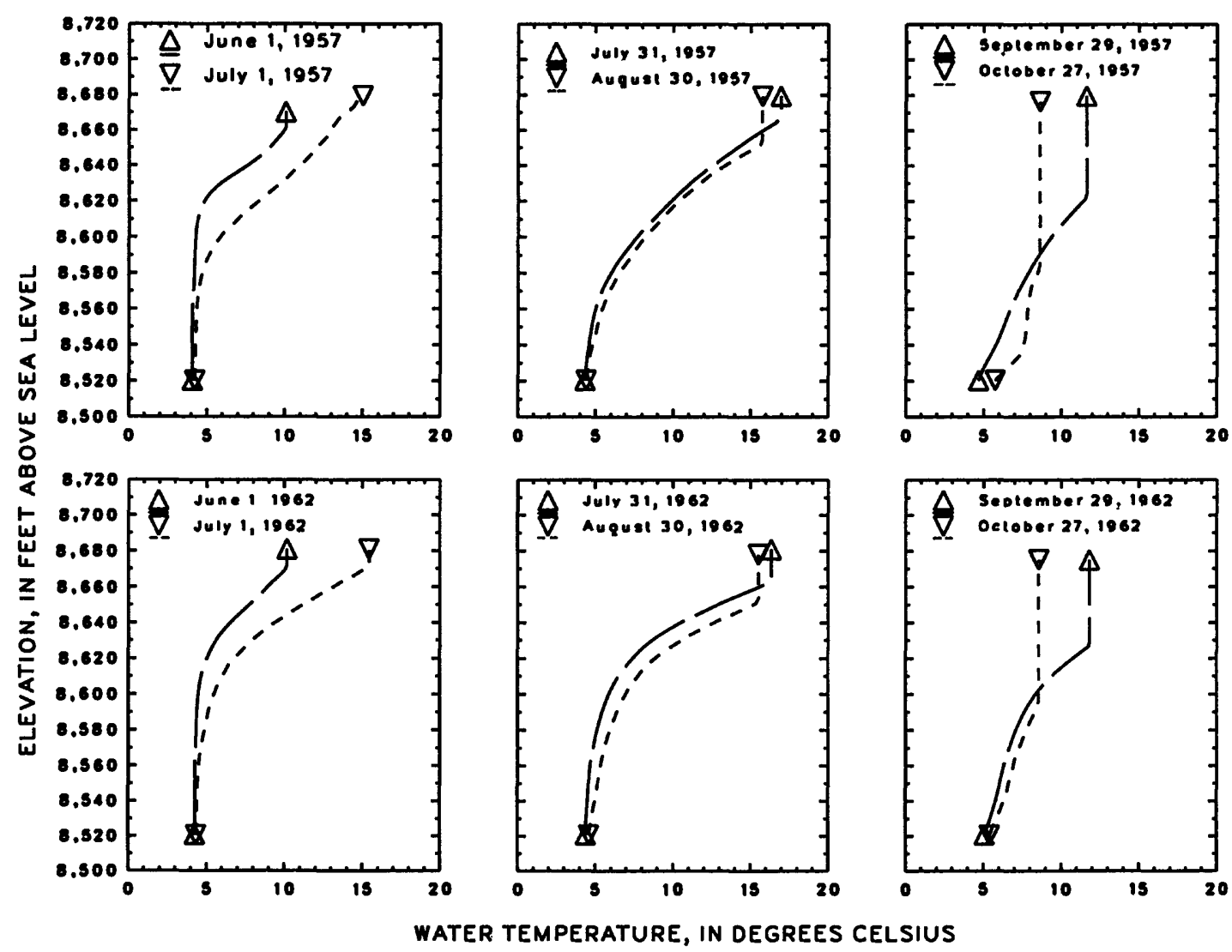

Figure 10.--Simulated temperature profiles for Rock Creek Reservoir, 1957 and 1962. 

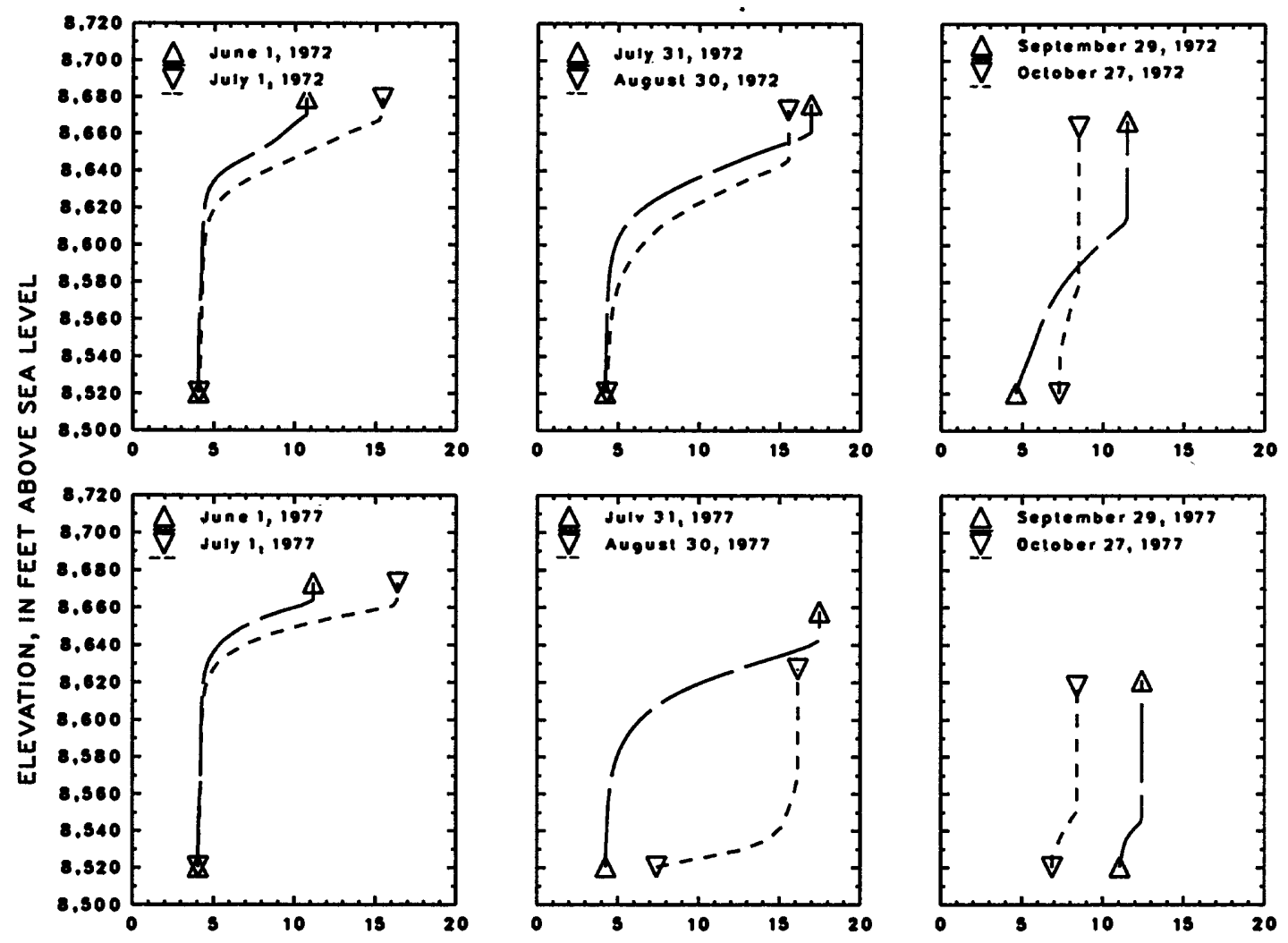

WATER TEMPERATURE, IN DEGREES CELSIUS

Figure 11.--Simulated temperature profiles for Rock Creek Reservoir, 1972 and 1977. 

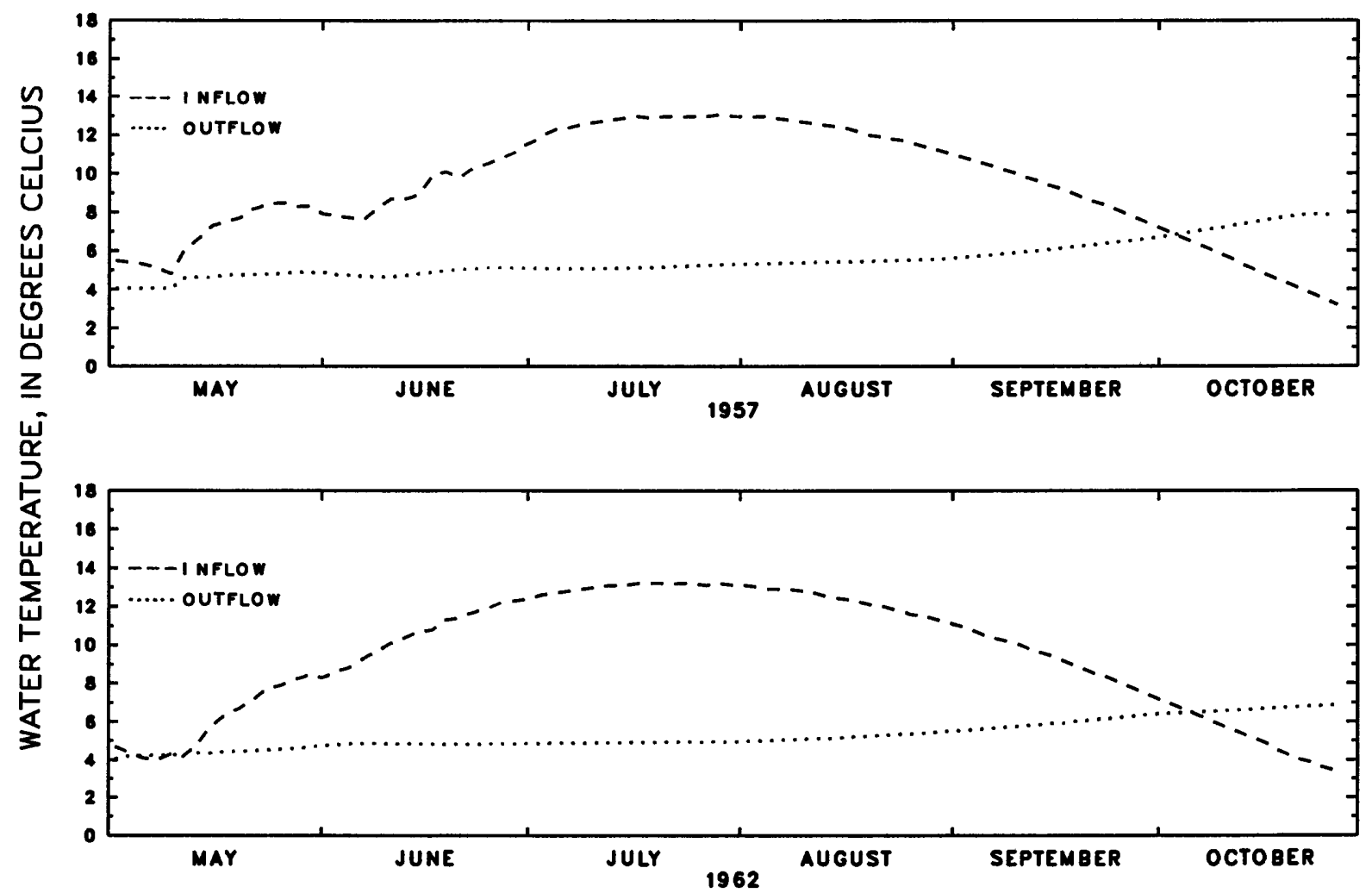

Figure 12.--Simulated inflow and outflow temperatures for Rock Creek Reservoir, 1957 and 1962. 

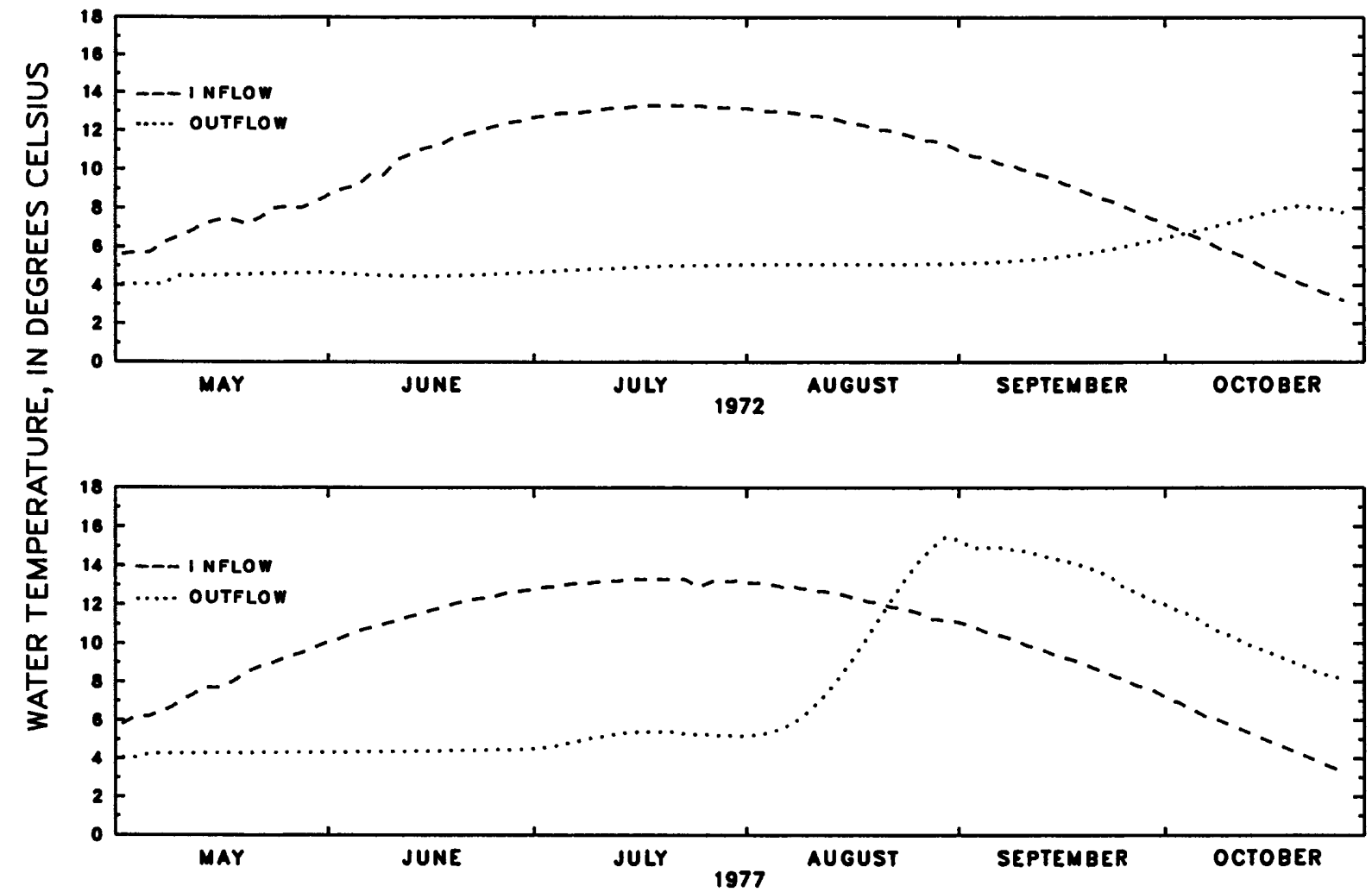

Figure 13.--Simulated inflow and outflow temperatures for Rock Creek Reservoir, 1972 and 1977. 


\section{Wolford Mountain Reservoir}

Temperature profiles were simulated for Wolford Mountain Reservoir for a normal runoff year (1976), less than normal runoff years (1977 and 1987), and a greater than normal runoff year (1984). The primary reason for simulating a second dry year (1987) was to simulate a dry year that had considerably more reservoir storage than was simulated for 1977. Also, actual stream-discharge and stream-temperature data could be used for the temperature simulation of 1987. Inflow-stream discharge for 1976 and 1977 was simulated using the monthly discharges given in the reservoir operations summary of the Supplemental Draft Environmental Impact Statement (U.S. Forest Service, 1988). The inflow discharges for 1984 and 1987 were the stream discharges recorded at the Muddy Creek gage. A summary of monthly inflow and outflow discharges and reservoir storage is listed in table 6 . The same daily values for climatological data (except air temperature) used for temperature simulations for Rock Creek Reservoir also were used for temperature simulations for Wolford Mountain Reservoir. Air temperatures measured at Kremmling (National Oceanic and Atmospheric Administration, 1976, 1977, 1984, and 1987) were used for model input for Wolford Mountain Reservoir. The inflow stream temperatures were simulated for 1976, 1977, and 1984 using a harmonic regression equation that incorporates stream discharge. The inflow stream temperatures used for 1987 were mean daily stream temperatures recorded at the Muddy Creek gage.

Because of possible interest in developing a cold-water fishery downstream from the proposed reservoir, the Colorado River Water Conservation District needed to evaluate the effect of different outlet elevations on outflow temperature. Outlet levels at 7,410, 7,420, and 7,440 ft were simulated. Separate temperature simulations were done for each outlet elevation for each year simulated. Simulation of withdrawal from multiple outlets, which involves using two or more outlets during a simulation period, was not done for this study.

Values of model coefficients used for temperature simulations for Wolford Mountain Reservoir were the same values of model coefficients used for temperature simulations for Rock Creek Reservoir except for the mixing ratio. The mixing ratio used for the simulations for Wolford Mountain Reservoir was based on comparison of the flushing rates for Wolford Mountain Reservoir (table 5) to flushing rates of the calibration reservoirs (table 2).

The temperature profiles for each year simulated at each outlet elevation are shown in figures 14 through 17 . Maximum surface temperatures simulated at Wolford Mountain Reservoir are about $19{ }^{\circ} \mathrm{C}$. That temperature is comparable to midsummer surface temperatures measured at Williams Fork Reservoir (1979, 1980, 1986, and 1987) and Green Mountain Reservoir (1986 and 1987). Simulated surface temperatures will be independent of outlet elevation, because the surface temperature primarily is a function of the energy budget at the water surface. More year-to-year variation of surface temperatures would occur than indicated by the simulation results. The simulation data sets had the same climatological data (except air temperature) for each year. 
Table 6.--Simulated monthly inflow and outflow discharges and reservoir storage for Wolford Mountain Reservoir, April through October, for 1976, 1977, 1984, and 1987

[A11 values in acre-feet]

\begin{tabular}{llcc}
\hline Month Inflow $\quad$ Outflow & $\begin{array}{c}\text { Reservoir storage } \\
\text { at end of month }\end{array}$ & $\begin{array}{c}\text { Change in storage } \\
\text { during month }\end{array}$ \\
\hline
\end{tabular}

\begin{tabular}{|c|c|c|c|c|}
\hline \multicolumn{5}{|c|}{1976} \\
\hline $\begin{array}{l}\text { April } \\
\text { May } \\
\text { June } \\
\text { July } \\
\text { August } \\
\text { September } \\
\text { October }\end{array}$ & $\begin{array}{r}7,723 \\
17,959 \\
7,856 \\
3,444 \\
3,321 \\
1,845 \\
2,399\end{array}$ & $\begin{array}{r}7,976 \\
14,638 \\
7,856 \\
6,150 \\
6,027 \\
2,083 \\
2,645\end{array}$ & $\begin{array}{l}52,069 \\
56,390 \\
56,390 \\
53,684 \\
50,978 \\
50,740 \\
50,494\end{array}$ & $\begin{array}{r}-253 \\
3,321 \\
0 \\
-2,706 \\
-2,706 \\
-238 \\
-246\end{array}$ \\
\hline \multicolumn{5}{|c|}{1977} \\
\hline $\begin{array}{l}\text { April } \\
\text { May } \\
\text { June } \\
\text { July } \\
\text { August } \\
\text { September } \\
\text { October }\end{array}$ & $\begin{array}{r}1,607 \\
3,075 \\
774 \\
677 \\
677 \\
476 \\
677\end{array}$ & $\begin{array}{r}1,786 \\
3,260 \\
952 \\
12,547 \\
18,451 \\
2,559 \\
2,153\end{array}$ & $\begin{array}{l}54,405 \\
54,220 \\
54,042 \\
42,172 \\
24,398 \\
22,315 \\
20,839\end{array}$ & $\begin{array}{r}-179 \\
-185 \\
-178 \\
-11,870 \\
-17,774 \\
-2,083 \\
-1,476\end{array}$ \\
\hline \multicolumn{5}{|c|}{1984} \\
\hline $\begin{array}{l}\text { April } \\
\text { May } \\
\text { June } \\
\text { July } \\
\text { August } \\
\text { September } \\
\text { October }\end{array}$ & $\begin{array}{r}4,760 \\
58,883 \\
37,309 \\
10,825 \\
3,292 \\
2,048 \\
1,940\end{array}$ & $\begin{array}{r}5,000 \\
49,449 \\
37,309 \\
10,825 \\
6,150 \\
2,976 \\
2,091\end{array}$ & $\begin{array}{l}50,472 \\
59,906 \\
59,906 \\
59,906 \\
57,048 \\
56,120 \\
55,969\end{array}$ & $\begin{array}{r}-240 \\
9,434 \\
0 \\
0 \\
-2,858 \\
-928 \\
-151\end{array}$ \\
\hline \multicolumn{5}{|c|}{1987} \\
\hline $\begin{array}{l}\text { April } \\
\text { May } \\
\text { June } \\
\text { July } \\
\text { August } \\
\text { September } \\
\text { October }\end{array}$ & $\begin{array}{r}12,340 \\
17,886 \\
5,625 \\
3,018 \\
1,311 \\
976 \\
494\end{array}$ & $\begin{array}{r}7,857 \\
12,301 \\
5,625 \\
6,150 \\
6,027 \\
1,845 \\
4,920\end{array}$ & $\begin{array}{l}53,737 \\
59,322 \\
59,322 \\
56,190 \\
51,474 \\
50,605 \\
46,179\end{array}$ & $\begin{array}{r}4,483 \\
5,585 \\
0 \\
-3,132 \\
-4,716 \\
-869 \\
-4,426\end{array}$ \\
\hline
\end{tabular}




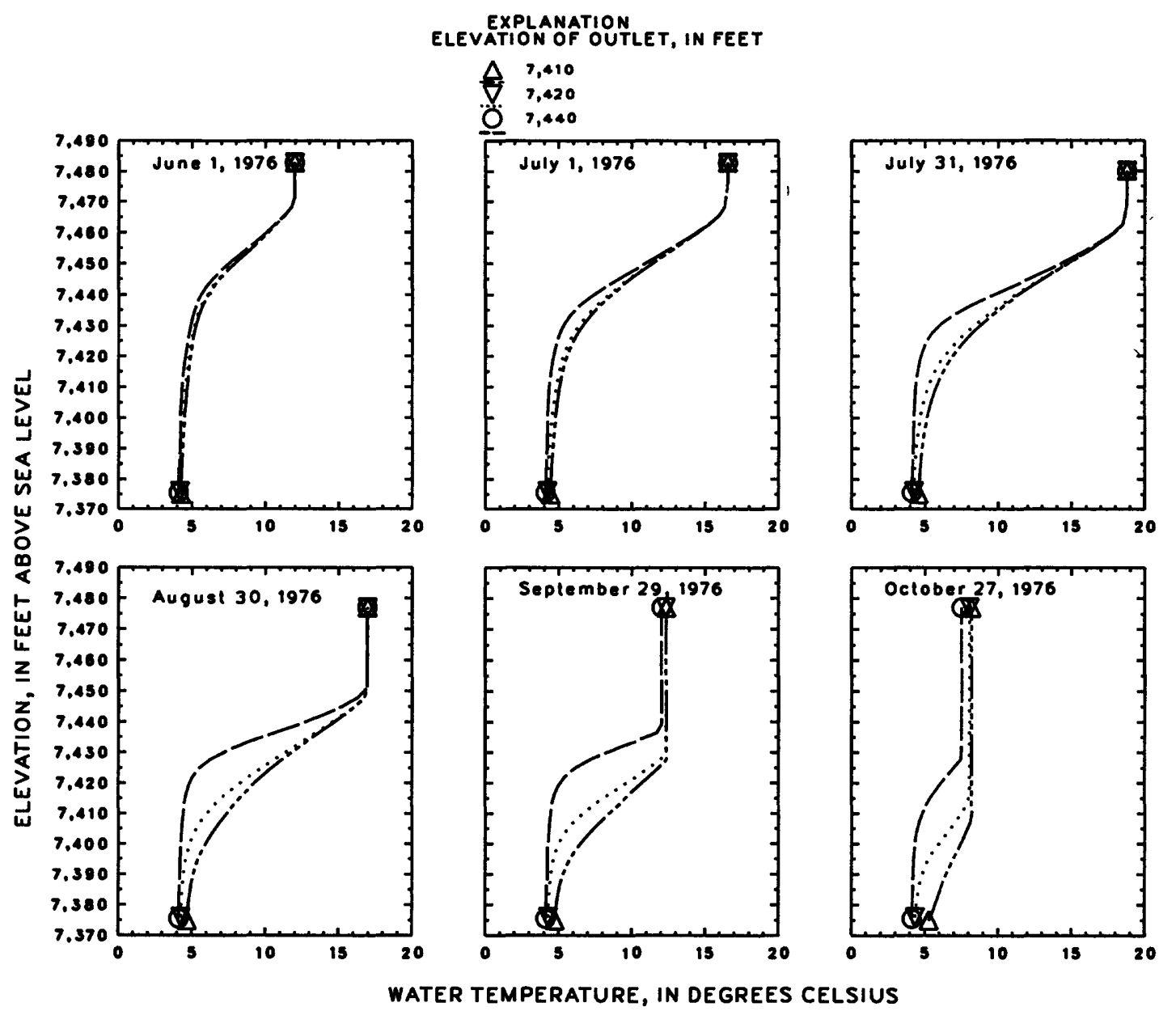

Figure 14.--Simulated temperature profiles for Wolford Mountain Reservoir, 1976. 


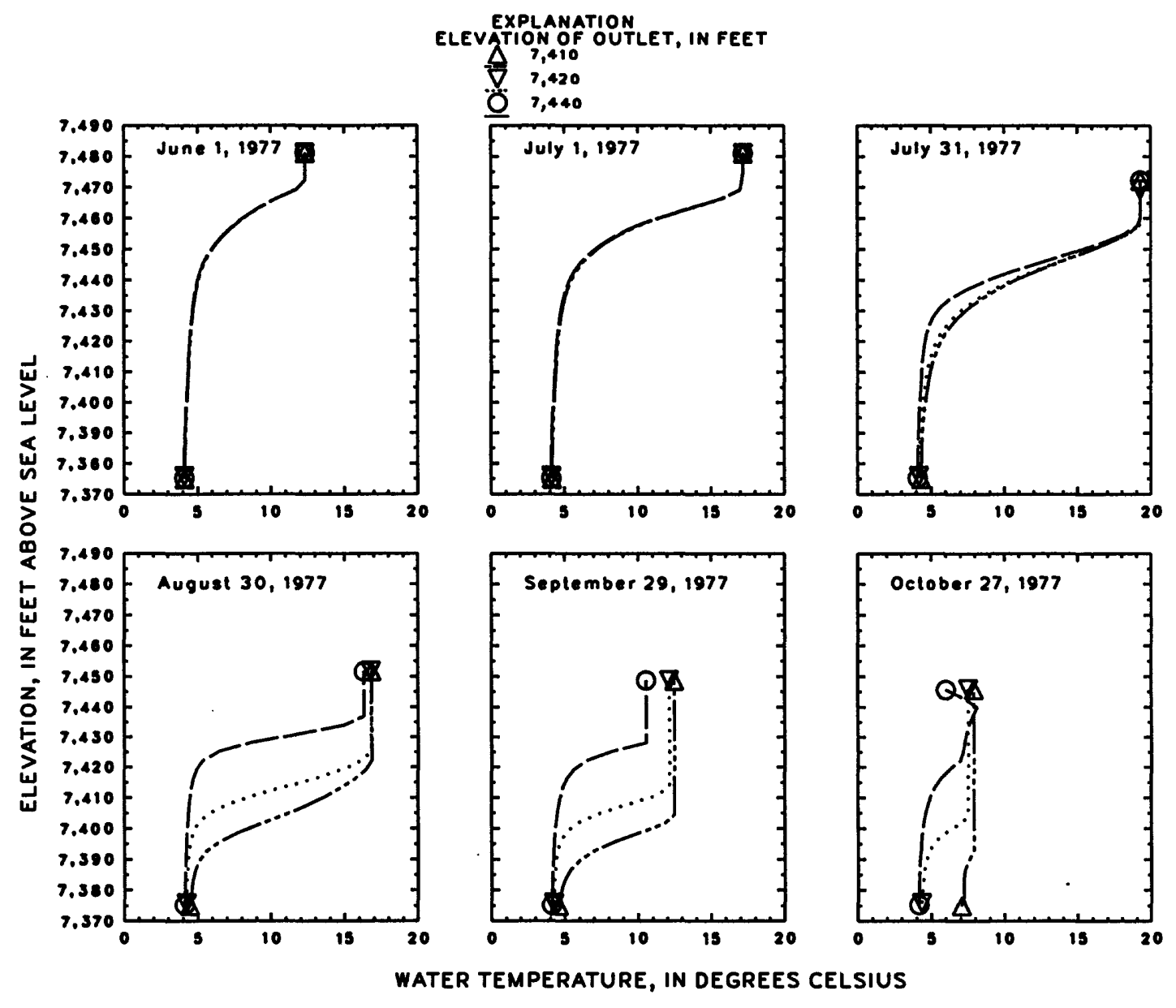

Figure 15.--Simulated temperature profiles for Wolford Mountain Reservoir, 1977. 


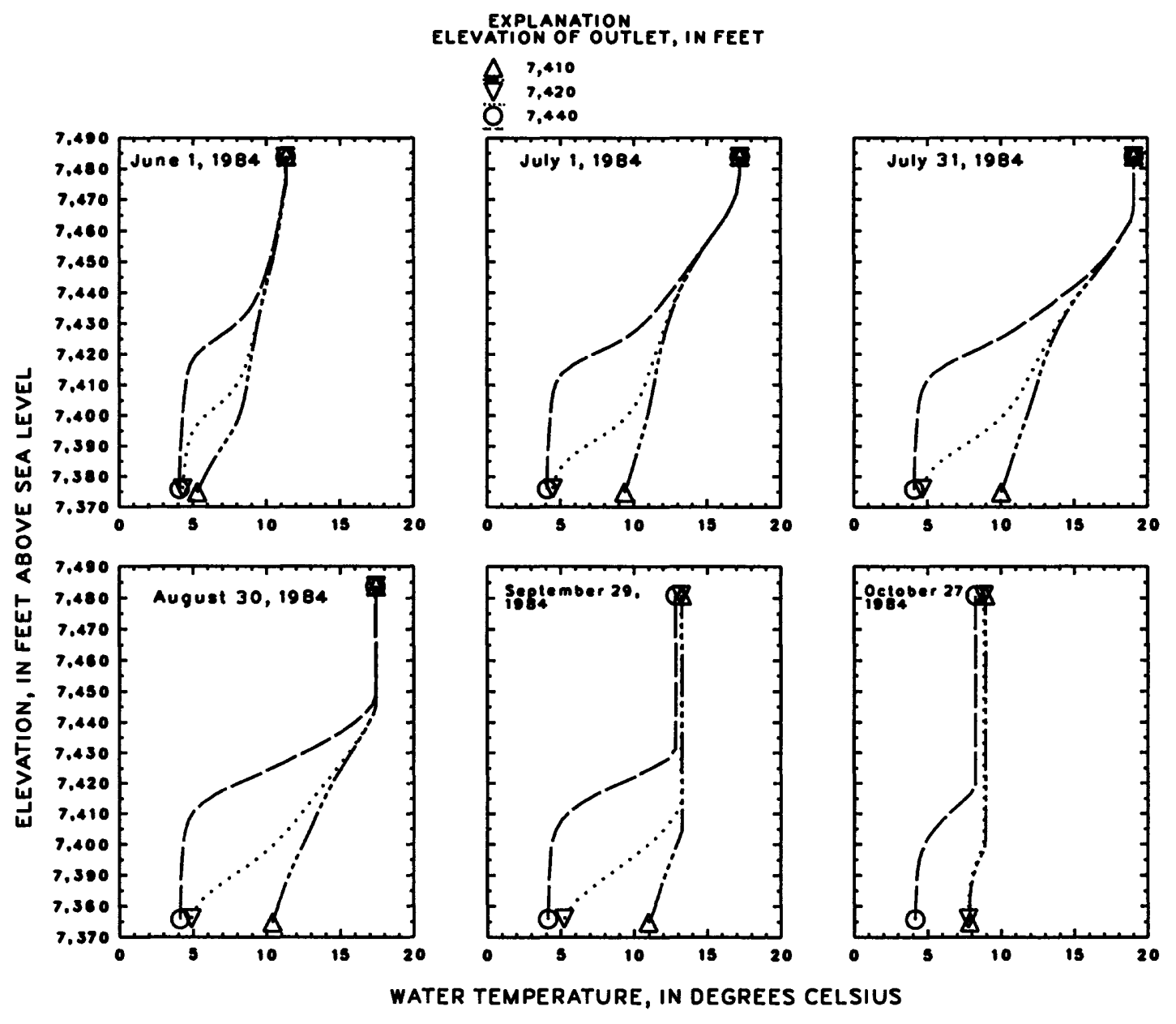

Figure 16.--Simulated temperature profiles for Wolford Mountain Reservoir, 1984. 


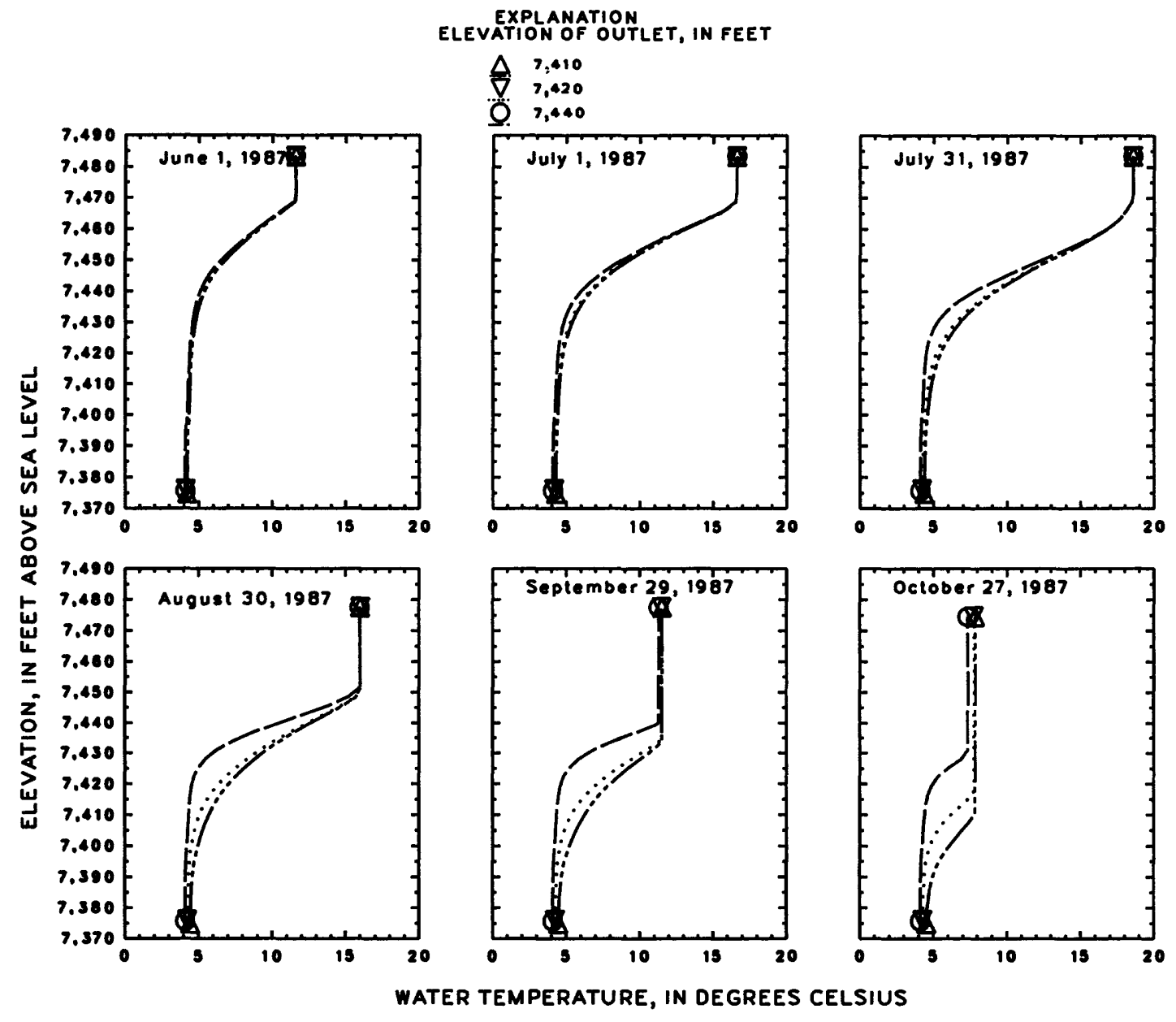

Figure 17.--Simulated temperature profiles for Wolford Mountain Reservoir, 1987. 
The temperature profiles indicated that the model is sensitive to elevation of the outlet. Thermal stratification was less well developed when the $7,410-\mathrm{ft}$ outlet was simulated, which was expected because the deeper outlet would induce deeper mixing. More distinct thermal stratification was simulated with the outlet at 7,440 ft, which caused formation of a thicker hypolimnion. Thermal stratification also was dependent upon reservoir operations and runoff volume. For example, with the outlet at 7,410 ft, thermal stratification did not develop in a year of greater than normal runoff (1984), but thermal stratification did develop in the other years simulated with the outlet at 7,410 ft. The large inflow discharge during May and June 1984 caused earlier and deeper mixing compared to other years. Greater heat transfer to deep layers was evident by the bottom temperature of $9.5{ }^{\circ} \mathrm{C}$ by July 1, 1984, with the outlet at 7,410 ft. The effect of runoff volume also is shown in profiles for the 7,440-ft outlet for 1984 and 1987 . Thermal stratification formed for both years with the outlet located at 7,440 ft; however, the hypolimnion in midsummer was about $15 \mathrm{ft}$ thicker in 1987 than it was in 1984 .

If the simulated inflow for 1976 is representative of hydrologic conditions of a normal runoff year for Muddy Creek, then for most years the temperature profile expected in Wolford Mountain Reservoir would be similar to the profiles shown in figure 14 . Thermal stratification was slightly more developed with the outlet at 7,440 ft than at 7,410 or 7,420 ft. The thermocline was higher and the temperature gradient in the metalimnion was greater by late summer with increasing outlet elevation. Simulated temperatures in layers near the bottom were about 4 to $5{ }^{\circ} \mathrm{C}$ from May through October for all outlet elevations. On the basis of calibration results, the simulated temperatures in the deepest layers may be too cold during summer. Overturn in autumn occurred earlier with deeper outlets (compare October 27, 1976, profiles).

The temperature profiles during years of less than normal runoff may depend on reservoir operations, based on temperature simulations for 1977 and 1987. The temperature profiles are similar for 1977 (fig. 15) and 1987 (fig. 17) through July. The simulated reservoir operations for 1977 caused a rapid decrease in reservoir storage in July and August. The temperature gradients in the metalimnion are greater in 1977 than in 1987 in late summer, especially with the outlet at 7,410 or 7,420 ft (compare August 30 profiles for 1977 and 1987). However, the thickness and volume of the hypolimnion in 1977 was less than it was in 1987 because of the small reservoir storage in late summer of 1977 . Overturn in the reservoir during fall with the deep outlet $(7,410 \mathrm{ft}$ ) occurred slightly earlier in 1977 than it did in 1987.

The outflow temperatures shown in figures 18 and 19 indicated that higher outlet elevation resulted in warmer outflow temperatures. The outflow temperatures at the $7,420-\mathrm{ft}$ outlet usually were not more than $1{ }^{\circ} \mathrm{C}$ warmer than outflow temperatures at the 7,410-ft outlet; this difference probably is less than the model error for outflow temperatures. Outflow through the 7,440-ft outlet was as much as 3 to $4{ }^{\circ} \mathrm{C}$ warmer than outflow temperatures through the 7,420-ft outlet during midsummer. In a year of normal runoff (1976), temperature simulations indicate that the outflow from Wolford Mountain Reservoir would warm to about 9 to $10^{\circ} \mathrm{C}$ by early october at the 7,410 - and $7,420-\mathrm{ft}$ outlets and to $12{ }^{\circ} \mathrm{C}$ by mid-September at the $7,440-\mathrm{ft}$ outlet. The reservoir 

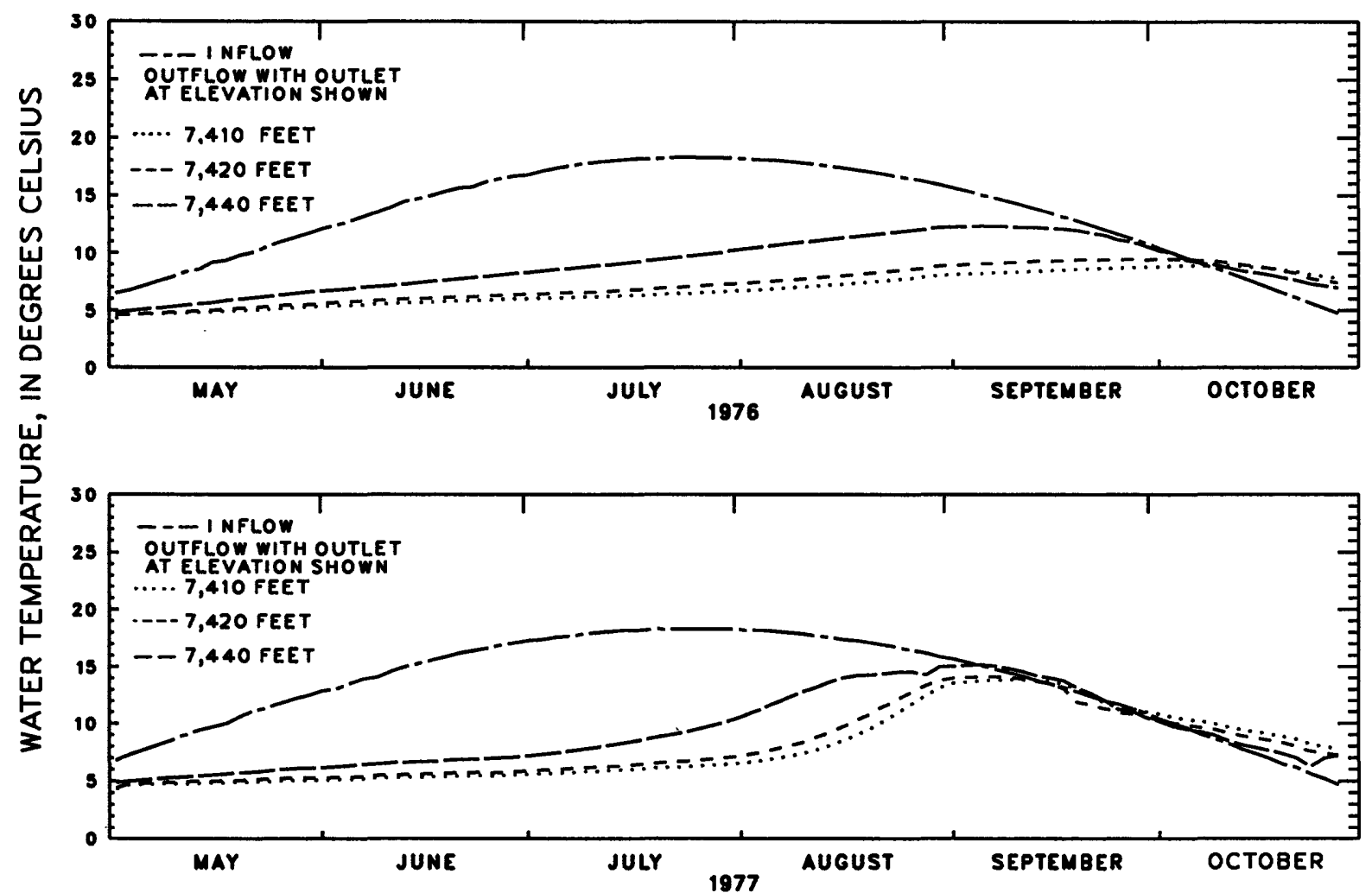

Figure 18.--Simulated inflow and outflow temperatures for Wolford Mountain Reservoir, 1976 and 1977. 

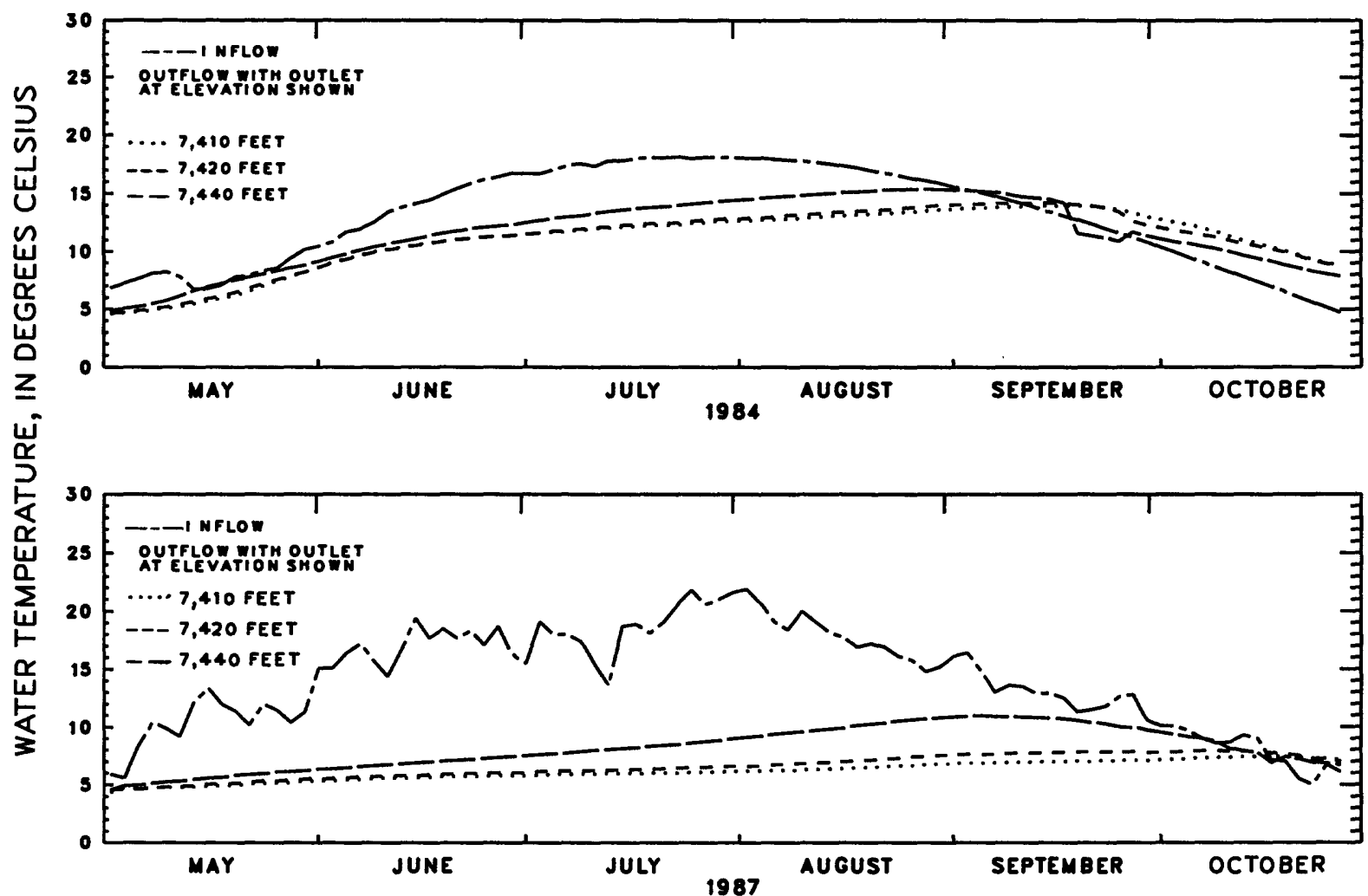

Figure 19.--Simulated inflow and outflow temperatures for 1984 and measured inflow and simulated outflow for 1987 for Wolford Mountain Reservoir. 
release water would be cooler than the incoming water in Muddy Creek during most of the summer. The warmest simulated outflow temperatures (about $14{ }^{\circ} \mathrm{C}$ ) at the 7,410- and 7,420-ft outlets occurred during 1977 (less than normal runoff) and 1984 (greater than normal runoff). Outflow temperatures increase in August 1977 because of the large drawdown of the reservoir, which brings warmer water into the withdrawal layers. Warmer outflow temperatures occurred in 1984 because more heat was transferred into deeper layers during the unusually large inflow and outflow discharges during May and June. Outflow temperatures during years of less than normal runoff may be colder than outflow temperatures during normal or greater than normal runoff years if reservoir drawdown was not as large as 1977. Outflow temperatures during summer of 1987 (fig. 19) were 1 to $2{ }^{\circ} \mathrm{C}$ colder than outflow temperatures in 1976 and as much as $5{ }^{\circ} \mathrm{C}$ colder than outflow temperatures in 1977 and 1984. For all 4 years simulated, the inflow stream temperature and outflow water temperature would be about the same by late September or early October.

Potential errors in the temperature simulations caused by using climatological data that were not measured at the reservoir site were discussed for Rock Creek Reservoir and can be applied to Wolford Mountain Reservoir. Because the outlets were not at the reservoir bottom, the temperature model likely would give reasonable approximations of expected outflow temperatures from Wolford Mountain Reservoir. That conclusion assumes that large errors did not occur in the simulated temperature profiles in the withdrawal layers.

\section{WATER QUALITY}

Water quality of lakes and reservoirs can be evaluated using various models. Some are detailed, process-orientated models (such as Brown and others, 1985) that attempt to describe the various chemical and biological processes that occur within lakes and reservoirs using mathematical equations in a computer program. Because of difficulties in applying such models to proposed reservoirs, some water-quality variables were evaluated by use of simpler empirical models. An empirical model usually defines one variable in terms of one or more other variables, using a statistical relation developed from measured data.

Dissolved-solids concentration was studied in terms of modeling specific conductance as a conservative constituent using the water-quality routine in the thermal model. Phosphorus and nitrogen concentrations were studied using empirical models. Algal growth was estimated using empirical models that predict chlorophyll-a concentrations and also by analyzing samples collected for algal-growth potential from the inflow streams at the reservoir sites.

\section{Specific Conductance and Dissolved Solids}

Dissolved-solids concentration is an important indicator of inorganic water quality and can be an important variable for determining suitability of water for various uses. Because dissolved-solids concentration and specific 
conductance are measures of the quantity of inorganic constituents in solution, specific conductance is directly related to the dissolved-solids concentrations for the range of specific conductance measured in Rock and Muddy Creeks. Knowledge of specific-conductance profiles in a reservoir and in the outflow yields information about the distribution of dissolved-solids concentrations and inorganic constituent concentrations in the reservoir. Specificconductance data often are collected at greater frequency than dissolvedsolids data and would provide more detailed data for modeling purposes.

The temperature model used in this study has a routine that predicts the concentration distribution of a single water-quality variable (Adams, 1974). The concentration distribution is the result of the same internal-flow pattern in a reservoir that controls the temperature distribution. Concentration of the constituent is determined by the one-dimensional, mass-transport equation that incorporates appropriate source and decay terms. Specific conductance was modeled as a conservative constituent by assuming no chemical reactions occurred that would alter concentrations of dissolved major ions and subsequently change specific conductance. Therefore, the estimated specific conductance would be dependent only on the mass-transport equation that has no source and sink terms.

The model was tested with specific-conductance data collected at Williams Fork and Green Mountain Reservoirs during 1986 and 1987. Daily specificconductance data were recorded by water-quality monitors located at the inflow and outflow sites previously described for both reservoirs (fig. 1).

Specific-conductance profiles were measured in the reservoirs in conjunction with the temperature measurements. The model was not actually calibrated for specific conductance; the only calibration done was for the temperature model, which defines the internal flow pattern in the reservoirs. Once the temperature model was calibrated, specific-conductance data were input into the model, and the simulated profiles and outflow for specific conductance were compared to the measured data.

Comparisons of measured specific conductance to simulated specific conductance for 1987 at Williams Fork and Green Mountain Reservoirs are shown in figure 20. Two profiles were measured at each reservoir in 1986, but the profiles are not shown because problems occurred with some of the specificconductance measurements. The specific conductance in the outflow for 1986 and 1987 at both reservoirs are compared to simulated outflow specific conductance in figures 21 and 22 .

The model underestimated the specific conductance in the upper part of Williams Fork Reservoir for 1987. Part of this error may be caused by underestimation of the inflow specific conductance by use of data measured at gaging station 09037500 . There are irrigation return flows into the reservoir that were not taken into account that may have substantially larger specific conductance than the Williams Fork. The simulated specific conductance in the outflow from Williams Fork Reservoir agreed closely with measured data at gaging station 09038500 for both years. Errors in specific conductance in the outflow generally were less than $10 \mu \mathrm{S} / \mathrm{cm}$. 
EXPLANATION

I MEASURED

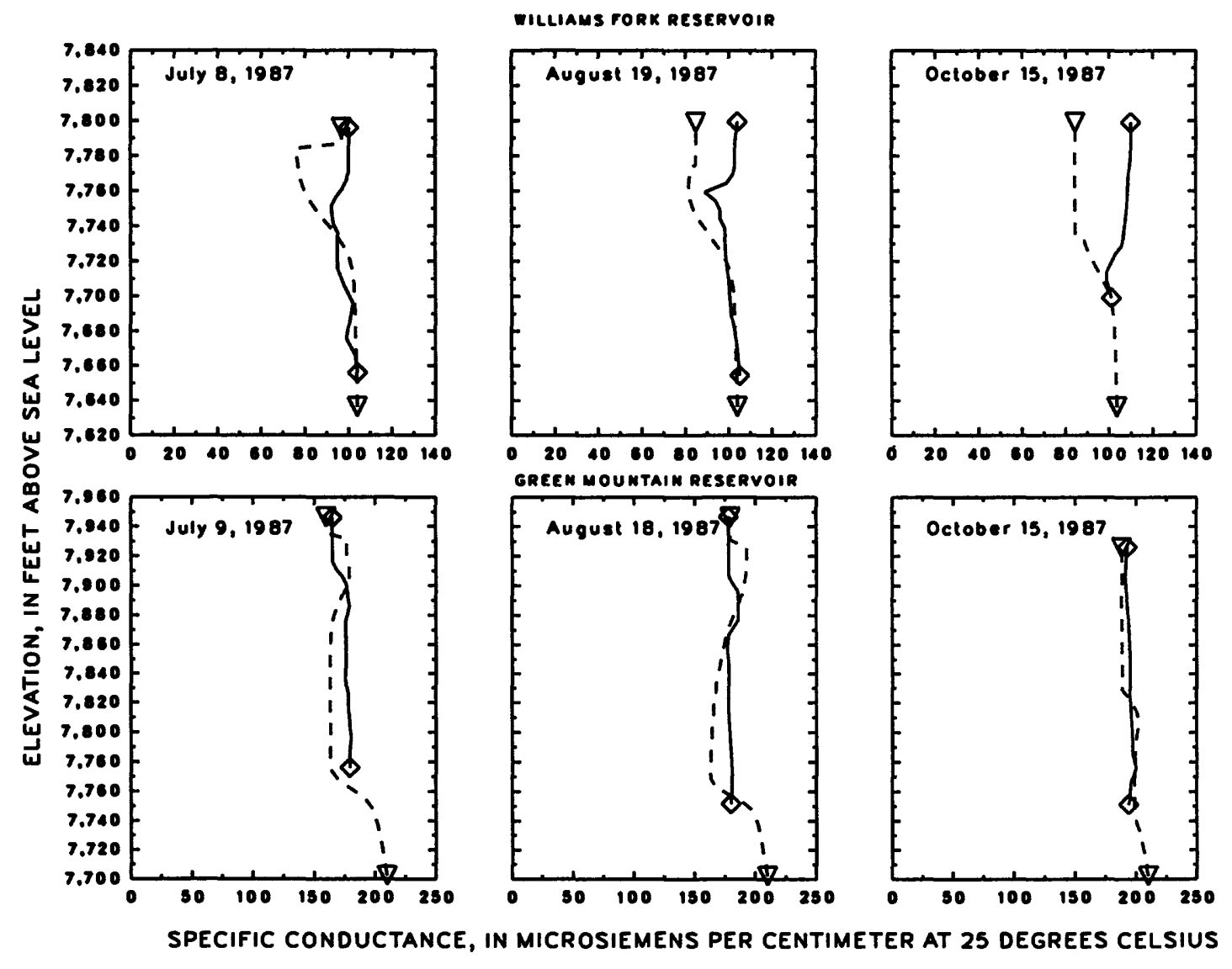

Figure 20.--Measured and simulated specific-conductance profiles for Williams Fork and Green Mountain Reservoirs, 1987. 

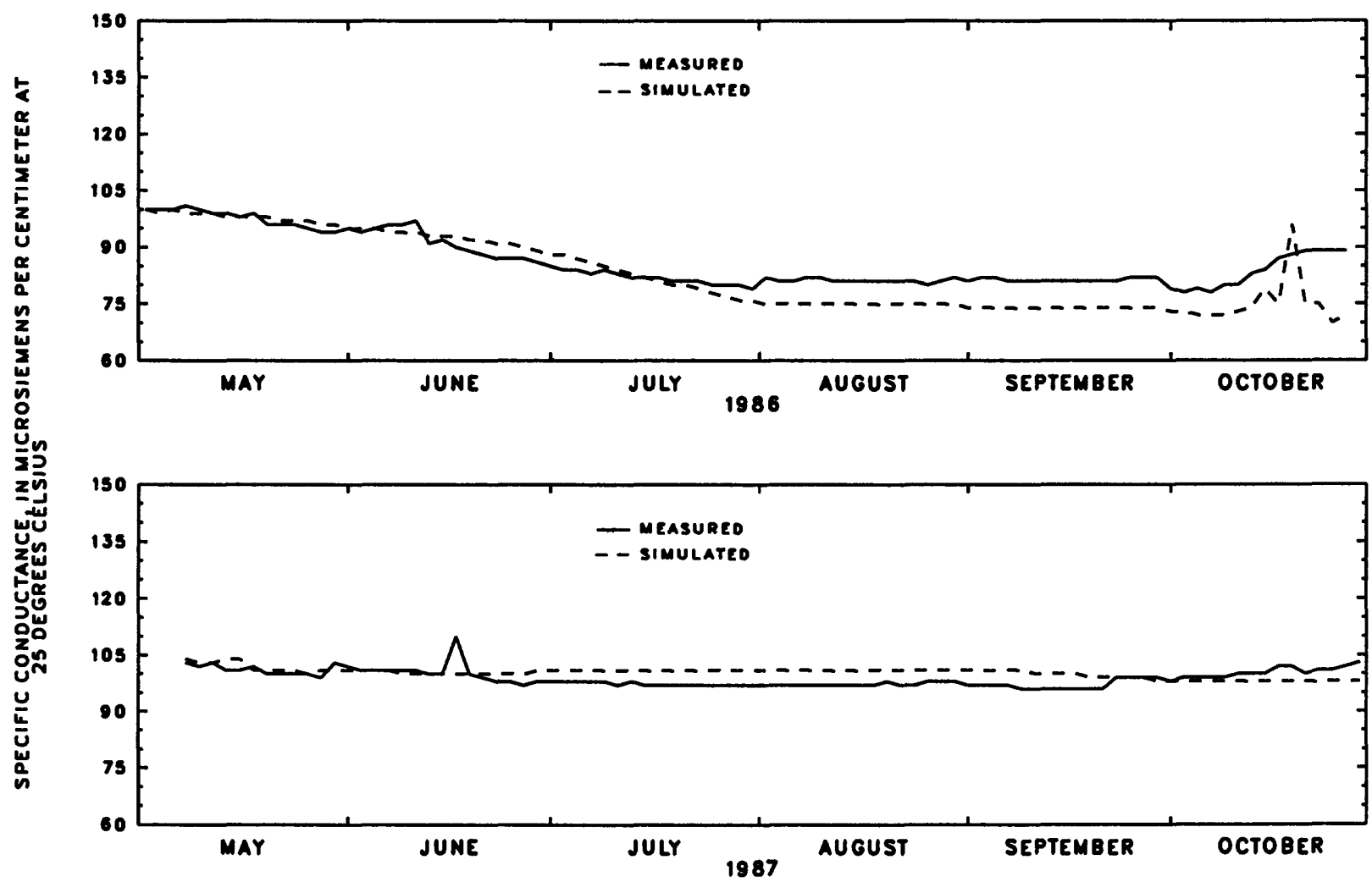

Figure 21.--Measured and simulated specific conductance of outflow from Williams Fork Reservoir, 1986-87. 

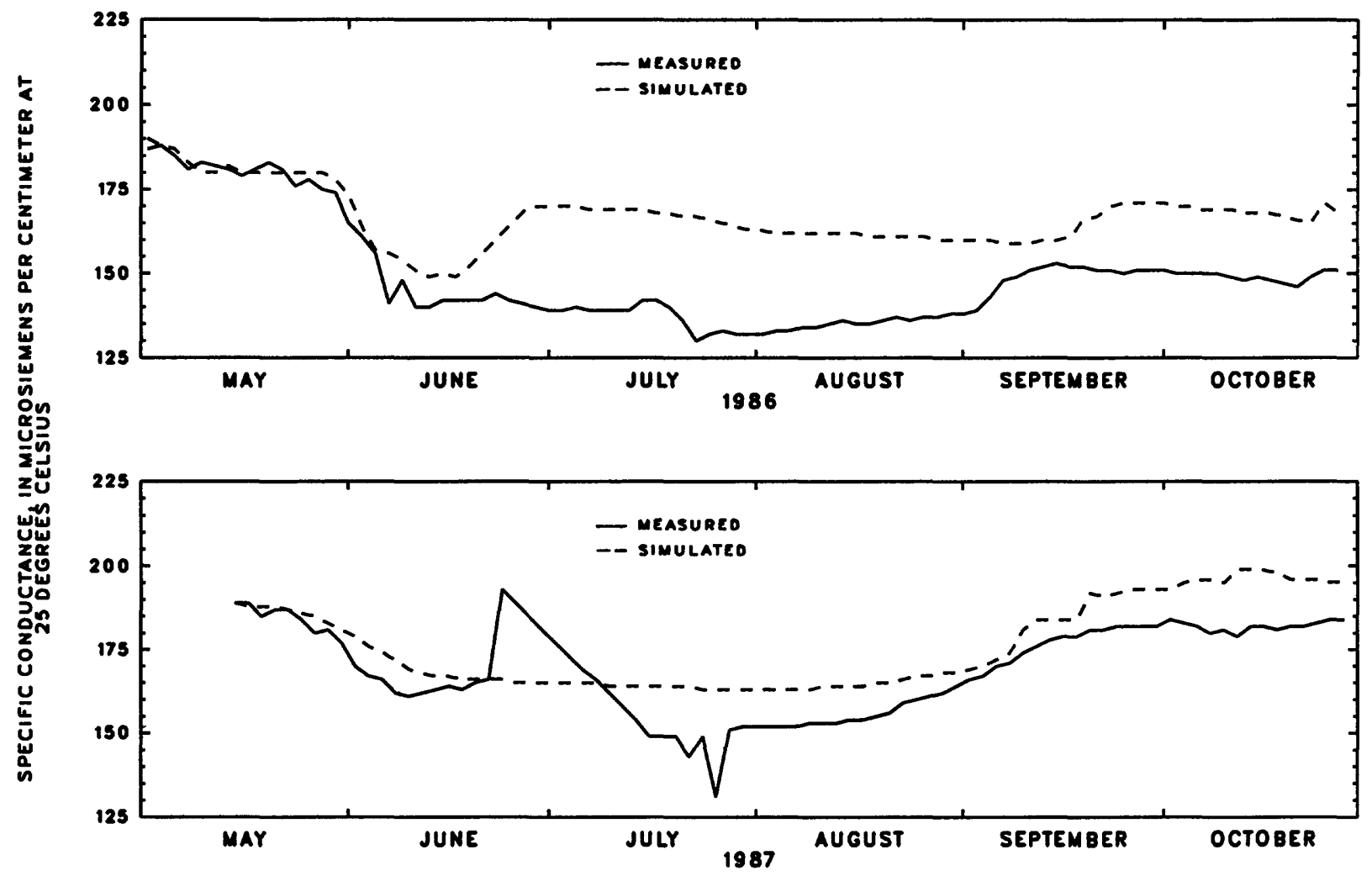

Figure 22.--Measured and simulated specific conductance of outflow from Green Mountain Reservoir, 1986-87. 
The simulated specific conductance for Green Mountain Reservoir for 1987 usually was within 15 percent of the measured specific conductance. It is not known if the model results shown for the lower $50 \mathrm{ft}$ are correct because these layers could not be measured using the equipment available. Simulated specific conductance in the outflow generally was overestimated. Maximum error was about $25 \mu \mathrm{S} / \mathrm{cm}$. Partial explanation for the overestimation by the model may be that specific conductance measured at gaging station 09053500 was assumed to be representative of specific conductance of all inflow into Green Mountain Reservoir. That assumption may cause overestimation of inflow specific conductance, because specific conductance of tributary streams that discharge into the west side of the reservoir was smaller than specific conductance of the Blue River. The model simulated specific conductance in the outflow more accurately for 1987 than it did for 1986. The model did not simulate the two large changes of specific conductance that occurred in June and July 1987. Those fluctuations may have been caused by rapid changes in the outflow discharge.

Specific conductance for the proposed Rock Creek and Wolford Mountain Reservoirs was simulated by inputing daily specific-conductance values for each simulation period into the temperature model. Daily specific conductance was recorded in 1986 and 1987 at the Crater and Muddy Creek gages. Regression relations of specific conductance to stream discharge and time of year were computed for each site. These relations were used to estimate the daily specific conductance for May through October for each simulation period. On the basis of 21 measurements of specific conductance at the Toponas gage, the specific conductance of Rock Creek at the Crater gage was adjusted to the Rock Creek Reservoir site to account for an apparent downstream increase of specific conductance from the Toponas gage to the Crater gage. A regression relation was used to compute specific conductance at the Toponas gage from specific conductance at the Crater gage. Recorded data from the Muddy Creek gage were used as the inflow specific conductance for Wolford Mountain Reservoir for 1987.

Specific conductance for Rock Creek Reservoir was simulated using stream discharge for a greater than normal runoff year (1957), a normal runoff year (1972), and a less than normal runoff year (1977). Simulated specificconductance profiles are shown in figure 23. Specific conductance for 1962 also was simulated, but the profiles for 1962 are similar to the profiles for 1957 and are not shown. Simulated specific conductance in the inflow is compared to simulated specific conductance in the outflow in figures 24 and 25. Specific conductance was simulated for Wolford Mountain Reservoir using stream discharge for a normal runoff year (1976), a greater than normal runoff year (1984), and a less than normal runoff year (1987). Specific-conductance profiles simulated for 1977 are similar to the results for 1987 and are not shown. Specific-conductance profiles are shown in figures 26 through 28 and simulated specific conductance in the inflow is compared to simulated specific conductance in the outflow in figures 29 and 30 .

The magnitude of simulated specific-conductance profiles is dependent on the initial specific-conductance profile of the reservoir at the beginning of the simulation period (May 1). The initial specific-conductance profile for a 

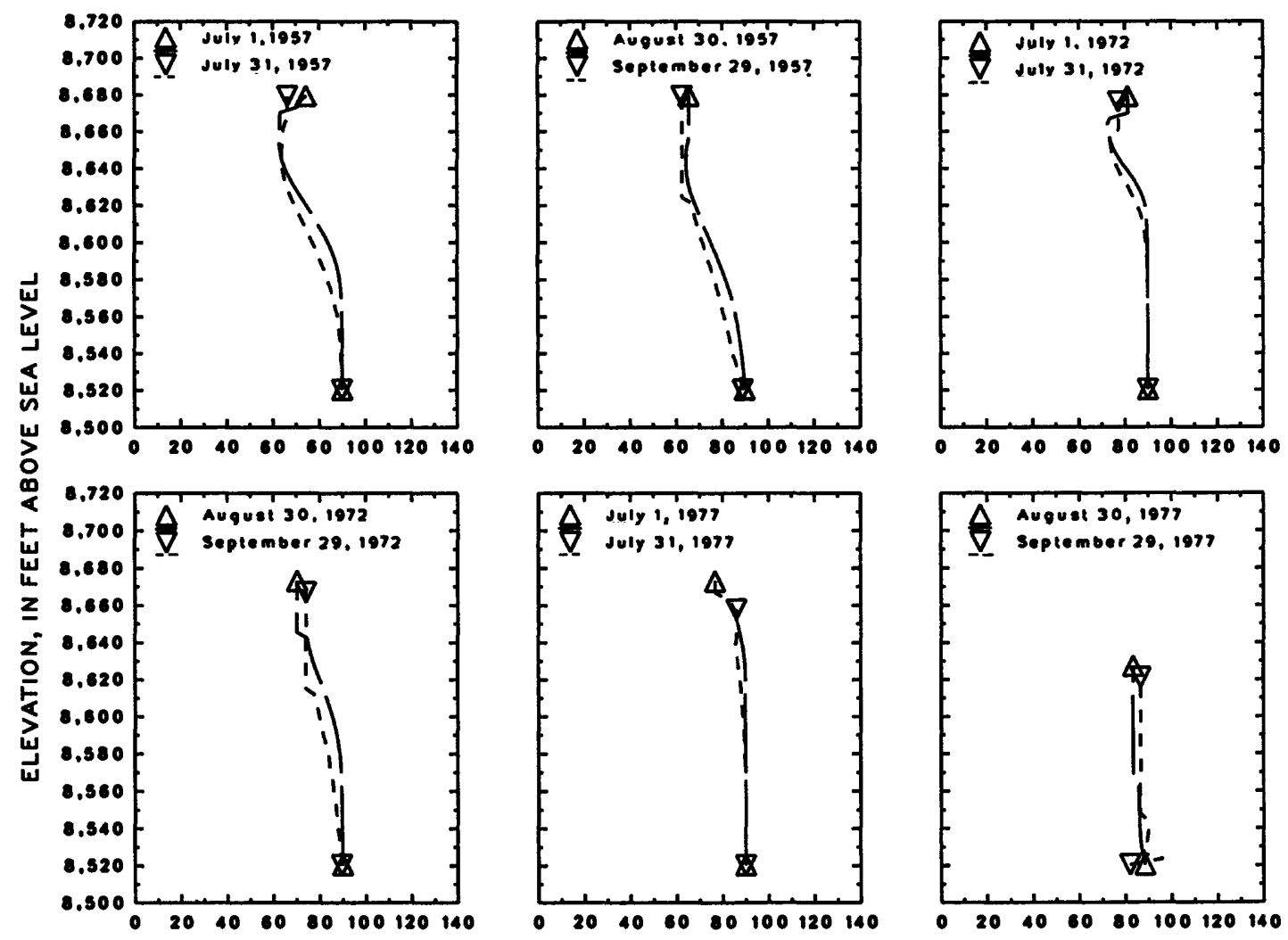

SPECIFIC CONDUCTANCE, IN MICROSIEMENS PER CENTIMETER AT 25 DEGREES CELSIUS

Figure 23.--Simulated specific-conductance profiles for Rock Creek Reservoir, 1957, 1972, and 1977. 

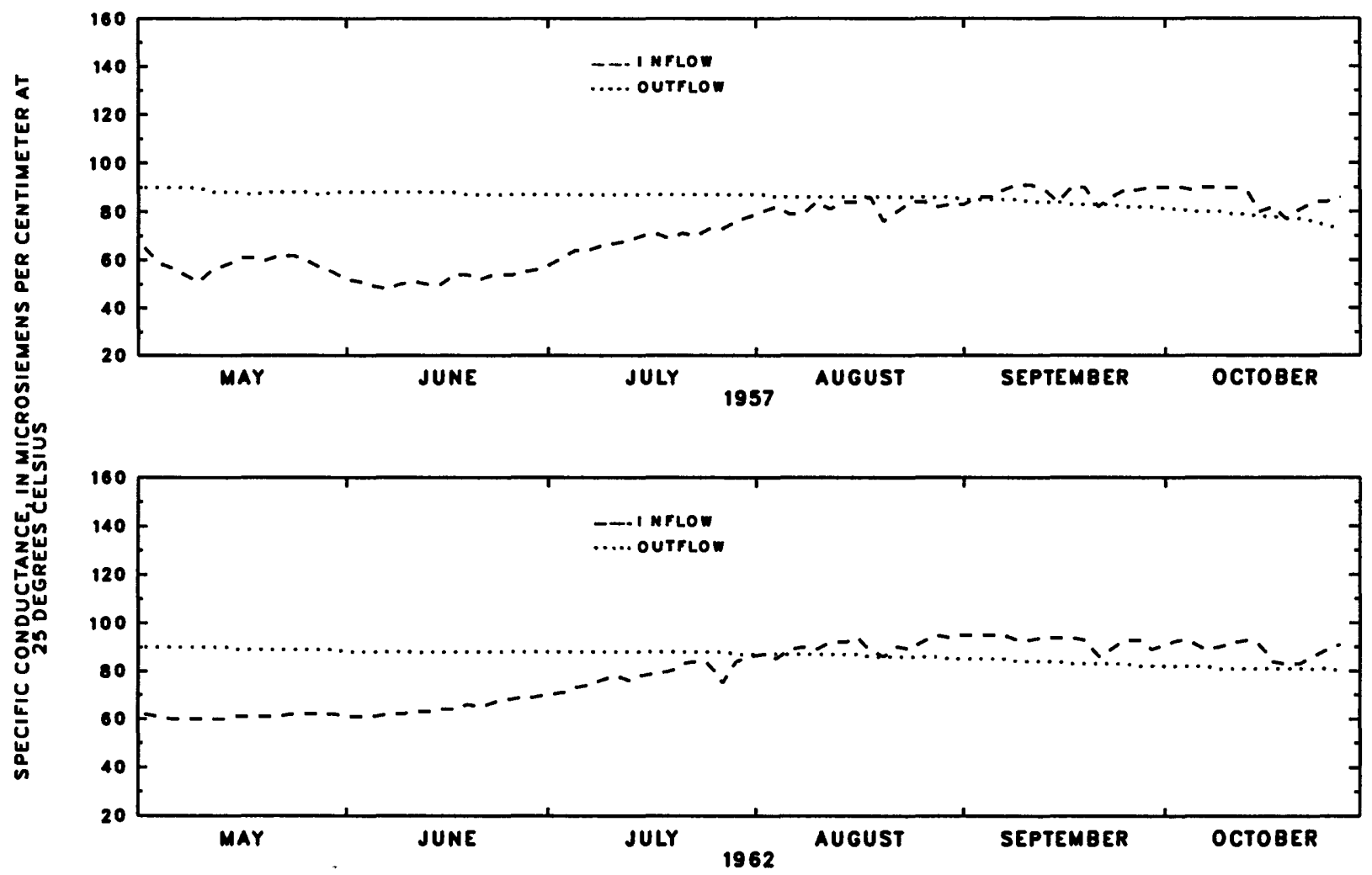

Figure 24.--Simulated inflow and outflow specific conductance for Rock Creek Reservoir, 1957 and 1962. 

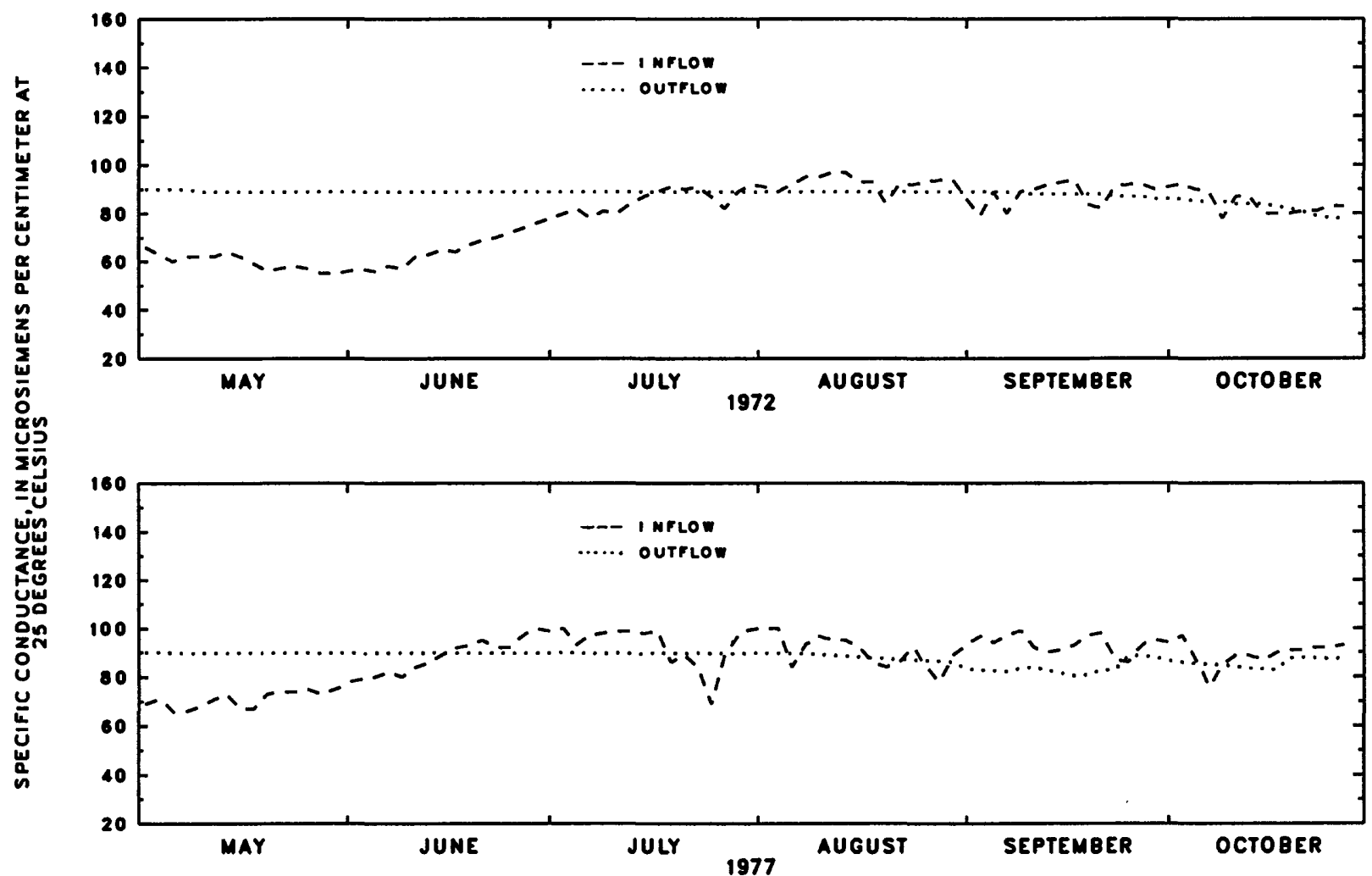

Figure 25.--Simulated inflow and outflow specific conductance for Rock Creek Reservoir, 1972 and 1977. 

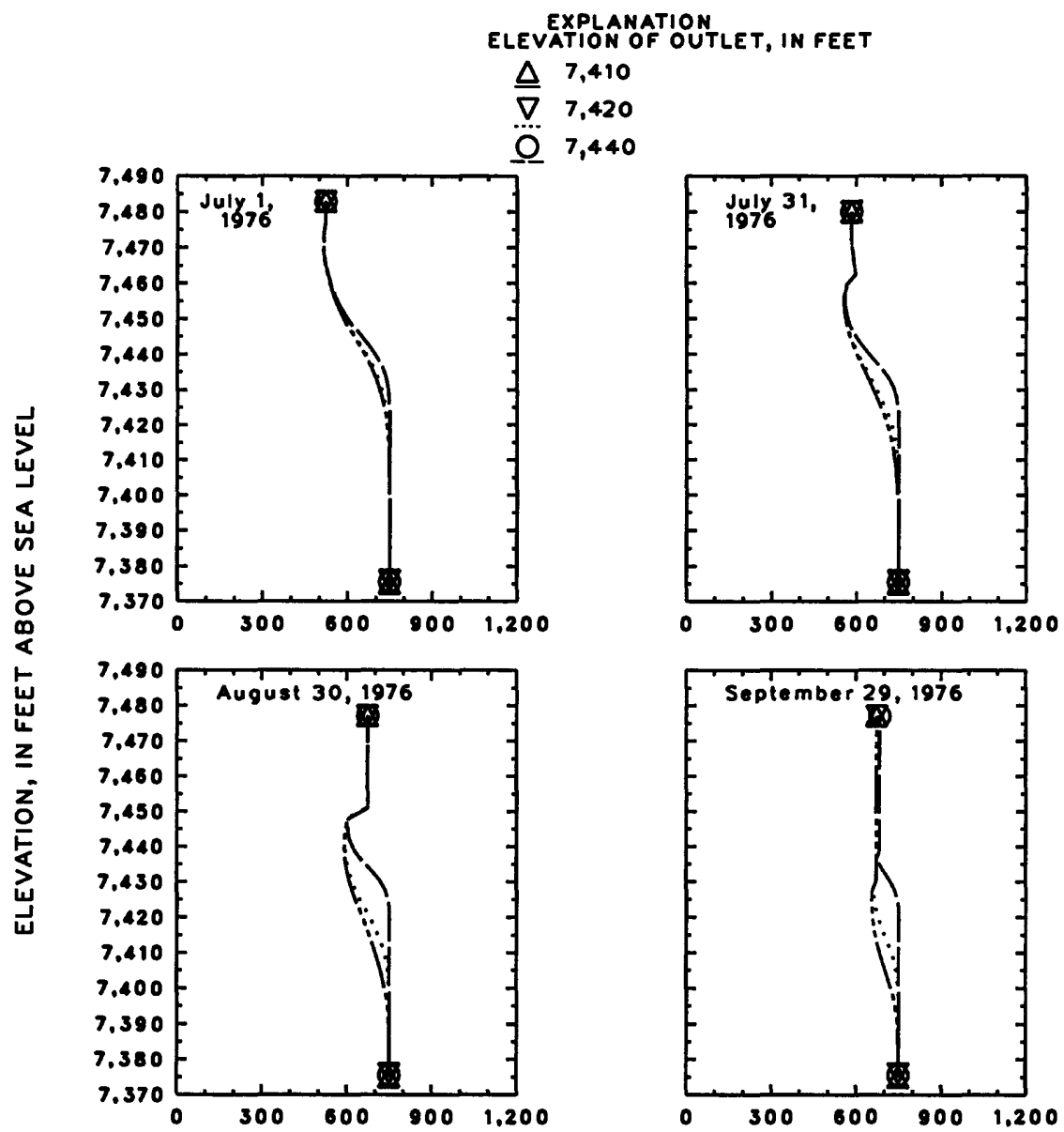

SPECIFIC CONDUCTANCE, IN MICROSIEMENS PER CENTIMETER AT 25 DEGREES CELSIUS

Figure 26.--Simulated specific-conductance profiles for Wolford Mountain Reservoir, 1976. 


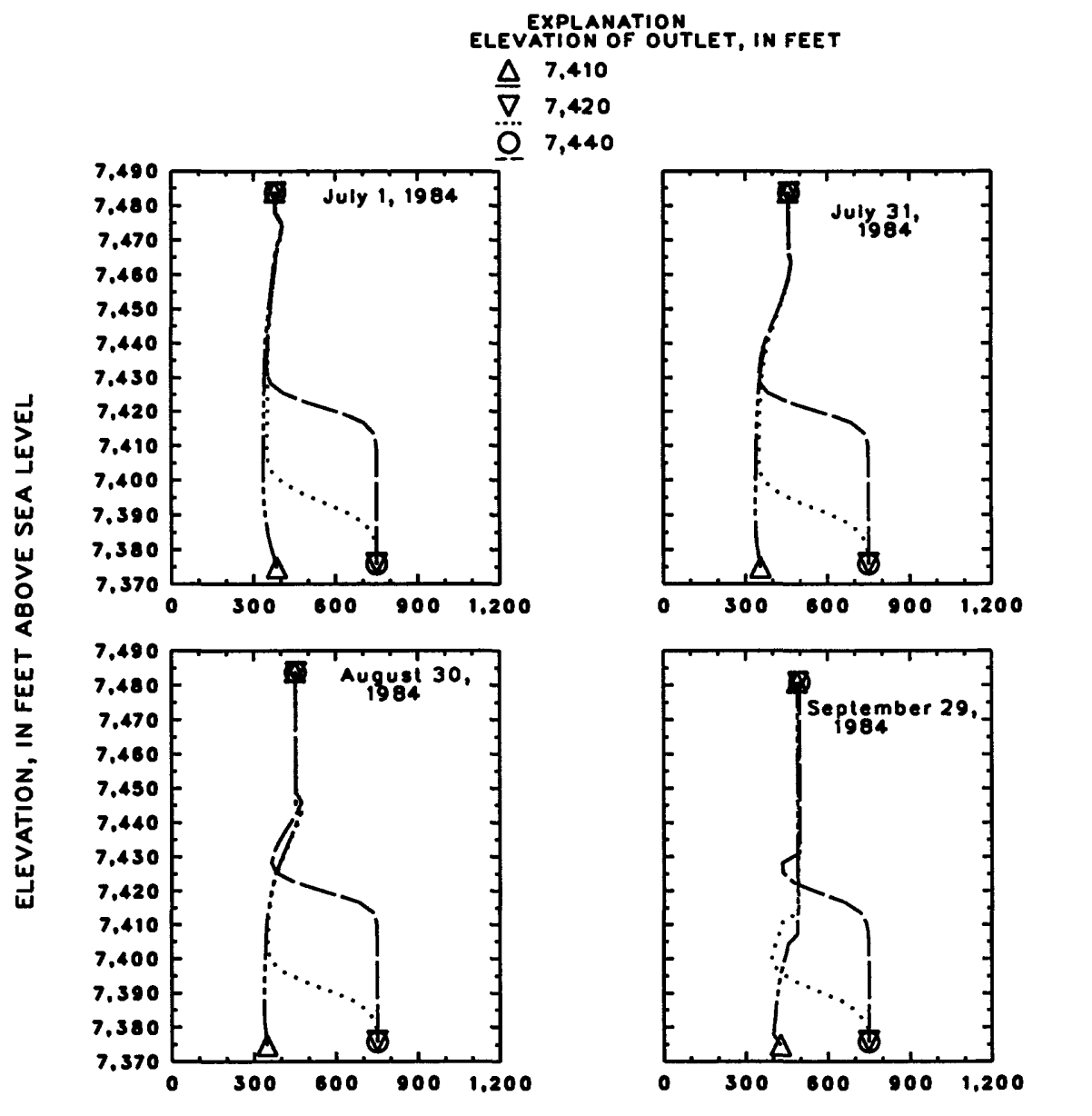

SPECIFIC CONDUCTANCE, IN MICROSIEMENS PER CENTIMETER AT 25 DEGREES CELSIUS

Figure 27.--Simulated specific-conductance profiles for Wolford Mountain Reservoir, 1984. 


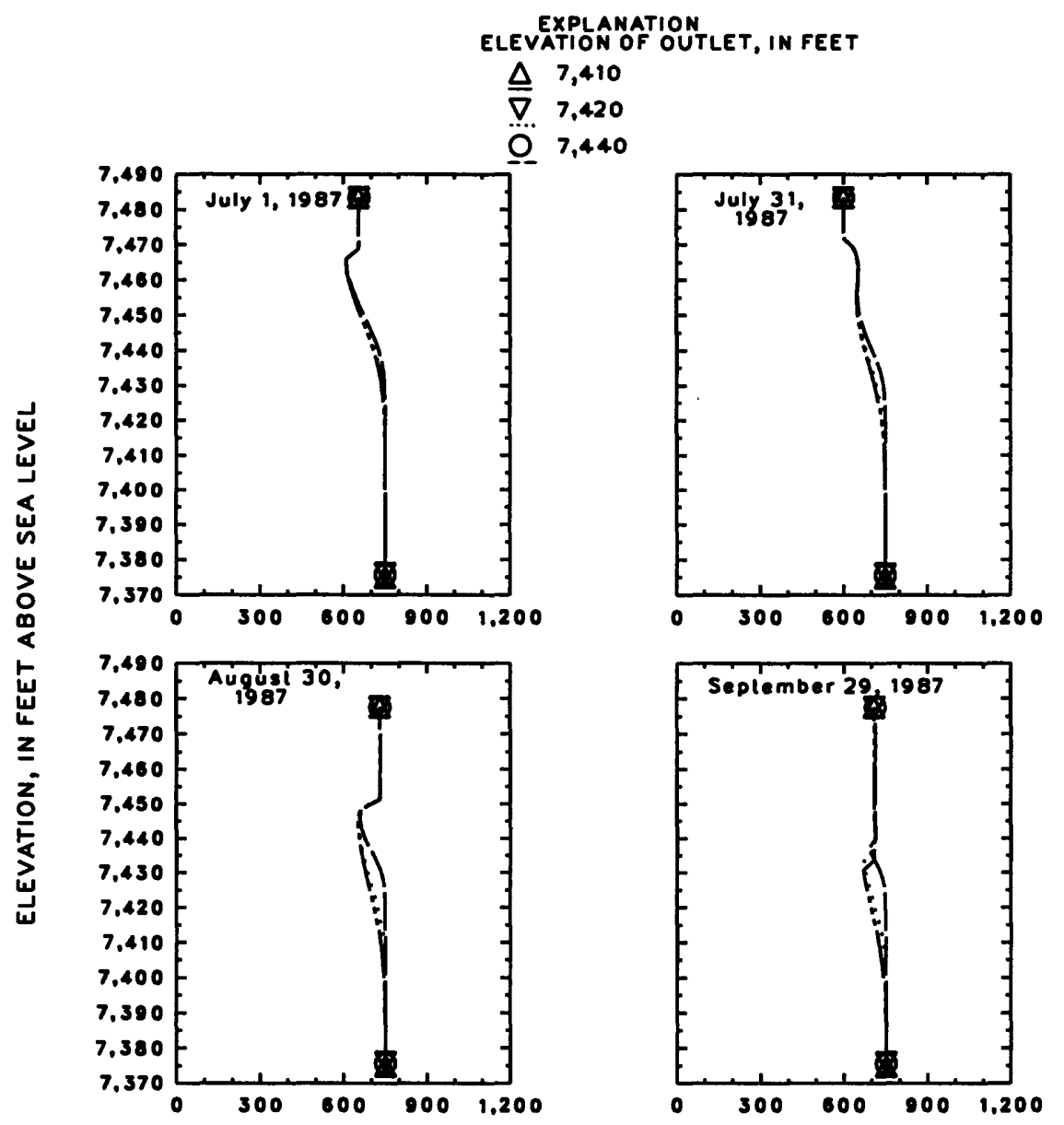

SPECIFIC CONDUCTANCE, IN MICROSIEMENS PER CENTIMETER AT 25 DEGREES CELSIUS

Figure 28.--Simulated specific-conductance profiles for Wolford Mountain Reservoir, 1987. 


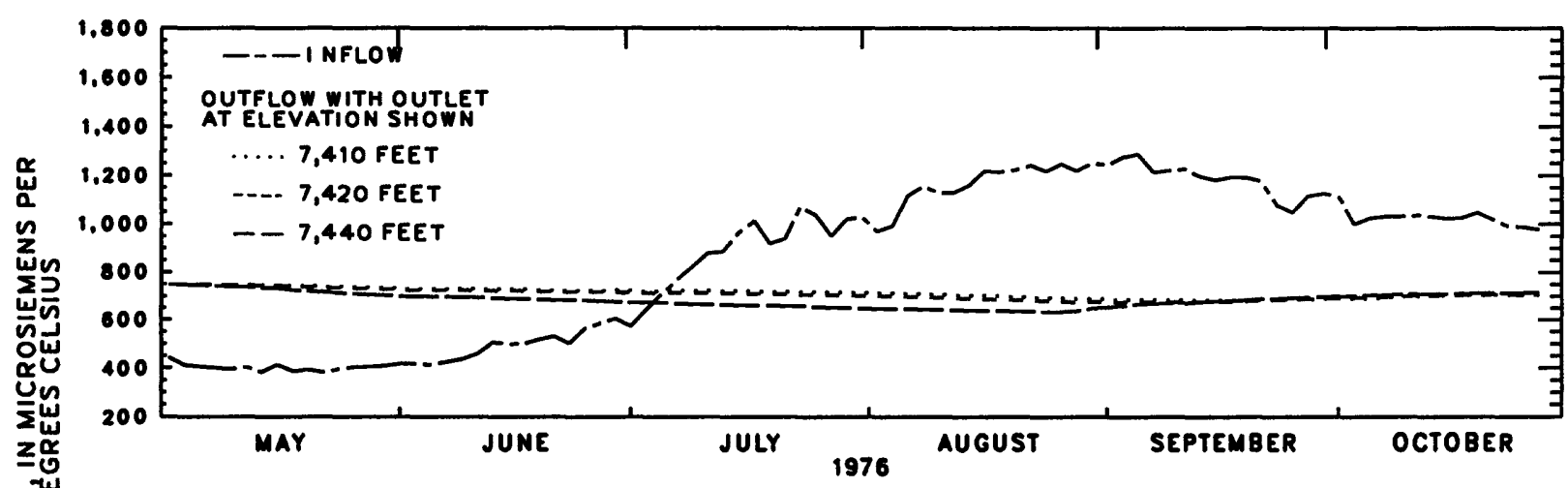

वَّ

迎

虾

实

敦

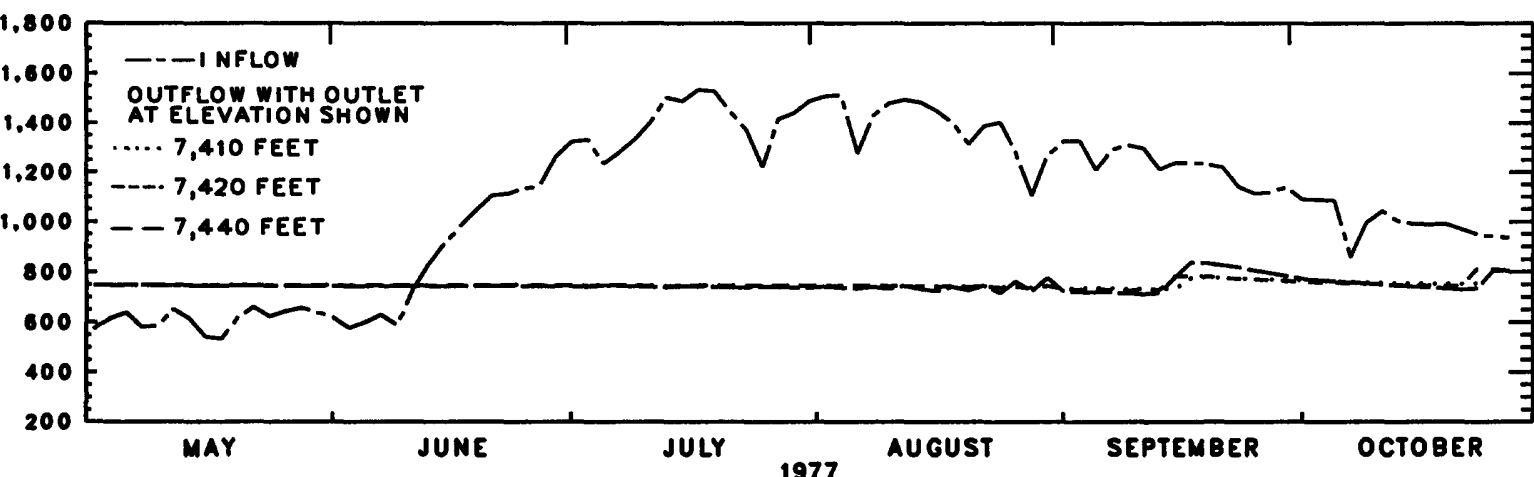

Figure 29.--Simulated inflow and outflow specific conductance for Wolford Mountain Reservoir, 1976 and 1977. 


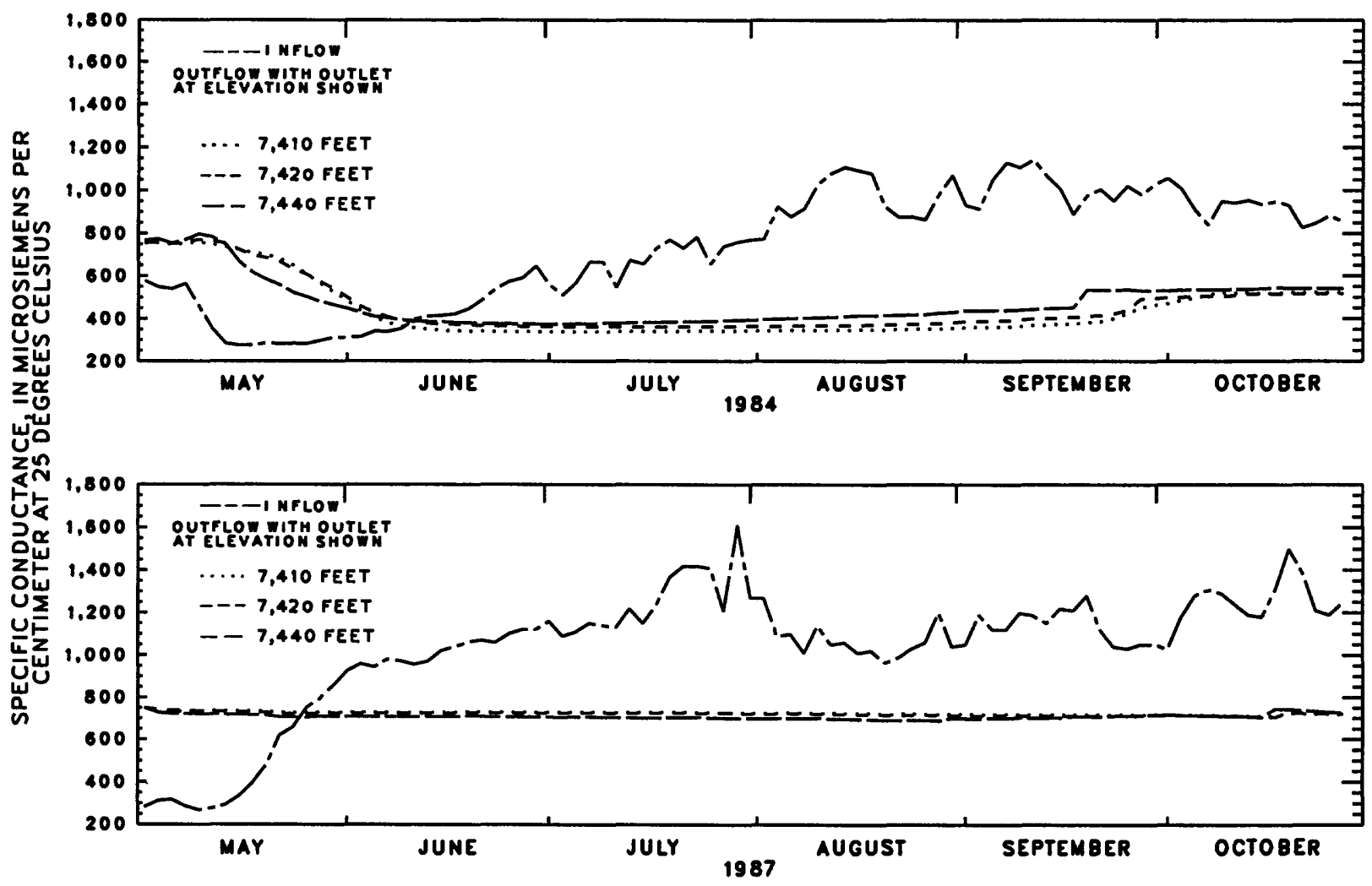

Figure 30.--Simulated inflow and outflow specific conductance for 1984 and measured inflow and simulated outflow specific conductance for 1987 for Wolford Mountain Reservoir. 
proposed reservoir cannot be known with certainty. By computing dischargeweighted means of daily specific conductance measured in Rock and Muddy Creeks and by considering possible effects on specific conductance from evaporation, ground-water inflow, and leaching, initial specific-conductance profiles for the proposed reservoirs were selected. The inflow water was assumed to be completely mixed in the reservoirs at the beginning of the simulation period; therefore, the specific-conductance profile in the reservoirs was assumed to have the same value in all layers. An initial specific-conductance profile of $90 \mu \mathrm{S} / \mathrm{cm}$ was used for Rock Creek Reservoir and $750 \mu \mathrm{S} / \mathrm{cm}$ was used for Wolford Mountain Reservoir. Antecedent conditions were not incorporated into estimates of initial specific-conductance profiles. The specific conductance in a reservoir on May 1 may be affected by previous reservoir operations and hydrologic events. The simulation results for the proposed reservoir sites. should be examined for general trends and for the effects of reservoir operations and variation of inflow discharge on specific conductance in the reservoirs and in the outflows. It is important to emphasize that the simulation results shown in figures 23 through 30 indicate only the effects on specific conductance as it is routed through the reservoirs as a conservative constituent using an assumed specific-conductance profile on May 1 . The same initial profile for each reservoir was used for each year simulated; in an actual reservoir, that may not occur.

The dilution effect of runoff on specific conductance in Rock Creek Reservoir is indicated by the upper half of the profiles in figure 23 . For example, in the simulation of 1957 , the specific conductance decreases from the assumed initial value of $90 \mu \mathrm{S} / \mathrm{cm}$ on May 1 to 60 to $70 \mu \mathrm{S} / \mathrm{cm}$ by July. When runoff volume is less, the dilution effect on specific conductance diminishes, as indicated by the profiles of 1972 and 1977 . The inflow stream water has little effect on specific conductance of the bottom water layers and of the outflow. The specific conductance of the outflow is only slightly less in 1957 than in 1977. The density differences that resulted from the temperature distribution inhibit mixing of the inflow water and the middle and bottom layers in the reservoir. The specific conductance of the withdrawal layers is relatively unaffected by the inflow, based on the simulation results.

The effect of runoff volume also is apparent in the simulation of specific conductance for Wolford Mountain Reservoir; however, the location of the outlet also affects the specific-conductance profiles. The deeper the outlet, the deeper the mixing of the inflow water in the reservoir. The effect of outlet level is more pronounced for years that had greater than normal runoff (compare simulations of 1984 to 1987). The greater than normal runoff during 1984 caused dilution of the entire reservoir with the outlet at $7,410 \mathrm{ft}$; the specific conductance decreased from an assumed initial value of $750 \mu \mathrm{S} / \mathrm{cm}$ on May 1 to about $350 \mu \mathrm{S} / \mathrm{cm}$ by July 1 (fig. 27). The effects of inflow water on the specific conductance in most years would be similar to results shown for simulation of 1976 (fig. 26). Outlet elevation did not have a large effect on outflow specific conductance for Wolford Mountain Reservoir. The dampening effect of the reservoir on instream specific conductance is evident for all the years simulated (figs. 29 and 30) but is most pronounced for the less than normal runoff years (1977 and 1987) when the dilution effect by runoff was diminished. 
The concentration profiles of dissolved solids and of conservative constituents in the proposed reservoirs and concentrations in the outflows likely would be similar qualitatively to the specific-conductance simulations. If that conclusion is valid, then there would be a dampening of dissolvedsolids concentrations in Rock and Muddy Creeks by the reservoirs. The release water could have larger dissolved-solids concentrations than the inflow water during spring runoff and smaller dissolved-solids concentrations than the inflow water during the rest of the year. The effects of the reservoirs on dissolved-solids concentrations and loads in Rock and Muddy Creeks could be quantitatively discussed if relations of dissolved-solids concentration to specific conductance were known. However, the effects of ground-water inflow, evaporation, and leaching on specific conductance and on dissolved-solids concentrations are not known with certainty prior to reservoir construction; therefore, quantitative estimates of dissolved-solids concentrations for the proposed reservoir sites were not done. The effects of ground water and leaching on dissolved-solids concentrations at Rock Creek Reservoir may not be important because the reservoir site is located on soil and outcrops derived from granite. Because of the presence of soil and outcrops derived from shale at the Wolford Mountain site, such an assumption for Wolford Mountain Reservoir may not be valid.

\section{Major Inorganic Constituents}

Information about ion concentrations and inorganic chemical composition in the proposed reservoirs can be examined with respect to the water quality of the inflowing streams, assuming that chemical reactions do not occur in the impounded waters that would change constituent concentrations. A summary of major inorganic-constituent and dissolved-solids concentrations is listed in table 7 for samples collected from Rock and Muddy Creeks. The mean concentrations usually are more representative of average conditions in the streams. That is especially true for sites where samples were collected on a regular schedule throughout the year; most of the samples represent base-flow conditions rather than snowmelt runoff conditions. The discharge-weighted means may be more representative of constituent concentrations in the proposed reservoirs because most of the flow in Rock and Muddy Creeks occurs during the snowmelt runoff period (usually a duration of about 3 months or less). The discharge-weighted means in table 7 were computed using the instantaneous stream discharge at the time of sample collection.

Constituent concentrations in the proposed reservoirs could be greater than the discharge-weighted mean. concentrations in the inflow water. Evaporation would increase dissolved-solids concentrations and, hence, most ion concentrations also. Leaching of soluble salts from the sides and bottom of the reservoirs could add dissolved ions into the reservoir water, especially after the initial filling of the reservoirs. Leaching of salts into reservoir water could be more important at the Wolford Mountain site than at the Rock Creek site because of the different geologic formations underlying the proposed reservoir sites. The effect of ground-water discharge on inorganic-constituent concentrations at the proposed reservoir sites is not known. 
Table 7.--Summary of major inorganic-constituent and dissolved-solids concentrations for samples collected from Rock and Muddy Creeks

[A11 constituents dissolved; all concentrations in milligrams per liter]

\begin{tabular}{cccccc} 
Constituent & $\begin{array}{c}\text { Number } \\
\text { of } \\
\text { samples }\end{array}$ & $\begin{array}{c}\text { Sample } \\
\text { mean }\end{array}$ & $\begin{array}{c}\text { Standard } \\
\text { deviation }\end{array}$ & Maximum & $\begin{array}{c}\text { Discharge- } \\
\text { weighted } \\
\text { mean }\end{array}$ \\
\hline
\end{tabular}

GAGING STATION 09060500, ROCK CREEK NEAR TOPONAS, SAMPLING PERIOD MARCH 1986 TO SEPTEMBER 1987

$\begin{array}{lccccrr}\text { Calcium } & 13 & 9.8 & 3.1 & 15 & 5.8 & 7.4 \\ \text { Magnesium } & 13 & 2.0 & .7 & 3.4 & .8 & 1.3 \\ \text { Sodium } & 13 & 2.7 & .6 & 4.0 & 1.9 & 2.2 \\ \text { Potassium } & 13 & .8 & .2 & 1.1 & .5 & .7 \\ \text { Alkalinity } & 13 & 34 & 11 & 53 & 18 & 25 \\ \text { Sulfate } & 13 & 6.6 & 2.7 & 11 & .6 & 6.2 \\ \text { Chloride } & 13 & .6 & .2 & 1.0 & .3 & .6 \\ \text { Fluoride } & 13 & .1 & .04 & .2 & .1 & .1 \\ \text { Silica } & 13 & 11 & 1.6 & 16 & 9.9 & 11 \\ \text { Dissolved } & 13 & 55 & 13 & 80 & 35 & 44 \\ \quad & & & & & & \end{array}$

GAGING STATION 09060550, ROCK CREEK AT CRATER, SAMPLING PERIOD DECEMBER 1984 TO OCTOBER 1987

$\begin{array}{lcccccr}\text { Calcium } & 33 & 18 & 5.0 & 26 & 7.7 & 12 \\ \text { Magnesium } & 33 & 3.6 & .9 & 4.9 & 1.7 & 2.6 \\ \text { Sodium } & 33 & 3.5 & .6 & 4.5 & 2.2 & 2.8 \\ \text { Potassium } & 33 & 1.0 & .3 & 1.5 & .5 & .8 \\ \text { Alkalinity } & 33 & 55 & 15 & 79 & 26 & 38 \\ \text { Sulfate } & 33 & 10 & 1.7 & 13 & 5.0 & 9.5 \\ \text { Chloride } & 33 & .9 & 1.0 & 6.4 & .4 & .8 \\ \text { Fluoride } & 33 & .1 & .04 & .2 & .1 & .1 \\ \text { Silica } & 33 & 13 & 1.7 & 15 & 9.5 & 12 \\ \text { Dissolved } & 33 & 83 & 16 & 100 & 47 & 64 \\ \quad \text { solids } & & & & & & \end{array}$

GAGING STATION 09041500, MUDDY CREEK AT KREMMLING, SAMPLING PERIOD MARCH 1985 TO SEPTEMBER 1987

\begin{tabular}{lcccccc} 
Calcium & 35 & 80 & 45 & 200 & 28 & 46 \\
Magnesium & 35 & 32 & 20 & 76 & 6.7 & 16 \\
Sodium & 35 & 36 & 23 & 92 & 7.7 & 18 \\
Potassium & 35 & 2.8 & 1.2 & 6.7 & 1.2 & 2.1 \\
Alkalinity & 34 & 139 & 46 & 222 & 70 & 101 \\
Sulfate & 35 & 264 & 178 & 690 & 45 & 117 \\
Chloride & 35 & 4.9 & 3.6 & 14 & .9 & 2.3 \\
Fluoride & 35 & .2 & .08 & .4 & .1 & .16 \\
Silica & 35 & 8.9 & 1.4 & 12 & 4.9 & 9.0 \\
Dissolved & 34 & 515 & 293 & 1,200 & 140 & 268 \\
$\quad$ & & & & & \\
\hline
\end{tabular}


The chemical composition of natural water often is classified according to the predominant cations and anions in the water. Constituent concentrations listed in table 7 need to be converted to chemical equivalent weights prior to determining the relative percentage of each ion in the water sample. All or nearly all of the alkalinity in Rock and Muddy Creeks is composed of bicarbonate ions at the measured $\mathrm{pH}$ of the samples. On the basis of water samples collected at the Toponas and Crater gages, Rock Creek has calcium bicarbonate water, and bicarbonate accounts for at least 70 to 80 percent of the anion concentration (as milliequivalents per liter). The chemical composition of Rock Creek does not seem to change substantially between base flow and runoff. It would be expected that water in Rock Creek Reservoir also would be composed primarily of calcium and bicarbonate ions. The presence of large areas of shale in the Muddy Creek basin not only affects the concentrations of dissolved ions in the stream but also affects the chemical composition. The chemical composition of samples collected during low-flow periods at the Muddy Creek gage usually was calcium sulfate bicarbonate, and samples had more sulfate than bicarbonate. The chemical composition of samples collected during high stream discharges was calcium bicarbonate sulfate, and samples had more bicarbonate than sulfate. Apparently, snowmelt runoff dilutes the sulfate concentrations more than the bicarbonate (or alkalinity) concentrations in Muddy Creek. The composition of water impounded in Wolford Mountain Reservoir would be calcium bicarbonate sulfate or calcium sulfate bicarbonate. This is a general classification because it is not possible to estimate exact proportions of dissolved ions in the reservoir water. If leaching of salts from the bottom and sides of the reservoir occurred, the water composition could be altered.

\section{Phosphorus and Nitrogen}

Phosphorus and nitrogen are essential nutrients for algal growth in lakes and reservoirs. Large input of nutrients to a water body can cause eutrophic conditions to develop, which can adversely affect fisheries, recreation, and water supplies. Estimates of phosphorus and nitrogen concentrations in the proposed Rock Creek and Wolford Mountain Reservoirs are needed to address eutrophication potential of the reservoirs.

Numerous empirical models have been developed for predicting total phosphorus in lakes and reservoirs. Many of these models were developed from data collected primarily from natural lakes in eastern North America and in Europe. Many of the models use annual phosphorus loading, lake morphometry, and hydraulic flushing rate to predict total-phosphorus concentrations in lakes. Considerable uncertainty may exist regarding the applicability of the phosphorus models to high altitude reservoirs in Colorado. Also, some models require information that can only be obtained from an actual water body and are not applicable to proposed reservoirs.

Two models for estimating total-phosphorus concentration in a reservoir that could be applicable to proposed reservoirs in Colorado were examined. Canfield and Bachmann (1981) developed a phosphorus model (hereinafter referred to as phosphorus model 1) from data collected at 433 reservoirs located throughout North America. That data set represents a broad range of morphometric, hydraulic, and limnological conditions; that range includes the 
morphometric and hydraulic characteristics of the proposed reservoirs. Totalphosphorus concentration is predicted from annual total-phosphorus load, annual mean reservoir depth, and hydraulic flushing rate. The second phosphorus model examined (hereinafter referred to as phosphorus model 2) was developed by Mueller (1982), who re-evaluated 5 commonly used phosphorus models by using data from 68 reservoirs located in the Western United States, including 6 reservoirs in Colorado. Mueller (1982) reported that the model with the smallest error that could be used for proposed reservoirs was a version of a model originally developed by Vollenweider (1976). In that model, total-phosphorus concentration is a function of areal phosphorusloading rate, mean depth, and hydraulic-retention time.

The two phosphorus models were tested using data collected during 1986 and 1987 from Williams Fork and Green Mountain Reservoirs. Two sets of samples were collected in 1986 and three sets were collected in 1987 at several locations and depths in each reservoir. Samples for total-phosphorus concentrations in the inflow were collected at the gaging stations previously described for each reservoir (fig. 1). The total-phosphorusloading and hydraulic data for each reservoir for each year are listed in table 8 . The annual total-phosphorus load was determined by dividing the water year into time intervals according to dates of collection of phosphorus samples. The total-phosphorus concentration of the sample collected in each time interval was assumed equal to the total-phosphorus concentration for each day in that interval. Adjustments to the intervals were made if stream discharge changed substantially. The average stream discharge then was used to compute the daily total-phosphorus loads, which are summed to give the totalphosphorus load for the year. Total-phosphorus load is converted to an areal loading rate (table 8 ) by dividing the annual total-phosphorus load by the average reservoir-surface area. The hydraulic-retention time is the reciprocal of the flushing rate.

Table 8.--Measured and predicted total-phosphorus concentrations for Willians Fork and Green Mountain Reservoirs, 1986 and 1987

(Areal phosphorus-loading rate, milligrans per square meter per year; flushing rate in year ${ }^{-1}$; wean depth, in meters; phosphorus models are: model 1 is based on Canfield and Bachmann (1981); model 2 is based on Mueller (1982); concentrations, in milligrams per liter; measured concentrations of total phosphorus are averages from two sets of samples collected in 1986 and three sets of samples collected in 1987]

\begin{tabular}{|c|c|c|c|c|c|c|c|c|c|}
\hline Reservoir & Year & $\begin{array}{c}\text { Areal } \\
\text { phosphorus- } \\
\text { loading } \\
\text { rate }\end{array}$ & $\begin{array}{l}\text { Flushing } \\
\text { rate }\end{array}$ & $\begin{array}{l}\text { Mean } \\
\text { depth }\end{array}$ & $\begin{array}{l}\text { Measured } \\
\text { total- } \\
\text { phosphorus } \\
\text { concen- } \\
\text { tration }\end{array}$ & $\begin{array}{l}\text { Phosphorus } \\
\text { Predicted } \\
\text { total- } \\
\text { phosphorus } \\
\text { concen- } \\
\text { tration }\end{array}$ & $\begin{array}{l}\text { model } 1 \\
\text { 95-percent } \\
\text { confidence } \\
\text { interval }\end{array}$ & $\begin{array}{l}\text { Phosphorus } \\
\text { Predicted } \\
\text { total- } \\
\text { phosphorus } \\
\text { concen- } \\
\text { tration }\end{array}$ & $\begin{array}{c}\text { odel } 2 \\
\begin{array}{c}95-p e r c e n t \\
\text { confidence } \\
\text { interval }\end{array}\end{array}$ \\
\hline $\begin{array}{l}\text { Willians } \\
\text { Fork }\end{array}$ & $\begin{array}{l}1986 \\
1987\end{array}$ & $\begin{array}{l}783 \\
577\end{array}$ & $\begin{array}{l}1.48 \\
1.13\end{array}$ & $\begin{array}{l}17.0 \\
16.8\end{array}$ & $\begin{array}{r}0.010 \\
.014\end{array}$ & $\begin{array}{r}0.018 \\
.017\end{array}$ & $\begin{array}{r}0.006-.052 \\
.005-.048\end{array}$ & $\begin{array}{r}0.013 \\
.017\end{array}$ & $\begin{array}{r}0.003-.062 \\
.004-.080\end{array}$ \\
\hline $\begin{array}{l}\text { Green } \\
\text { Mountain }\end{array}$ & $\begin{array}{l}1986 \\
1987\end{array}$ & $\begin{array}{r}1,399 \\
886\end{array}$ & $\begin{array}{l}4.42 \\
2.76\end{array}$ & $\begin{array}{l}19.3 \\
19.6\end{array}$ & $\begin{array}{l}.010 \\
.011\end{array}$ & $\begin{array}{l}.012 \\
.012\end{array}$ & $\begin{array}{l}.004-.036 \\
.004-.036\end{array}$ & $\begin{array}{l}.012 \\
.008\end{array}$ & $\begin{array}{l}.003-.057 \\
.002-.039\end{array}$ \\
\hline
\end{tabular}


LaBaugh (1985) reported a large error in estimating phosphorus load to Williams Fork Reservoir when using data collected only at gaging station 09037500. That study was a detailed analyses of errors associated with the water and phosphorus budgets for Williams Fork Reservoir from 1979 through 1982. For the drought year of 1981, when ungaged sources accounted for a greater proportion of the water budget, ungaged water sources accounted for 76 percent of the total-phosphorus load. Gaged stream discharge at station 09037500 in 1986 was similar to the gaged stream discharge in 1980 and 1982 when ungaged sources accounted for approximately 50 percent of the totalphosphorus load into the reservoir. Therefore, the computed total-phosphorus load at station 09037500 was assumed to have been 50 percent of the totalphosphorus load to Williams Fork Reservoir in 1986. The gaged stream discharge at station 09037500 in 1987 was considerably less than 1986 , so it was assumed that inflow from ungaged sources accounted for a greater proportion of the phosphorus load, as occurred in 1981. The computed total-phosphorus load at station 09037500 was assumed to be about 30 percent of the actual totalphosphorus load into Williams Fork Reservoir in 1987. The quantity of ungaged phosphorus input to Green Mountain Reservoir is not as well known. A study during 1976 at Green Mountain Reservoir (Eddy and Fox, 1976) reported that 18 percent of the total-phosphorus load into Green Mountain Reservoir was from direct tributary discharge. However, that study was based on a few samples collected during the fall. The total-phosphorus load into Green Mountain Reservoir for 1986 and 1987 was adjusted to account for tributary discharge into the reservoir downstream from gaging station 09053500. The total-stream discharge into Green Mountain Reservoir was computed from reservoir storage records and stream discharge records for the Blue River, Cataract Creek, and Black Creek. The total-phosphorus concentrations in the tributaries were assumed to be equal to total-phosphorus concentrations in the Blue River at gaging station 09053500. The computed total-phosphorus load at gaging station 09053500 was multiplied by 1.14 for 1986 and by 1.12 for 1987 . Those factors are ratios of the computed stream discharge into the reservoir divided by the gaged stream discharge at gaging station 09053500 for the year. Those adjustments may not account for potential sources of nutrients from the developed area along the west side of the reservoir.

Both models accurately replicated total-phosphorus concentrations in each reservoir for 1986 and 1987 (table 8); therefore, they were considered valid for estimating total-phosphorus concentrations at the proposed reservoirs. As evident in table 8, the 95-percent confidence intervals of the models were quite large; thus, a rather large uncertainty exists associated with the predicted concentrations for the proposed reservoirs.

Total-phosphorus concentrations at the proposed reservoirs were estimated only for years when samples were collected from Rock and Muddy Creeks (water years 1985, 1986, and 1987). Because antecedent conditions can affect the quantity of phosphorus exported from a watershed, phosphorus loads can vary from year to year. Therefore, phosphorus data collected during 1985-87 should only be used to estimate phosphorus loading for those years and should not be used to compute phosphorus loading for years when only discharge data were collected. The yearly variability of phosphorus export in Rock and Muddy Creek basins is not known; estimates of total-phosphorus concentrations for the reservoir sites were made only for years that had concurrent streamdischarge and phosphorus data. Phosphorus data for samples from Rock and 
Muddy Creeks are summarized in table 9. Total-phosphorus concentrations in Rock Creek were similar between the Toponas and Crater gages. On the basis of stream-discharge records for long-term gaging stations in the Upper Colorado River basin, greater than normal runoff occurred during 1985 and 1986 and less than normal runoff occurred during 1987 in Rock and Muddy Creeks.

Table 9.--Sumary of nutrient concentrations in saples collected from Rock and nudidy Creaks

[Concentrations, in milligrams per liter; nitrogen concentrations expressed as nitrogen; phosphorus concentrations expressed as phosphorus]

\begin{tabular}{|c|c|c|c|c|c|c|c|c|c|c|}
\hline Statistic & $\begin{array}{c}\text { Total } \\
\text { amonia } \\
\text { plus } \\
\text { organic } \\
\text { nitrogen }\end{array}$ & $\begin{array}{l}\text { Dissolved } \\
\text { awonia } \\
\text { plus } \\
\text { organic } \\
\text { nitrogen }\end{array}$ & $\begin{array}{c}\text { Total } \\
\text { ammonia }\end{array}$ & $\begin{array}{l}\text { Dissolved } \\
\text { amoonia }\end{array}$ & $\begin{array}{c}\text { Total } \\
\text { nitrite } \\
\text { plus } \\
\text { nitrate }\end{array}$ & $\begin{array}{l}\text { Dissolved } \\
\text { nitrite } \\
\text { plus } \\
\text { nitrate }\end{array}$ & $\begin{array}{c}\text { Total } \\
\text { phosphorus }\end{array}$ & $\begin{array}{l}\text { Dissolved } \\
\text { phosphorus }\end{array}$ & $\begin{array}{l}\text { Total } \\
\text { ortho- } \\
\text { phosphate }\end{array}$ & $\begin{array}{c}\text { Dissolved } \\
\text { ortho- } \\
\text { phosphate }\end{array}$ \\
\hline
\end{tabular}

GAGING STATION 09060500, ROCK CREEK NEAR TOPONAS, SAMPLING PERIOD MARCH 1986 TO October 1987

\begin{tabular}{|c|c|c|c|c|c|c|c|c|c|c|}
\hline $\begin{array}{l}\text { Nuber of } \\
\text { sapples }\end{array}$ & 14 & 8 & 14 & 8 & 14 & 9 & 14 & 8 & 14 & 10 \\
\hline $\begin{array}{l}\text { Median } \\
\text { Maximum } \\
\text { Mininua }\end{array}$ & $\begin{array}{l}0.35 \\
2.1 \\
<\quad .20\end{array}$ & $\begin{array}{l}0.35 \\
1.0 \\
.20\end{array}$ & $\begin{array}{c}0.015 \\
.10 \\
<.01\end{array}$ & $\begin{array}{r}0.025 \\
.05 \\
\times \quad .01\end{array}$ & $\begin{array}{r}<0.10 \\
.20 \\
.01\end{array}$ & $\begin{array}{r}<0.10 \\
.19 \\
.01\end{array}$ & $\begin{array}{l}0.03 \\
.09 \\
.01\end{array}$ & $\begin{array}{r}0.02 \\
.05 \\
.01\end{array}$ & $\begin{array}{r}0.01 \\
.02 \\
<.01\end{array}$ & $\begin{array}{r}<0.01 \\
.02 \\
<.01\end{array}$ \\
\hline
\end{tabular}

GAGING STATION 09060550, ROCK CREEK AT CRATER, SAMPLING PERIOD DECEMBER 1984 TO OCTOBER 1987

\begin{tabular}{|c|c|c|c|c|c|c|c|c|c|c|}
\hline Number of & 32 & 6 & 32 & 6 & 32 & 6 & 32 & 6 & 18 & 6 \\
\hline $\begin{array}{l}\text { Median } \\
\text { Maximum } \\
\text { Minimum }\end{array}$ & $\begin{array}{r}.30 \\
2.8 \\
<.20\end{array}$ & $\begin{array}{r}.50 \\
.90 \\
<.20\end{array}$ & $\begin{array}{r}.02 \\
.07 \\
<.01\end{array}$ & $\begin{array}{r}.02 \\
.05 \\
<.01\end{array}$ & $\begin{array}{r}<.10 \\
.30 \\
<.10\end{array}$ & $\begin{array}{r}<.10 \\
.25 \\
<.10\end{array}$ & $\begin{array}{r}.02 \\
.14 \\
<.01\end{array}$ & $\begin{array}{l}.025 \\
.05 \\
.01\end{array}$ & $\begin{array}{r}.01 \\
.03 \\
<.01\end{array}$ & $\begin{array}{r}<.01 \\
.02 \\
<.01\end{array}$ \\
\hline
\end{tabular}

GAGING STATION 09041500, MUDDY CREEK AT KREMALING, SAMPLING PERIOD MARCH 1985 TO OCTOBER 1987

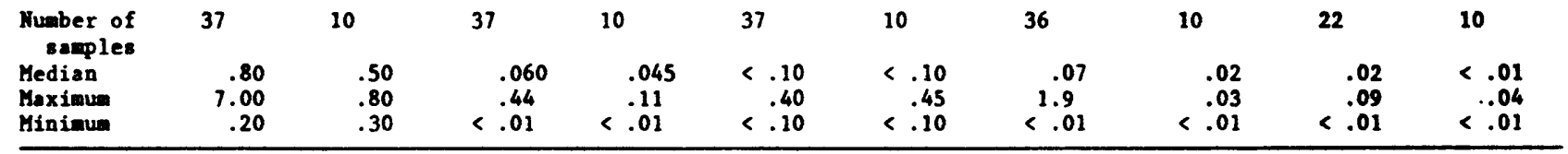

Simulated total-phosphorus concentrations for Rock Creek Reservoir ranged from 0.007 to $0.019 \mathrm{mg} / \mathrm{L}$ (table 10). The 95-percent confidence intervals of the simulated concentrations also are listed in table 10 . The areal phosphorus-loading rates and total-phosphorus concentrations for Rock Creek Reservoir were computed using 90 percent of the total-phosphorus load computed for the Crater gage. The total-phosphorus loads were computed for the Crater gage because daily stream discharge was recorded during 1985-87 at the Crater gage but not at the Toponas gage. Total-phosphorus loads computed for the Crater gage may overestimate total-phosphorus loads at the reservoir site if stream discharge at the Crater gage was substantially greater than stream discharge at the reservoir site. The Toponas and Crater gages were never operated concurrently. Comparison of instantaneous stream discharge measurements made at the Toponas gage during 1985-87 (in conjunction with sediment and water-quality sampling) to stream discharge recorded at the Crater gage indicates that stream discharge at the Toponas gage usually was at least 90 percent of the stream discharge at the Crater gage. Changing the annual total-phosphorus load for Rock Creek by 10 percent changes the simulated total-phosphorus concentration for the reservoir by only $0.002 \mathrm{mg} / \mathrm{L}$. 
Table 10.--simulated total-phosphorus concentrations in Rock Crook and Wolford Mountain Roservoira

(Areal phosphorus-loading rate, in milligrams per square meter per year; flushing rate in year ${ }^{-1}$; mean depth, in meters; phosphorus models are: model 1 is based on Canfield and Bachmann (1981); nodel 2 is based on Mueller (1982); concentrations, in milligrass per liter]

\begin{tabular}{|c|c|c|c|c|c|c|c|c|}
\hline \multirow[b]{2}{*}{ Reservoir } & \multirow[b]{2}{*}{ Year } & \multirow[b]{2}{*}{$\begin{array}{l}\text { Areal } \\
\text { phosphorus- } \\
\text { loading } \\
\text { rate }\end{array}$} & \multirow[b]{2}{*}{$\begin{array}{c}\text { Flushing } \\
\text { rate }\end{array}$} & \multirow[b]{2}{*}{$\begin{array}{r}\text { Mean } \\
\text { depth }\end{array}$} & \multicolumn{2}{|c|}{ Phosphorus oodel 1} & \multicolumn{2}{|c|}{ Phosphorus eodel 2} \\
\hline & & & & & $\begin{array}{l}\text { Simulated } \\
\text { total- } \\
\text { phosphorus } \\
\text { concen- } \\
\text { tration }\end{array}$ & $\begin{array}{l}95 \text {-percent } \\
\text { confidence } \\
\text { interval }\end{array}$ & $\begin{array}{l}\text { Simulated } \\
\text { total- } \\
\text { phosphorus } \\
\text { concen- } \\
\text { tration }\end{array}$ & $\begin{array}{c}\text { 95-percent } \\
\text { confidence } \\
\text { interval }\end{array}$ \\
\hline $\begin{array}{l}\text { Rock } \\
\text { Creek }\end{array}$ & $\begin{array}{l}1985 \\
1986 \\
1987\end{array}$ & $\begin{array}{l}377 \\
399 \\
194\end{array}$ & $\begin{array}{r}0.60 \\
.67 \\
.39\end{array}$ & $\begin{array}{l}14.3 \\
14.3 \\
14.0\end{array}$ & $\begin{array}{r}0.019 \\
.019 \\
.015\end{array}$ & $\begin{array}{r}0.006-.055 \\
.006-.055 \\
.005-.043\end{array}$ & $\begin{array}{r}0.011 \\
.011 \\
.007\end{array}$ & 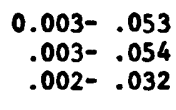 \\
\hline $\begin{array}{l}\text { Wolford } \\
\text { Mountain }\end{array}$ & $\begin{array}{l}1985 \\
1986 \\
1987\end{array}$ & $\begin{array}{l}5,365 \\
2,807 \\
2,324\end{array}$ & $\begin{array}{l}1.69 \\
1.85 \\
1.00\end{array}$ & $\begin{array}{l}12.4 \\
12.5 \\
12.0\end{array}$ & $\begin{array}{l}.075 \\
.049 \\
.055\end{array}$ & $\begin{array}{l}.023-.22 \\
.015-.14 \\
.017-.16\end{array}$ & $\begin{array}{l}.11 \\
.054 \\
.063\end{array}$ & $\begin{array}{l}.025-.52 \\
.012-.26 \\
.014-. .30\end{array}$ \\
\hline
\end{tabular}

Simulated total-phosphorus concentrations for Wolford Mountain Reservoir ranged from 0.049 to $0.11 \mathrm{mg} / \mathrm{L}$ for 1985-87 (table 10). As would be expected from a comparison of total-phosphorus concentrations in Rock and Muddy Creeks (table 9), the estimated total-phosphorus concentrations in Wolford Mountain Reservoir are larger than estimated total-phosphorus concentrations in Rock Creek Reservoir. The variability of phosphorus loading is evident in table 10 when the loading rates are compared for 1985 and 1986 for Muddy Creek. The areal phosphorus-loading rate was almost twice as great in 1985 as in 1986; yet there was about 11 percent more stream discharge in 1986 than in 1985 . Substantially more phosphorus may have been exported from the drainage basin in 1985 than in 1986. Also, phosphorus-loading rates computed by the method used for this study are dependent on the timing of sample collection, especially during the snowmelt runoff period in spring. The timing of sample collection in 1985 and 1986 may account for some of the difference in the loading rates for the 2 years. Total-phosphorus loads in Muddy Creek at the Wolford Mountain Reservoir site were assumed to be equal to total-phosphorus loads at the Muddy Creek gage.

Phosphorus concentrations often are used to evaluate trophic status of lakes and reservoirs. Carlson (1977) developed a numerical trophic-state index for total-phosphorus concentration, but that index is more meaningful for existing water bodies. Mueller (1982) describes a method (originally proposed by Reckhow, 1979) for determining the probability of accurately classifying the trophic state based on total-phosphorus concentration. The critical-phosphorus concentration used to separate eutrophic from noneutrophic water is $0.02 \mathrm{mg} / \mathrm{L}$, which is the concentration at which there is a 50-percent chance for development of eutrophic conditions. As an example, a total-phosphorus concentration of $0.019 \mathrm{mg} / \mathrm{L}$ for Rock Creek Reservoir (model 1 simulation for 1985 and 1986) corresponds to a 47-percent probability that Rock Creek Reservoir would be classified as eutrophic; a total-phosphorus concentration of $0.011 \mathrm{mg} / \mathrm{L}$ for Rock Creek Reservoir (model 2 simulation for 1985 and 1986) corresponds to a 21-percent probability. A total-phosphorus 
concentration of $0.007 \mathrm{mg} / \mathrm{L}$ for Rock Creek Reservoir (model 2 simulation for 1987) corresponds to 8-percent probability. All the total-phosphorus concentrations simulated for Wolford Mountain Reservoir correspond to greater than a 90-percent probability for eutrophy, based on a critical concentration of $0.02 \mathrm{mg} / \mathrm{L}$. It needs to be emphasized that such a classification is based on a total-phosphorus concentration of $0.02 \mathrm{mg} / \mathrm{L}$. Samples where dissolved- and total-phosphorus concentrations were determined indicate that much of the phosphorus in Muddy Creek is on suspended sediments. Once the water is impounded in a reservoir, much of the phosphorus could settle to the reservoir bottom. The eutrophication potential of Wolford Mountain Reservoir may be less than is indicated by total-phosphorus loading because of the cool water temperature and short hydraulic residence time of the reservoir (U.S. Forest Service, 1988).

Fewer models have been developed for estimating nitrogen than for estimating phosphorus in lakes and reservoirs. Bachmann (1981) adapted phosphorus models to total-nitrogen concentration. Bachmann's nitrogen models were developed for both natural lakes and reservoirs. Three models were developed for reservoirs: model 1 , which is based on volumetric nitrogen loading; model 2, which is based on areal nitrogen loading; and model 3, which is based on hydraulic flushing rate. These models predict a median, steady-state, total-nitrogen concentration. The models for reservoirs were tested using nitrogen data collected at Williams Fork and Green Mountain Reservoirs in 1986 and 1987. Total-nitrogen-loading data for each reservoir are listed in table 11. Total-nitrogen loads and loading rates were calculated by the same methods discussed for phosphorus loading, using total-nitrogen data collected at the inflow gaging stations at each reservoir. The assumptions discussed for estimating total-phosphorus loading to each reservoir also were applied to computation of total-nitrogen loads.

Table 11.--Nitrogen-loading data for Williams Fork and Green Mountain Reservoirs, 1986 and 1987

[Volumteric nitrogen-loading rate, in milligrams per cubic meter per year; areal nitrogen-loading rate, in milligrams per square meter per year; flushing rate, in year ${ }^{-1}$; mean depth, in meters]

\begin{tabular}{lccccc}
\hline Reservoir & Year & $\begin{array}{c}\text { Volumetric } \\
\text { nitrogen- } \\
\text { loading } \\
\text { rate }\end{array}$ & $\begin{array}{c}\text { Areal } \\
\text { nitrogen- } \\
\text { loading } \\
\text { rate }\end{array}$ & $\begin{array}{c}\text { Flushing } \\
\text { rate }\end{array}$ & $\begin{array}{c}\text { Mean } \\
\text { depth }\end{array}$ \\
\hline Williams Fork & 1986 & 851 & 14,419 & 1.48 & 17.0 \\
& 1987 & 1,110 & 18,655 & 1.13 & 16.8 \\
Green Mountain & 1986 & 2,167 & 41,829 & 4.42 & 19.3 \\
& 1987 & 1,774 & 34,840 & 2.76 & 19.6 \\
\hline
\end{tabular}

There were no large differences of estimated total-nitrogen concentrations among the three models (table 12). Measured total-nitrogen concentrations were within the 95-percent confidence intervals of the models for both 
reservoirs for 1986 and 1987. The estimated total-nitrogen concentrations for Green Mountain Reservoir for 1987 are about one-half the median concentration of samples collected in 1987 from the reservoir. Two sets of samples were collected in 1986 and three sets were collected in 1987 at several locations and depths in each reservoir. Therefore, the measured totalnitrogen concentrations listed in table 12 are based on rather sparse data. Model 2 consistently underestimates total-nitrogen concentrations; models 1 and 3 give nearly the same estimated concentrations, but model 1 has a smaller 95-percent confidence interval. Therefore, model 1 was used for simulation of total-nitrogen concentrations for the proposed reservoirs.

Table 12.--Measured and prodicted total-nitrogen concentrations in Williams Fork and Groen Mountain Reservoirs, 1986 and 1987

\begin{tabular}{|c|c|c|c|c|c|c|c|c|}
\hline \multicolumn{9}{|c|}{$\begin{array}{l}\text { [Concentrations, in ailligrams per liter; measured concentrations of total nitrogen are averages from } \\
\text { two sets of samples collected in } 1986 \text { and three sets of samples collected in 1987; nitrogen models } \\
\text { (Bachann, 1981) are: model } 1 \text { is based on volumetric nitrogen-loading rate; wodel } 2 \text { is based on } \\
\text { areal nitrogen-loading rate; and model } 3 \text { is based on hydraulic flushing rate] }\end{array}$} \\
\hline \multirow{2}{*}{ Reservoir } & \multirow{2}{*}{ Year } & \multirow{2}{*}{$\begin{array}{l}\text { Measured } \\
\text { total- } \\
\text { nitrogen } \\
\text { concentration }\end{array}$} & \multicolumn{3}{|c|}{$\begin{array}{l}\text { Predicted total-nitrogen } \\
\text { concentration }\end{array}$} & \multicolumn{2}{|c|}{ 95-percent confidence } & \multirow{2}{*}{$\frac{\text { interval }}{\text { Model } 3}$} \\
\hline & & & Mode1 1 & Model 2 & Model 3 & Model 1 & Model 2 & \\
\hline Williems Fork & $\begin{array}{l}1986 \\
1987\end{array}$ & $\begin{array}{r}0.40 \\
.65\end{array}$ & $\begin{array}{r}0.38 \\
.55\end{array}$ & $\begin{array}{r}0.29 \\
.39\end{array}$ & $\begin{array}{r}0.35 \\
.58\end{array}$ & $\begin{array}{r}0.15-.95 \\
.22-1.38\end{array}$ & $\begin{array}{r}0.12-.74 \\
.16-1.00\end{array}$ & $\begin{array}{r}0.13-1.14 \\
.21-1.87\end{array}$ \\
\hline Green Mountain & $\begin{array}{l}1986 \\
1987\end{array}$ & $\begin{array}{l}.33 \\
.80\end{array}$ & $\begin{array}{l}.38 \\
.45\end{array}$ & $\begin{array}{l}.29 \\
.33\end{array}$ & $\begin{array}{l}.35 \\
.43\end{array}$ & $\begin{array}{l}.15-.95 \\
.18-1.13\end{array}$ & $\begin{array}{l}.12-.74 \\
.13-.83\end{array}$ & $\begin{array}{l}.13-1.14 \\
.16-1.40\end{array}$ \\
\hline
\end{tabular}

The same assumptions and data-collection sites used to estimate totalphosphorus concentrations were used for estimating total-nitrogen concentrations for the proposed reservoirs. A summary of nitrogen concentrations in Rock and Muddy Creeks is listed in table 9. The simulated total-nitrogen concentrations for each proposed reservoir are listed in table 13 . On the basis of nitrogen data collected from 1985 to 1987 , total-nitrogen concentrations in Rock Creek Reservoir would be 0.3 to $0.4 \mathrm{mg} / \mathrm{L}$ and in Wolford Mountain Reservoir concentrations would be about $0.7 \mathrm{mg} / \mathrm{L}$. Trophic-state relations have been developed based on inorganic nitrogen concentrations, but the concentrations listed in table 13 represent total-nitrogen concentrations; therefore, the relations were not used. However, total-nitrogen concentrations can be used for addressing potential algal growth in the reservoirs, which is discussed later in this report.

\section{Dissolved Oxygen}

Dissolved-oxygen concentration in water is a function of temperature, dissolved-solids concentration, atmospheric pressure, and of numerous physical, chemical, and biological processes. Important processes that affect dissolved-oxygen concentrations in reservoirs include reaeration at the surface, turbulent transfer, photosynthesis, respiration, oxidation of organic matter, and oxidation of ammonia. 
Table 13.--Simulated total-nitrogen concentrations in Rock Creek and Wolford Mountain Reservoirs, 1985-87

[Volumetric nitrogen-loading rate, in milligrams per cubic meter per year; concentrations, in milligrams per liter]

\begin{tabular}{lcccc}
\hline Reservoir & Year & $\begin{array}{c}\text { Volumetric } \\
\text { nitrogen- } \\
\text { loading rate }\end{array}$ & $\begin{array}{c}\text { Simulated total- } \\
\text { nitrogen } \\
\text { concentration }\end{array}$ & $\begin{array}{c}95 \text {-percent } \\
\text { confidence } \\
\text { interval }\end{array}$ \\
\hline Rock Creek & 1985 & 437 & 0.39 & $0.16-1.00$ \\
& 1986 & 281 & .27 & $.11-.67$ \\
& 1987 & 306 & .38 & $.16-.97$ \\
Wolford & 1985 & 2,146 & .70 & $.29-1.78$ \\
Mountain & 1986 & 2,065 & .65 & $.27-1.64$ \\
& 1987 & 1,650 & .77 & $.31-1.94$ \\
\hline
\end{tabular}

An option exists in the water-quality routine of the temperature model (Adams, 1974) to simulate dissolved-oxygen concentration. The model assumes that biochemical oxygen demand (BOD) can be used to predict dissolved oxygen. $B O D$ in the inflow and initial BOD in the reservoir need to be specified to use the routine. BOD data were collected at the Williams Fork and Blue River gaging stations upstream from Williams Fork and Green Mountain Reservoirs in 1986 and 1987. BOD samples also were collected in each reservoir. Attempts to model dissolved oxygen using the water-quality routine were not satisfactory. Either the assumptions in that model were not valid for Williams Fork and Green Mountain Reservoirs or there were insufficient BOD data to use the model.

In thermally stratified reservoirs, decomposition of organic matter and respiration in the hypolimnion consumes dissolved oxygen, which is not easily replaced from the surface because of the density barrier caused by the thermal layers. Such a condition causes a depletion of dissolved oxygen in the hypolimnion during stratification. Unlike lakes, some oxygen-depleted water can be discharged from reservoirs depending on the location of outlets. During fall overturn, dissolved oxygen is resupplied to the hypolimnion. The depletion of dissolved oxygen in the hypolimnion commonly is expressed as an areal hypolimnetic oxygen deficit (AHOD) as described in Hutchinson (1957). The AHOD concept was introduced to enable comparison of oxygen deficits among lakes that have different morphometry. AHOD actually is an oxygen-depletion rate per unit area of the hypolimnion. Cornett and Rigler (1980) indicate that AHOD is correlated with trophic indicators such as total-phosphorus concentration, phytoplankton productivity, and Secchi-disk depth, and that the empirical models were improved when lake depth was included as a variable. The model that relates AHOD to total-phosphorus concentration (mean summer concentration in the euphotic zone) and to mean depth was tested using data from Williams Fork and Green Mountain Reservoirs. Measured AHOD was computed by the method described in Cornett and Rigler (1980) using the dissolvedoxygen profiles measured at each reservoir. The measured AHOD was compared 
to the predicted AHOD, and, with the exception of the prediction for Williams Fork Reservoir for 1987, model results were less than desirable. The results for Williams Fork and Green Mountain Reservoirs indicated that problems could occur when applying the AHOD model to reservoirs in the study area. In addition, much uncertainty could be associated with estimating AHOD and dissolvedoxygen concentrations for the proposed reservoirs because the estimates would be based entirely on simulated data. Simulated total-phosphorus concentrations would be used to compute the AHOD value. To determine dissolved-oxygen concentrations from the AHOD value, the temperature simulations would be needed to determine the thickness of the hypolimnion and length of the stratification period for each season simulated. Considerable uncertainty may be introduced in such determinations using simulated data, and several other chemical and biological variables could affect dissolved oxygen in reservoirs; therefore, simulation of dissolved-oxygen concentrations for the proposed reservoirs was not done.

One method for obtaining general information about dissolved-oxygen concentrations in proposed reservoirs is to examine dissolved-oxygen data for reservoirs in the same geographical area. Minimum dissolved-oxygen concentrations measured at Williams Fork Reservoir were $3.6 \mathrm{mg} / \mathrm{L}$ in 1986 and $2.9 \mathrm{mg} / \mathrm{L}$ in 1987, and minimum concentrations at Green Mountain Reservoir were $5.0 \mathrm{mg} / \mathrm{L}$ in 1986 and $2.7 \mathrm{mg} / \mathrm{L}$ in 1987 . Those data are representative of dissolvedoxygen concentrations near the reservoir bottoms in late summer when the reservoirs were thermally stratified, except for Green Mountain Reservoir in 1986. The minimum concentrations were determined from six measured profiles of dissolved oxygen at each reservoir for the two sampling seasons (May to October), and the dissolved oxygen at maximum depths was not always measured. Actual minimum dissolved-oxygen concentrations may have been less than the measured concentrations. However, the measured dissolved-oxygen data indicate that dissolved-oxygen concentrations can be about $3 \mathrm{mg} / \mathrm{L}$ in the deep layers of thermally stratified reservoirs in the study area. BOD data (5- and 20-day determinations) were collected at the Toponas and Muddy Creek gages during 1986 and 1987. The results are summarized in table 14. The larger BOD concentrations for Muddy Creek infer that greater potential exists for dissolvedoxygen consumption in water from Muddy Creek than in water from Rock Creek. It is not known if such an inference can be applied to impounded water from each stream.

\section{Algal Biomass}

Substantial algal growth can cause water-quality problems in a reservoir. Algal blooms can detract from recreational and esthetic value, cause odor and taste problems, and be toxic to animals. As algae die and sink through the water column their decomposition uses dissolved oxygen, which can deplete dissolved oxygen in the hypolimnion. Many species of algae occur, but the bluegreen algae often are of primary concern relating to water-quality problems.

Chlorophyll-a (all subsequent references to chlorophyll-a will be as chlorophyll) concentrations often are used as a general indicator of algal biomass. Numerous empirical relations of chlorophyll concentration to totalphosphorus concentration in lakes have been developed. Phosphorus concentration is only one of several variables that affect algal biomass in lakes. 
Table 14.--Biochemical-oxygen-demand data collected in 1986 and 1987 at gaging stations 09060500, Rock Creek near Toponas and 09041500, Muddy Creek at Kremmling

[Stream discharge, in cubic feet per second; biochemical oxygen demand (BOD), in milligrams per liter]

\begin{tabular}{|c|c|c|c|}
\hline $\begin{array}{l}\text { Date of } \\
\text { sample }\end{array}$ & Stream discharge & 5-day BOD & 20-day BOD \\
\hline
\end{tabular}

GAGING STATION 09060500, ROCK CREEK NEAR TOPONAS

$\begin{array}{lrrr}04-24-86 & 33 & 1.15 & 2.25 \\ 05-12-86 & 182 & 2.20 & 3.80 \\ 06-09-86 & 219 & .90 & 2.55 \\ 07-29-86 & 14 & .60 & 1.25 \\ 04-27-87 & 107 & 1.20 & 3.85 \\ 06-02-87 & 57 & .60 & 1.50 \\ 06-23-87 & 20 & .55 & 1.25 \\ 08-17-87 & 7.0 & .90 & 2.00\end{array}$

GAGING STATION 09041500, MUDDY CREEK AT KREMMLING

$\begin{array}{lrll}04-24-86 & 540 & 4.10 & 7.20 \\ 05-13-86 & 596 & 2.70 & 5.40 \\ 06-09-86 & 389 & 1.30 & 3.35 \\ 07-30-86 & 39 & 1.30 & 2.90 \\ 04-28-87 & 440 & 1.05 & 3.40 \\ 06-02-87 & 101 & 1.20 & 3.20 \\ 06-23-87 & 29 & 1.30 & 3.20 \\ 08-17-87 & 13 & 2.70 & 5.80\end{array}$

Some studies have attempted to incorporate total-nitrogen concentration (Smith, 1982) and inorganic suspended solids (Hoyer and Jones, 1983) into chlorophyll models. LaBaugh and Winter (1984) reported that measured chlorophyll concentrations in Williams Fork Reservoir in 1979 and 1980 were within the 95-percent confidence intervals predicted by a model from Dillon and Rigler (1974b). That model and three other models were examined for possible use for estimating chlorophyll concentrations for the proposed reservoirs. Chlorophyll data were collected in 1987 at Williams Fork and Green Mountain Reservoirs to test chlorophyll models. The mean chlorophyll concentration was determined from composite euphotic-zone samples collected in May, July, and August.

The model of Dillon and Rigler (1974b), hereinafter referred to as chlorophyl1 model 1 , predicts average summer chlorophyll concentration from the total-phosphorus concentration at spring overturn. Comparison of measured and predicted chlorophyll concentrations are listed in table 15 . The difference between measured and predicted chlorophyll concentrations for Williams 
Fork Reservoir is small, but the measured chlorophyll concentration at Green Mountain Reservoir was at the upper limit of the 95-percent confidence interval of the predicted value.

Table 15.--Measured and predicted chlorophyll-a concentrations using chlorophyll model 1 for Williams Fork and

Green Mountain Reservoirs, 1987

[Chlorophyll model 1 is based on Dillon and Rigler (1974b); all concentrations are in micrograms per liter, which correspond to the units used in the model; measured total-phosphorus concentration is the concentration in each reservoir in May]

\begin{tabular}{lcccc}
\hline Reservoir & $\begin{array}{c}\text { Total-phosphorus } \\
\text { concentration }\end{array}$ & $\begin{array}{c}\text { Measured } \\
\text { chlorophyll-a } \\
\text { concentration }\end{array}$ & $\begin{array}{c}\text { Predicted } \\
\text { chlorophyll-a } \\
\text { concentration }\end{array}$ & $\begin{array}{c}95 \text {-percent } \\
\text { confidence } \\
\text { interval }\end{array}$ \\
\hline Williams Fork & 8.3 & 2.7 & 1.6 & $0.6-4.3$ \\
Green Mountain & 9.8 & 5.5 & 2.0 & $.7-5.5$ \\
\hline
\end{tabular}

Two models from Hoyer and Jones (1983) were tested for possible use for estimating chlorophyll concentrations. Those models were developed from data collected from 96 reservoirs in the Midwestern United States. One model (hereinafter referred to as chlorophyll model 2) predicts summer chlorophyll concentrations from seasonal total-phosphorus concentration (generally May to August). The other model (chlorophyll model 3) predicts summer chlorophyll concentrations from seasonal total-phosphorus and inorganic suspended-solids concentrations. Inorganic suspended solids in impounded water can decrease chlorophyll yield because of possible decrease in light needed for photosynthesis. Chlorophyll concentrations predicted from phosphorus data were less reliable for reservoirs that had substantial nonalgal turbidity (Hoyer and Jones, 1983); they report that reservoirs that had ratios of inorganic suspended solids to total-phosphorus concentrations (ISS:TP) greater than 0.13 had less chlorophyll than was predicted by total-phosphorus concentration. More chlorophyll occurred in reservoirs that had ISS:TP less than 0.13 . Measured chloroph11 concentrations were within the 95-percent confidence intervals of the predicted chlorophyll concentrations for chlorophyll models 2 and 3 (table 16). The measured chlorophyll concentration in Williams Fork Reservoir was at the lower end of the confidence interval for both models. The measured chlorophyll concentration in Green Mountain Reservoir was at the upper end of the confidence interval for chlorophyll model 3.

Chlorophyll model 4 (Smith, 1982) predicts chlorophyll concentration from the mean total-phosphorus and total-nitrogen concentrations in the water body from May through September. For Smith's data, the model gave better chlorophyll predictions for lakes where the ratio, by weight, of totalnitrogen to total-phosphorus concentrations (TN:TP) is less than 35. Totalnitrogen concentration had a substantial effect on chlorophyll concentration 
Table 16.--Measured and predicted chlorophyll-a concentrations using chlorophyll aodels 2, 3, and for for Williams Fork and Groen Mountain Reservoirs, 1987

\begin{tabular}{|c|c|c|c|c|c|c|c|c|c|}
\hline \multirow{2}{*}{ Reservoir } & \multirow{2}{*}{$\begin{array}{c}\text { Total- } \\
\text { phosphorus } \\
\text { concentration }\end{array}$} & \multirow{2}{*}{$\begin{array}{l}\text { Inorganic } \\
\text { suspended- } \\
\text { solids } \\
\text { concen- } \\
\text { tration }\end{array}$} & \multirow{2}{*}{$\begin{array}{r}\text { Total- } \\
\text { nitrogen } \\
\text { concen- } \\
\text { tration }\end{array}$} & \multirow{2}{*}{$\begin{array}{l}\text { Measured } \\
\text { chloro- } \\
\text { phyll-a } \\
\text { concen- } \\
\text { tration }\end{array}$} & \multicolumn{3}{|c|}{$\begin{array}{c}\text { Predicted chlorophyll-a } \\
\text { concentration }\end{array}$} & \multicolumn{2}{|c|}{$\begin{array}{c}\text { 95-percent confidence } \\
\text { interval }\end{array}$} \\
\hline & & & & & Model 2 & Model 3 & Model 4 & Model 2 & Hodel 3 \\
\hline $\begin{array}{l}\text { Williams } \\
\text { Fork }\end{array}$ & 21 & 6.8 & 709 & 2.7 & 7.3 & 4.9 & 8.1 & $2.3-22$ & $1.8-14$ \\
\hline $\begin{array}{l}\text { Green } \\
\text { Mountain }\end{array}$ & 14 & 7.3 & 707 & 5.5 & 4.6 & 1.9 & 6.2 & $1.5-14$ & $.7-5.5$ \\
\hline
\end{tabular}

when TN:TP was less than 35 . The TN:TP ratio for the simulated totalphosphorus and total-nitrogen concentrations in Wolford Mountain Reservoir were less than 35. Comparisons of chlorophyll concentrations predicted by model 4 to the chlorophyll concentrations measured in Williams Fork and Green Mountain Reservoirs are listed in table 16. The error estimate for the model was not stated in Smith (1982), and the 95-percent confidence intervals could not be determined.

Simulated chlorophyll concentrations using models 1,2 , and 4 are listed in table 17 for the proposed reservoirs. Table 18 lists simulated chlorophyl1 concentrations using model 3 at a range of inorganic suspended-solids concentrations. The nutrient concentrations are the simulated concentrations listed in tables 10 and 13 . The total-phosphorus concentration used to simulate chlorophyll concentration was the average of the concentrations simulated by the two phosphorus models. Chlorophyll concentrations simulated by using models 1,2 , and 4 ranged from 2.4 to $4.9 \mu \mathrm{g} / \mathrm{L}$ chlorophyll in Rock Creek Reservoir. Those chlorophyll concentrations are similar to chlorophyll concentrations measured at Williams Fork Reservoir in 1979 and 1980 (LaBaugh and Winter, 1984) and the chlorophyll concentrations measured in 1987 at Williams Fork and Green Mountain Reservoirs. Chlorophyll model 3 (table 18) estimates less chlorophyl1 in Rock Creek Reservoir than models 1, 2, and 4 with inorganic suspended-solids concentrations of $5 \mathrm{mg} / \mathrm{L}$ or greater. The range of total-suspended solids (inorganic plus volatile suspended solids) concentrations for eight samples collected from Rock Creek in 1987 was 1 to $9 \mathrm{mg} / \mathrm{L}$. Water impounded in a reservoir on Rock Creek probably would not have inorganic suspended-solids concentrations greater than $5 \mathrm{mg} / \mathrm{L}$ for extended periods; therefore, inorganic suspended solids probably would not have a large effect on chlorophyll concentrations in the reservoir.

Variation in estimates of chlorophyll concentration for Wolford Mountain Reservoir depended on the chlorophyll model used and the year simulated (table 17). Models based solely on total-phosphorus concentration (models 1 and 2) predict rather large concentrations of chlorophyll (21 to $51 \mu \mathrm{g} / \mathrm{L})$. The error estimate (95-percent confidence interval) for the chlorophyll models (models 1,2 , and 4) are large. There was a substantial effect of small TN:TP ratios 
Table 17.--simulated chlorophyll-a concentrations using chlorophyll nodels 1,2 , and 4 for Rock Creek and Wolford Nountain Reservoirs, 1985-87

[Chlorophyll models are: Chlorophyll model 1 is based on Dillon and Rigler (1974b); Chlorophyll idel 2 is based on Hoyer and Jones (1983); Chlorophyll model 4 is based on Saith (1982); all concentrations, in micrograms per liter, which correspond to the. units used in the models; total-phosphorus concentrations are averages of simulated concentrations in table 10; total-nitrogen concentrations are simulated concentrations from table 13]

\begin{tabular}{|c|c|c|c|c|c|c|c|c|}
\hline \multirow{2}{*}{ Reservoir } & \multirow{2}{*}{ Year } & \multirow{2}{*}{$\begin{array}{c}\text { Total- } \\
\text { phosphorus } \\
\text { concen- } \\
\text { tration }\end{array}$} & \multirow{2}{*}{$\begin{array}{c}\text { Total- } \\
\text { nitrogen } \\
\text { concen- } \\
\text { tration }\end{array}$} & \multicolumn{3}{|c|}{$\begin{array}{c}\text { Simulated chlorphly11-a } \\
\text { concentration }\end{array}$} & \multicolumn{2}{|c|}{$\begin{array}{c}\text { 95-percent confidence } \\
\text { interval }\end{array}$} \\
\hline & & & & Model 1 & Model 2 & Model 4 & Model 1 & Mode1 2 \\
\hline $\begin{array}{l}\text { Rock } \\
\text { Creek }\end{array}$ & $\begin{array}{l}1985 \\
1986 \\
1987\end{array}$ & $\begin{array}{l}15 \\
15 \\
11\end{array}$ & $\begin{array}{l}390 \\
270 \\
380\end{array}$ & $\begin{array}{l}3.7 \\
3.7 \\
2.4\end{array}$ & $\begin{array}{l}4.9 \\
4.9 \\
3.4\end{array}$ & $\begin{array}{l}4.7 \\
3.8 \\
3.8\end{array}$ & $\begin{array}{l}1.3-10 \\
1.3-10 \\
.9-6.6\end{array}$ & $\begin{array}{l}1.6-15 \\
1.6-15 \\
1.1-10\end{array}$ \\
\hline $\begin{array}{l}\text { Wol ford } \\
\text { Hountain }\end{array}$ & $\begin{array}{l}1985 \\
1986 \\
1987\end{array}$ & $\begin{array}{l}92 \\
52 \\
59\end{array}$ & $\begin{array}{l}700 \\
650 \\
770\end{array}$ & $\begin{array}{l}51 \\
22 \\
27\end{array}$ & $\begin{array}{l}40 \\
21 \\
24\end{array}$ & $\begin{array}{l}21 \\
14 \\
17\end{array}$ & $\begin{array}{l}18-138 \\
8.1-60 \\
9.7-73\end{array}$ & $\begin{array}{l}13-123 \\
6.6-63 \\
7.6-73\end{array}$ \\
\hline
\end{tabular}

on simulated chlorophyll concentrations because model 4 estimated less chlorophyll than models 1 or 2, especially for 1985 (table 17) when totalphosphorus loading was large. TN:TP ratios for the 3 years simulated were less than 35 for Wolford Mountain Reservoir. Chlorophyll concentrations simulated by models 3 and 4 were similar if inorganic suspended-solids concentration was $25 \mathrm{mg} / \mathrm{L}$ (table 18) in Wolford Mountain Reservoir. Inorganic suspended solids may be an important variable in determining algal growth in Wolford Mountain Reservoir because suspended-sediment concentrations in Muddy Creek often are large during spring runoff. Chlorophyll concentrations estimated by model 3 with inorganic suspended-solids concentrations of 5 $\mathrm{mg} / \mathrm{L}$ and $10 \mathrm{mg} / \mathrm{L}$ were similar to chlorophyll concentrations estimated by models 1 and 2. All the chlorophyll models incorporate the simulated totalphosphorus concentration for estimating chlorophyll in the reservoir. Because a substantial fraction of the phosphorus could settle out of the euphotic zone and not be immediately available as a nutrient source for algal growth, the simulated chlorophyll concentrations may be overestimated by these models. Some particulate phosphorus could be re-introduced into the euphotic zone if nutrient recycling occurred. Also, algal growth, and subsequently chlorophyll concentrations, in Wolford Mountain Reservoir could be less than is indicated by nutrient concentrations because of the cool water temperature and short hydraulic residence time of the reservoir (U.S. Forest Service, 1988).

One variable not considered by the chlorophyll models used for simulation purposes is zooplankton grazing, which can be an important factor controlling algal biomass in lakes and reservoirs. It is possible to have less algal growth than expected, based solely on the nutrient input into a reservoir, because of zooplankton grazing on the algae (Shapiro, 1978).

Chlorophyll concentrations may give a general indication of algal biomass but may not give much information about the species of algae that might be expected to grow in the water. The blue-green species of algae are of primary concern because they can contribute to eutrophication problems. For example, sudden and large surface blooms of blue-green algae can occur. 
Table 18.--Simulated chlorophy11-a concentrations using chlorophyll model 3 for Rock Creek and Wolford Mountain Reservoirs, 1985-87

[Chlorophyll model 3 is based on Hoyer and Jones (1983); concentrations of total phosphorus and chlorophyll-a, in micrograms per liter; inorganic suspended solids, in milligrams per liter; total-phosphorus concentrations are averages of simulated concentrations in table 10]

\begin{tabular}{|c|c|c|c|c|}
\hline Year & $\begin{array}{l}\text { Total- } \\
\text { phosphorus } \\
\text { concen- } \\
\text { tration }\end{array}$ & $\begin{array}{l}\text { Inorganic } \\
\text { suspended- } \\
\text { solids } \\
\text { concen- } \\
\text { tration }\end{array}$ & $\begin{array}{c}\text { Simulated } \\
\text { chlorophyll-a } \\
\text { concen- } \\
\text { tration }\end{array}$ & $\begin{array}{c}\text { 95-percent } \\
\text { confidence } \\
\text { interval }\end{array}$ \\
\hline
\end{tabular}

ROCK CREEK RESERVOIR

\begin{tabular}{llrcc}
1985 & 15 & 5 & 3.3 & $1.2-9.3$ \\
and & 15 & 10 & 1.5 & $.5-4.2$ \\
1986 & 15 & 25 & .1 & $.05-.4$ \\
& & 5 & 1.7 & $.6-4.8$ \\
1987 & 11 & 10 & .6 & $.2-1.6$ \\
& 11 & 25 & .02 & $.01-.06$ \\
\hline
\end{tabular}

WOLFORD MOUNTAIN RESERVOIR

\begin{tabular}{rrrrr}
1985 & 92 & 5 & 49 & $18-138$ \\
& 92 & 10 & 43 & $16-121$ \\
& 92 & 25 & 29 & $11-82$ \\
1986 & 52 & 5 & 23 & $8.4-66$ \\
& 52 & 10 & 19 & $6.7-52$ \\
& 52 & 25 & 9.4 & $3.4-26$ \\
1987 & 59 & 5 & 28 & 10 \\
& 59 & 10 & 23 & $8.2-64$ \\
& 59 & 25 & 12 & $4.5-35$ \\
\hline
\end{tabular}

Reckhow and Simpson (1980) developed a method to estimate the probability of blue-green algal dominance based on data collected at 68 lakes in the NorthCentral and Northeastern United States. The method is not applicable to water bodies that have alkalinity less than $56 \mathrm{mg} / \mathrm{L}$. The probability of blue-green algal dominance depends on total-phosphorus loading, inorganic nitrogen concentration, and hydraulic residence time. Alkalinity is expected to be less 
than $56 \mathrm{mg} / \mathrm{L}$ in impounded water from Rock Creek; therefore, the method cannot be applied to Rock Creek Reservoir. Water impounded from Muddy Creek is expected to have alkalinity greater than $56 \mathrm{mg} / \mathrm{L}$. The method uses median inlake inorganic nitrogen concentrations, which for a proposed reservoir are not known. Yahnke (1981) used instream values for the inorganic nitrogen concentrations to estimate the probability of blue-green algal dominance for a proposed reservoir in Nebraska, but acknowledged that this may cause underestimates of the probability. Applying nitrogen and phosphorus data collected in 1985 to 1987 from Muddy Creek to the probability function results in greater than 90-percent probability for blue-green algal dominance in Wolford Mountain Reservoir. This conclusion should be used with caution because of uncertainty associated in using the probability function with simulated data for a proposed reservoir.

The potential algal productivity in natural water can be examined by use of algal-growth potential (AGP) tests. AGP tests are done on filtered water samples by adding known concentrations of nutrients to subsamples and measuring the quantity of biomass of a test alga after a certain time period. The algal growth of the spiked samples can be compared to the algal growth of a control (unspiked sample). AGP tests can provide information about changes in algal biomass that could occur if nutrient input into Rock or Muddy Creeks changed. The AGP tests done on inflow streams should not be directly extrapolated to indicate how algae in the impounded water will respond to changes in nutrient concentrations. AGP results can indicate if concentrations of some nutrients are sufficiently small to limit algal growth.

AGP samples were collected from Rock and Muddy Creek in late April (runoff), mid-July (summer growth period), and mid-September (fall base flow) in 1987. Results are shown in figure 31 for samples collected at the Toponas gage and in figure 32 for samples collected at the Muddy Creek gage.

Some additional algal growth occurred in the sample from Rock Creek collected in April when $0.03 \mathrm{mg} / \mathrm{L}$ of phosphorus was added, but minimal additional growth occurred when more phosphorus was added. Phosphorus had no effect on algal growth in the sample collected in July, and a small increase in algal growth occurred when $0.15 \mathrm{mg} / \mathrm{L}$ of phosphorus was added to the sample collected in September. The implication is that a large increase in phosphorus concentration in Rock Creek does not indicate that algal growth would increase substantially in stream water. In the three samples, substantial algal growth occurred when nitrogen was added, which indicates that algal growth in water from Rock Creek may be limited by availability of nitrogen. Although totalnitrogen concentrations in water samples from Rock Creek often were at least $0.3 \mathrm{mg} / \mathrm{L}$, much of the total nitrogen is organic nitrogen. Inorganic nitrogen as nitrite plus nitrate concentrations are small (table 9); therefore, insufficient nitrogen may be available as a nutrient source for organisms in the water. Nitrogen-limiting water can affect the probability of blue-green algal dominance, and some blue-green algae may become the dominant algal species at small nitrogen concentrations.

The sample collected in April from Muddy Creek had additional algal growth compared to the control when $0.03 \mathrm{mg} / \mathrm{L}$ of phosphorus was added; no additional growth occurred until nitrogen was added. Although the totalphosphorus concentration in the sample collected on April 28 was $0.07 \mathrm{mg} / \mathrm{L}$, 


\section{EXPLANATION}

NUTRIENT ADDITION, IN MILLIGRAMS PER LITER

UII CONTROL 0.03 PHOSPHORUS 0.15 PHOSPHORUS 0.50 PHOSPHORUS

0.50 PHOSPHORUS PLUS 0.50 NITROGEN
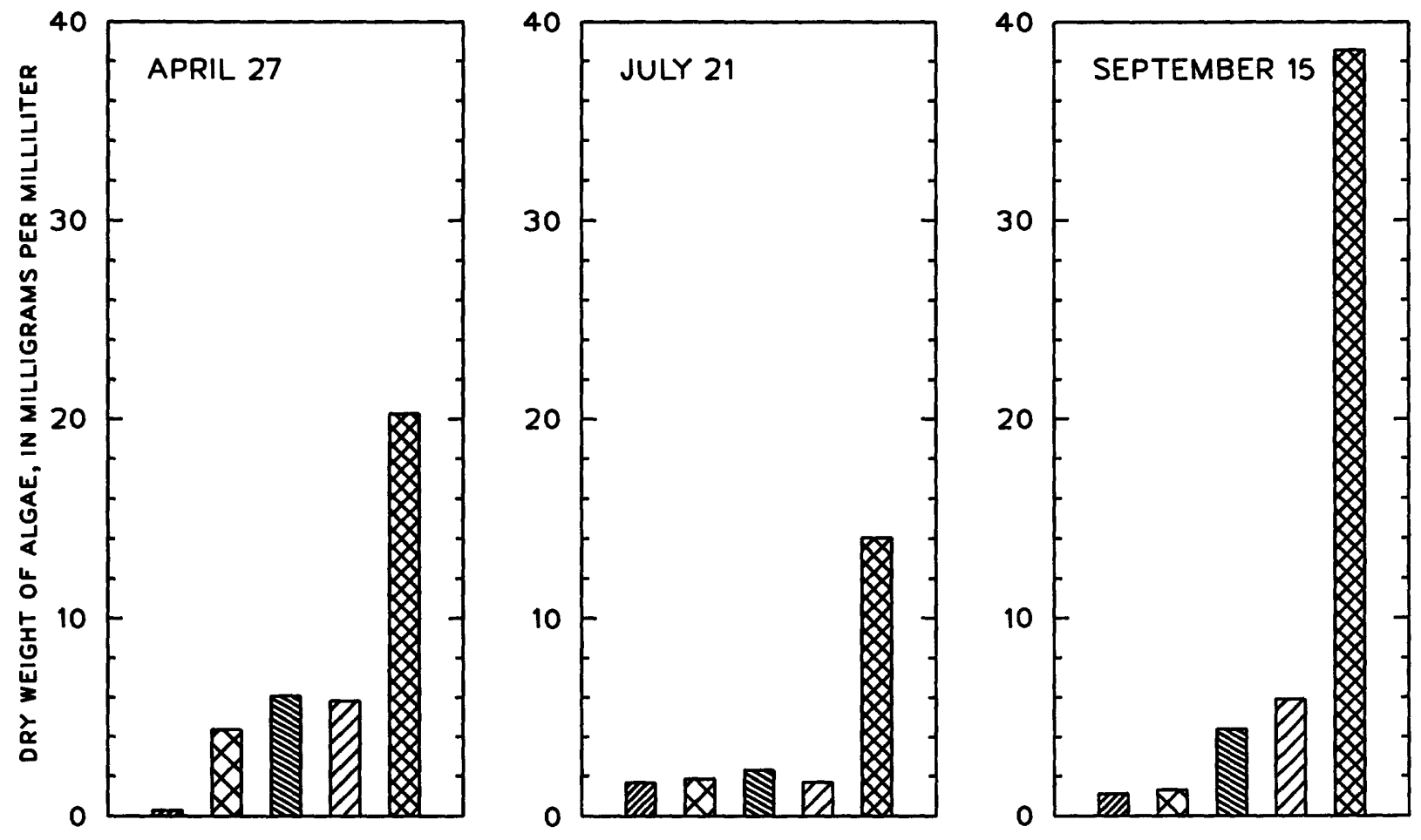

Figure 31.--Results of algal-growth-potential analyses for Rock Creek near Toponas, 1987. 
EXPLANATION

NUTRIENT ADDITION, IN MILLIGRAMS PER LITER

UII CONTROL 0.03 PHOSPHORUS 0.15 PHOSPHORUS 0.50 PHOSPHORUS 0.50 PHOSPHORUS PLUS 0.50 NITROGEN
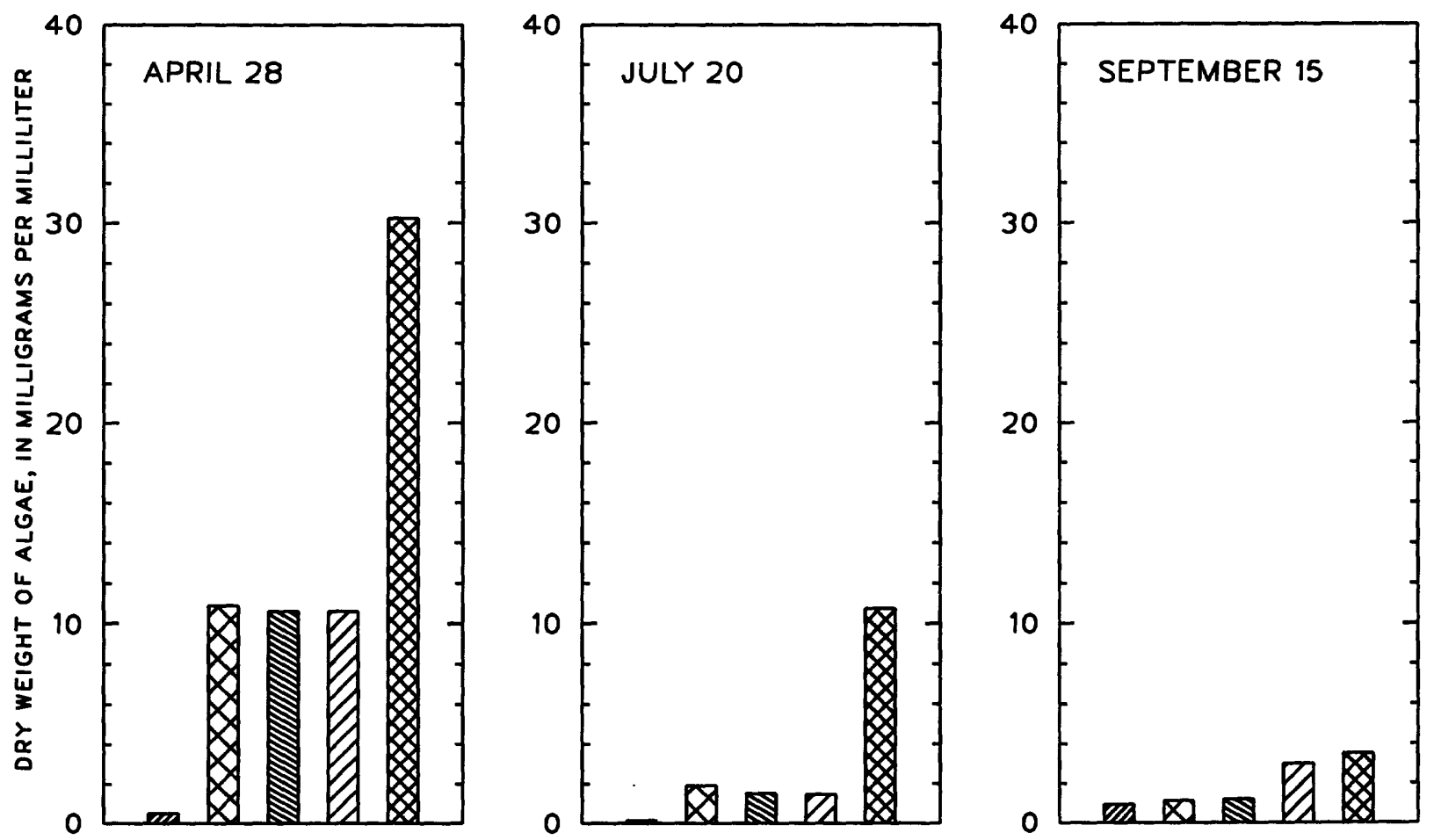

Figure 32.--Results of algal-growth-potential analyses for Muddy Creek at Kremmling, 1987. 
the suspended phosphorus was removed during filtering of the water sample for the AGP test. Therefore, increased growth of the test alga occurred when $0.03 \mathrm{mg} / \mathrm{L}$ of phosphorus was added. An increase by a factor of three occurred in algal growth when nitrogen was added, which indicates that insufficient nitrogen may have been available for algal growth in the water sample. The AGP results for the sample collected in July from Muddy Creek are similar to the AGP results for the sample collected in July from Rock Creek. Some algal-growth response occurred when $0.03 \mathrm{mg} / \mathrm{L}$ phosphorus was added, but substantial additional growth occurred when nitrogen was added. Much less algal growth occurred in the sample collected in September from Muddy Creek than in the samples collected in April and July. Reasons for lack of algal growth are not clear. One possible explanation is that the salinity in Muddy Creek may have been at a critical level for the test alga (Selenastrum capricornutum) and inhibited its growth (Chadwick and Associates, Littleton, Colorado, oral commun., 1987). Other possible reasons are that a chemical element or compound toxic to the test organism was present in the sample from September that was not present in earlier samples or that an essential nutrient other than phosphorus or nitrogen was depleted in Muddy Creek in September 1987. Those reasons are applicable only to the alga used for the AGP test. The test alga may not be native to Muddy Creek; it cannot be assumed that other species of algae would not have grown in the sample collected on September 15 from Muddy Creek.

\section{SEDIMENT DISCHARGE AND RESERVOIR SEDIMENTATION}

For preliminary planning and design of a reservoir, knowledge of the sediment discharge into the reservoir is needed to determine the effect sedimentation has on the long-term water-storage capacity of the reservoir. The sedimentation rate of a proposed reservoir can be estimated if stream discharge, sediment discharge, sediment-particle size, and reservoir-operation plans and size are known. Preliminary estimates of sedimentation rate have been reported for Rock Creek Reservoir (Butler, 1987) and for Wolford Mountain Reservoir (Ruddy, 1987). Additional sediment data were collected from Rock and Muddy Creeks and used to revise the sediment-transport equations and the sedimentation rates reported in Butler (1987) and Ruddy (1987). Methods for computing the transport equations, total and annual sediment discharges, and the sedimentation rates are described in the cited reports.

\section{$\underline{\text { Rock Creek Reservoir }}$}

The suspended-sediment-discharge to stream-discharge relation developed by Butler (1987) for Rock Creek was based on sediment data collected from 1976 to 1985 at the Toponas gage. A single relation was used to compute suspendedsediment discharge in Rock Creek. The suspended-sediment-discharge relation was recomputed by including nine suspended-sediment samples collected in 1986 (table 19) with the data collected from 1976 to 1985 . The original and revised relations are listed in table 20 (first and second equations) and plotted in figure 33. Inclusion of the nine samples collected in 1986 did not substantially change the equation, primarily because of the relatively large sample size. A greater proportion of the samples collected from 1976 to 1984 (Butler, 1987) were collected at lower stream discharge than were the samples collected in 1985 and 1986. A relation was determined using only the suspended-sediment data collected in 1985 and 1986 (third equation, table 20). 
Table 19.--Stream-discharge and sediment data collected during 1986 at gaging station 09060500, Rock Creek near Toponas

[Correction factor is the fraction of the stream discharge actually sampled by the suspended-sediment sampler (see Colby and Hembree, 1955, for discussion); corrected suspended-sediment discharge is $0.0027 \times$ stream discharge $x$ suspended-sediment concentration $x$ correction factor; --, no data]

\begin{tabular}{ccccccc}
\hline $\begin{array}{c}\text { Date } \\
\text { of } \\
\text { sample }\end{array}$ & $\begin{array}{l}\text { Stream } \\
\text { discharge } \\
\text { (cubic } \\
\text { feet per } \\
\text { second) }\end{array}$ & $\begin{array}{c}\text { Suspended- } \\
\text { sediment } \\
\text { concentration } \\
\text { (milligrams } \\
\text { per liter) }\end{array}$ & $\begin{array}{c}\text { Correction } \\
\text { factor }\end{array}$ & $\begin{array}{l}\text { Corrected } \\
\text { suspended- } \\
\text { sediment } \\
\text { discharge } \\
\text { (tons per day) }\end{array}$ & $\begin{array}{c}\text { Bedload } \\
\text { discharge } \\
\text { (tons per } \\
\text { day) }\end{array}$ & $\begin{array}{c}\text { Total- } \\
\text { sediment } \\
\text { discharge } \\
\text { (tons per } \\
\text { day) }\end{array}$ \\
\hline $04-24-86$ & 173 & 38 & 0.88 & 16 & 16 & 32 \\
$04-28-86$ & 104 & 17 & .82 & 3.9 & 4.7 & 8.6 \\
$05-12-86$ & 182 & 15 & .89 & 6.6 & 6.3 & 13 \\
$05-15-86$ & 209 & 16 & .90 & 8.1 & 7.1 & 15 \\
$05-20-86$ & 226 & 17 & .90 & 9.3 & 6.9 & 16 \\
$05-21-86$ & 245 & 16 & .92 & 9.7 & 12 & 22 \\
$05-27-86$ & 262 & 14 & .92 & 9.1 & 15 & 24 \\
$05-29-86$ & 253 & -- & .92 & -9 & 13 & -- \\
$06-09-86$ & 219 & 29 & .68 & 16 & 8.9 & 25 \\
$07-02-86$ & 30 & 9 & .50 & .18 & .67 \\
\hline
\end{tabular}

Table 20.--Regression relations of sediment discharge to stream discharge for gaging station 09060500, Rock Creek near Toponas

[ $\mathrm{n}$ is number of data pairs; $\mathrm{r}^{2}$ is coefficient of determination; se is standard error of estimate, in logarithmic units; $\log$ is base 10 logarithm; Qs is suspended-sediment discharge, in tons per day; $Q$ is stream discharge, in cubic feet per second; and $Q b$ is bedload discharge, in tons per day]

\begin{tabular}{|c|c|c|c|c|}
\hline \multirow{2}{*}{$\begin{array}{l}\text { Dependent variable } \\
\text { and period used }\end{array}$} & \multicolumn{4}{|c|}{$\begin{array}{l}\text { Statistical values for regression of } \\
\text { dependent variable to stream discharge }\end{array}$} \\
\hline & $\mathrm{n}$ & $\mathrm{r}^{2}$ & Regression relation & se \\
\hline $\begin{array}{l}\text { Suspended-sediment } \\
\text { discharge, 1976-85 }\end{array}$ & 72 & 0.84 & $\log (Q s)=-2.56+1.40(\log (Q))$ & 0.37 \\
\hline $\begin{array}{l}\text { Suspended-sediment } \\
\text { discharge, } 1976-86\end{array}$ & 81 & .86 & $\log (Q s)=-2.60+1.45(\log (Q))$ & .36 \\
\hline $\begin{array}{l}\text { Suspended-sediment } \\
\text { discharge, } 1985-86\end{array}$ & 23 & .88 & $\log (Q s)=-3.63+1.93(\log (Q))$ & .31 \\
\hline Bedload discharge, 1985 & 13 & .83 & $\log (Q b)=-5.94+2.85(\log (Q))$ & .56 \\
\hline $\begin{array}{l}\text { Bedload discharge, } \\
\quad 1985-86\end{array}$ & 23 & .80 & $\log (Q b)=-4.72+2.38(\log (Q))$ & .45 \\
\hline
\end{tabular}




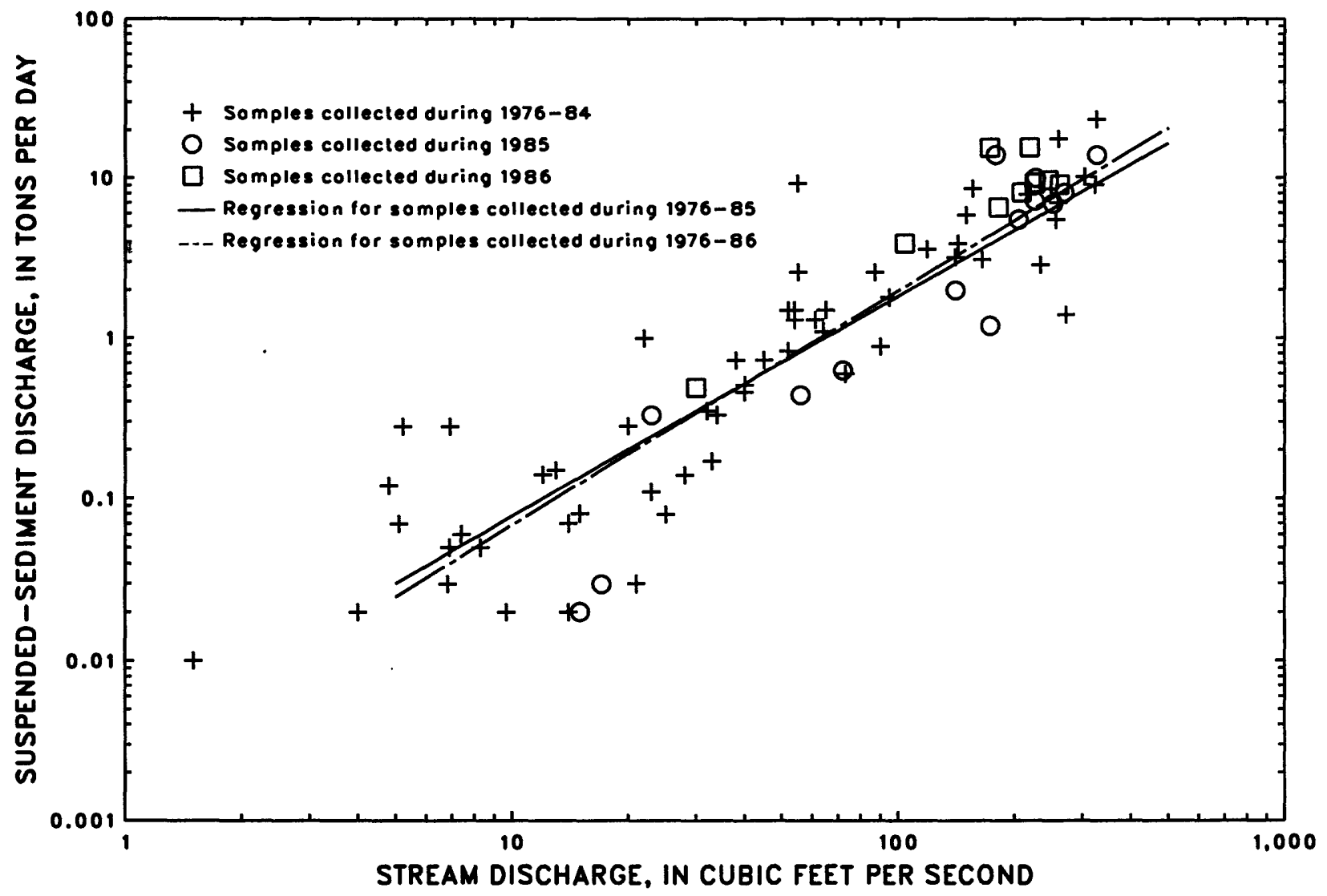

Figure 33.--Relation of suspended-sediment discharge to stream discharge at gaging station 09060500 , Rock Creek near Toponas. 
Ten bedload discharge measurements were made in 1986 (table 19). The relation of bedload discharge to stream discharge based on data for 1985 and 1986 is different than the relation of bedload discharge to stream discharge based only on samples collected in 1985, as listed in table 20 and shown in figure 34. Bedload discharge accounted for about 50 percent of the totalsediment discharge for many of the samples collected during the runoff period in 1986. A similar conclusion was reported by Butler (1987) based on the sediment data collected in 1985 .

The mean annual discharge for suspended and bedload sediment were estimated using the revised regression relations and the stream discharge record (water years 1953-80) for the Toponas gage. The mean annual sediment discharges were adjusted to correct for statistical bias inherent in log-log regression relations (Ferguson, 1986). The mean suspended-sediment discharge was 355 tons/yr using the suspended-sediment relation based on all suspendedsediment samples (samples collected from 1976 through 1986); this compared to 309 tons/yr using the relation based on samples collected from 1976 through 1985 (Butler, 1987) and 351 tons/yr using the relation based on samples collected in 1985 and 1986. The suspended-sediment discharge at the Toponas gage was increased by 10 percent to account for sediment discharge from Horse Creek, which discharges into Rock Creek between the Toponas gage and the damsite. Applying that adjustment to the suspended-sediment discharge of 355 tons/yr resulted in a mean suspended-sediment discharge of 391 tons/yr in Rock Creek at the reservoir site. The revised mean bedload discharge was 408 tons/yr compared to 428 tons/yr reported in Butler (1987). The revised mean totalsediment discharge was 799 tons/yr; the original estimate was 768 tons/yr.

Determination of the sedimentation rate of the proposed reservoir was made using the revised sediment discharge of 799 tons/yr. The volume of sediment deposits after 100 years would be about 46 acre-ft; the original estimate of Butler (1987) was 44 acre-ft. The sedimentation rate was computed using a reservoir trap efficiency of 100 percent. The water-storage capacity of the proposed reservoir $(50,700$ acre-ft) would decrease by less than 1 percent after 100 years using either estimate of sedimentation rate. That conclusion would only be valid if there are no major changes in the Rock Creek basin upstream from the reservoir site that could affect sediment discharge in Rock Creek.

\section{Wolford Mountain Reservoir}

The sediment-discharge relations for Muddy Creek and the sedimentation rate for Wolford Mountain Reservoir reported by Ruddy (1987) were made using sediment data collected in 1985 and stream-discharge data collected in the water years 1983-1985 at the Muddy Creek gage. A second season of suspendedsediment and bedload data were collected during the water year 1986, and suspended-sediment data also were collected during 1987 (table 21). The sediment-discharge relations and sedimentation rate for the proposed reservoir site were revised by including sediment data and the stream-discharge data collected in 1986 and 1987 at the Muddy Creek gage with the sediment and stream discharge data used by Ruddy (1987). 


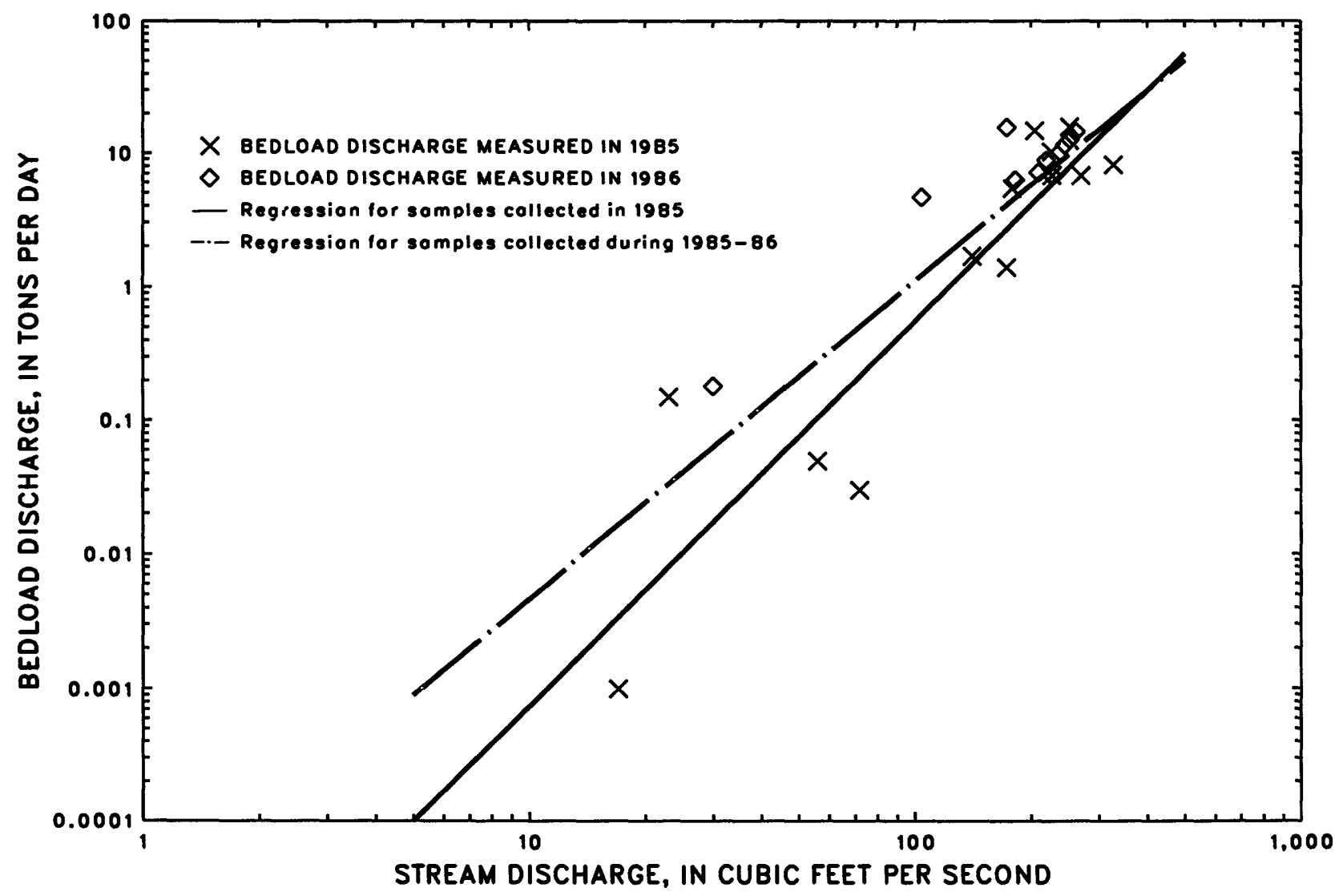

Figure 34.--Relation of bedload discharge to stream discharge at gaging station 09060500, Rock Creek near Toponas. 
Table 21.--stream-discharge and sediment data collected during water years 1986 and 1987 at gaging station 09041500, Muddy Creek at Kremmling

$$
[-- \text {, no data }]
$$

\begin{tabular}{|c|c|c|c|c|c|c|}
\hline $\begin{array}{c}\text { Date } \\
\text { of } \\
\text { sample }\end{array}$ & $\begin{array}{l}\text { Stream } \\
\text { discharge } \\
\text { (cubic } \\
\text { feet per } \\
\text { second) }\end{array}$ & $\begin{array}{l}\text { Suspended- } \\
\text { sediment } \\
\text { concentration } \\
\text { (milligrams } \\
\text { per liter) }\end{array}$ & $\begin{array}{l}\text { Suspended- } \\
\text { sediment } \\
\text { discharge } \\
\text { (tons per } \\
\text { day) }\end{array}$ & $\begin{array}{c}\text { Suspended } \\
\text { sediment } \\
\text { finer than } \\
0.0625 \\
\text { millimeters }\end{array}$ & $\begin{array}{c}\text { Bedload } \\
\text { discharge } \\
\text { (tons per } \\
\text { day) }\end{array}$ & $\begin{array}{l}\text { Total- } \\
\text { sediment } \\
\text { discharge } \\
\text { (tons per } \\
\text { day) }\end{array}$ \\
\hline $12-05-85$ & 29 & 30 & 2.3 & -- & -- & -- \\
\hline $02-26-86$ & 94 & 314 & 80 & 95 & -- & -- \\
\hline $04-23-86$ & 540 & 2,240 & 3,270 & 89 & -- & -- \\
\hline $05-06-86$ & 958 & 525 & 1,360 & 78 & 23 & 1,380 \\
\hline $05-06-86$ & 935 & 506 & 1,280 & 66 & 28 & 1,310 \\
\hline $05-08-86$ & 814 & 760 & 1,670 & 72 & 5.8 & 1,680 \\
\hline $05-12-86$ & 823 & 937 & 2,080 & 62 & 21 & 2,100 \\
\hline $05-14-86$ & 652 & 810 & 1,430 & 63 & 2.5 & 1,430 \\
\hline $05-22-86$ & 724 & 727 & 1,420 & 71 & 19 & 1,440 \\
\hline $06-11-86$ & 367 & 140 & 139 & 86 & 9.9 & 149 \\
\hline $07-16-86$ & 101 & 140 & 38 & -- & 4.6 & 43 \\
\hline $08-27-86$ & 32 & 77 & 6.7 & 99 & -- & -- \\
\hline $04-24-87$ & 359 & 1,690 & 1,640 & 94 & -- & -- \\
\hline $04-27-87$ & 508 & 2,090 & 2,870 & 88 & -- & -- \\
\hline $04-29-87$ & 637 & 2,570 & 4,420 & 87 & -- & -- \\
\hline $05-01-87$ & 557 & 1,150 & 1,730 & 79 & -- & -- \\
\hline $05-05-87$ & 300 & 351 & 284 & 65 & -- & -- \\
\hline $05-08-87$ & 334 & 358 & 323 & 88 & -- & -- \\
\hline $05-14-87$ & 257 & 220 & 153 & 92 & -- & -- \\
\hline $05-21-87$ & 222 & 180 & 108 & 97 & -- & -- \\
\hline $06-04-87$ & 31 & 107 & 9.0 & 69 & -- & -- \\
\hline $07-16-87$ & 44 & 123 & 15 & 77 & -- & -- \\
\hline $08-14-87$ & 19 & 154 & 7.9 & 70 & -- & -- \\
\hline $09-17-87$ & 19 & 154 & 7.9 & 92 & -- & -- \\
\hline
\end{tabular}

Suspended-sediment data were separated into three groups as was done by Ruddy (1987). Two periods were used: March through August and September through February. Ruddy (1987) determined that the best regression relations for the March through August period were obtained if the data were separated into rising- and falling-stream-stage periods relative to the date of the annual peak suspended-sediment discharge. The annual peak suspended-sediment discharge preceded the annual peak stream discharge by 2 days in 1985 (Ruddy, 1987). The revised relations for suspended-sediment discharge are compared in table 22 to the relations developed by Ruddy (1987), and the revised and original relations are plotted in figures 35 through 37 . Most of the 
suspended-sediment samples collected in 1986 and 1987 were collected from March to August during the falling-stage period. The revised relations for the falling-stage period and base-flow period are statistically different than the original relations. The revised relation for the falling-stage period resulted in larger suspended-sediment discharges than the original relation for the falling-stage period. The revised base-flow relation was substantially affected by the sample collected on February 26, 1986 (table 21), during unusual winter conditions of warm weather accompanied by rain. The relations for the base-flow period listed in table 22 were computed using the mean concentration of the samples.

Table 22.--Regression relations of suspended-sediment discharge to stream discharge for gaging station 09041500, Muddy Creek at Kremmling

[ $\mathrm{n}$ is number of data pairs; $\mathrm{r}^{2}$ is coefficient of determination; se is standard error of estimate, in logarithmic units; log is base 10 logarithm; Qs is suspended-sediment discharge, in tons per day; $Q$ is stream discharge, in cubic feet per second]

\begin{tabular}{lllll}
\hline \multirow{2}{*}{ Period used } & \multicolumn{4}{c}{$\begin{array}{c}\text { Statistical values for regression of } \\
\text { dependent variable to stream discharge }\end{array}$} \\
\cline { 2 - 5 } & $\mathrm{n}$ & $\mathrm{r}^{2}$ & Regression relation & se \\
\hline $\begin{array}{l}\text { March through August } \\
\text { rising stage, 1985 }\end{array}$ & 6 & 0.96 & $\log (\mathrm{Qs})=-2.85+2.32(\log (\mathrm{Q}))$ & 0.26 \\
$\begin{array}{l}\text { March through August } \\
\text { falling stage, 1985 }\end{array}$ & 7 & .97 & $\log (\mathrm{Qs})=-2.25+1.77(\log (\mathrm{Q}))$ & .15 \\
$\begin{array}{l}\text { September through February } \\
\text { base flow, 1985 }\end{array}$ & 3 & 1.00 & $\log (\mathrm{Qs})=-0.82+\log (\mathrm{Q})$ & .00 \\
$\begin{array}{l}\text { March through August } \\
\text { rising stage, 1985-87 }\end{array}$ & 10 & .97 & $\log (\mathrm{Qs})=-2.88+2.33(\log (\mathrm{Q}))$ & .19 \\
$\begin{array}{l}\text { March through August } \\
\text { falling stage, 1985-87 }\end{array}$ & 24 & .93 & $\log (\mathrm{Qs})=-1.38+1.52(\log (\mathrm{Q}))$ & .22 \\
$\begin{array}{l}\text { September through February } \\
\text { base flow, 1985-87 }\end{array}$ & 6 & 1.00 & $\log (\mathrm{Qs})=-0.52+\log (\mathrm{Q})$ & .00 \\
\hline
\end{tabular}

The bedload-discharge relations are listed in table 23 and are plotted in figure 38. Additional bedload data did not result in improvement of the regression relation; the coefficient of determination $\left(r^{2}\right)$ decreased, and the error estimate increased (table 23). The bedload discharges measured in 1986 had a poor correlation to stream discharge (coefficient of determination was 0.12); therefore, inclusion of those samples with the data for 1985 resulted in a poorer relation of bedload discharge to stream discharge compared to the relation based on data for 1985. However, comparison of the bedload discharges to total-sediment discharges for the samples collected in 1986 did 


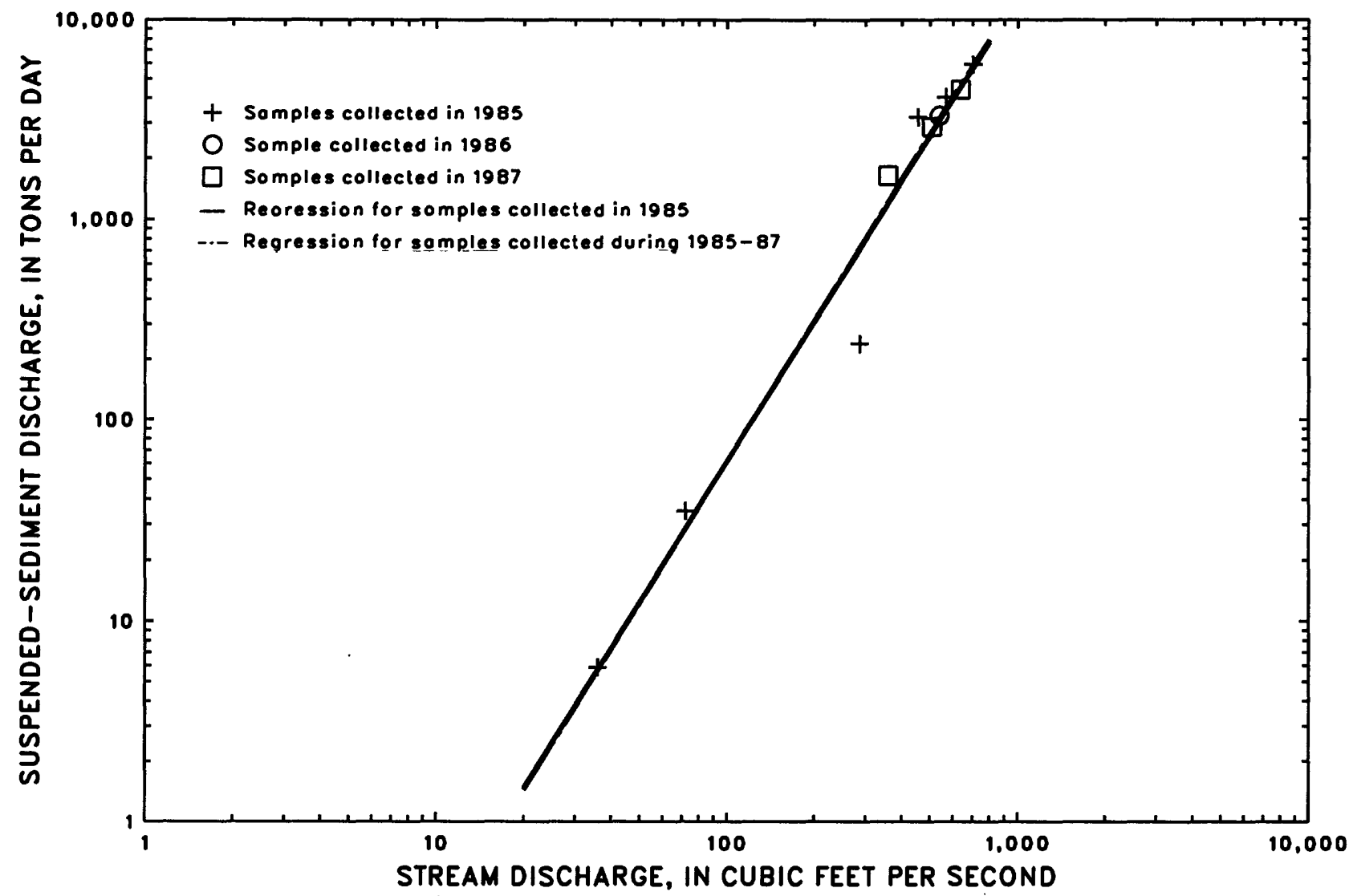

Figure 35.--Relation of suspended-sediment discharge to stream discharge, March through August, rising stage, at gaging station 09041500, Muddy Creek at Kremmling. 


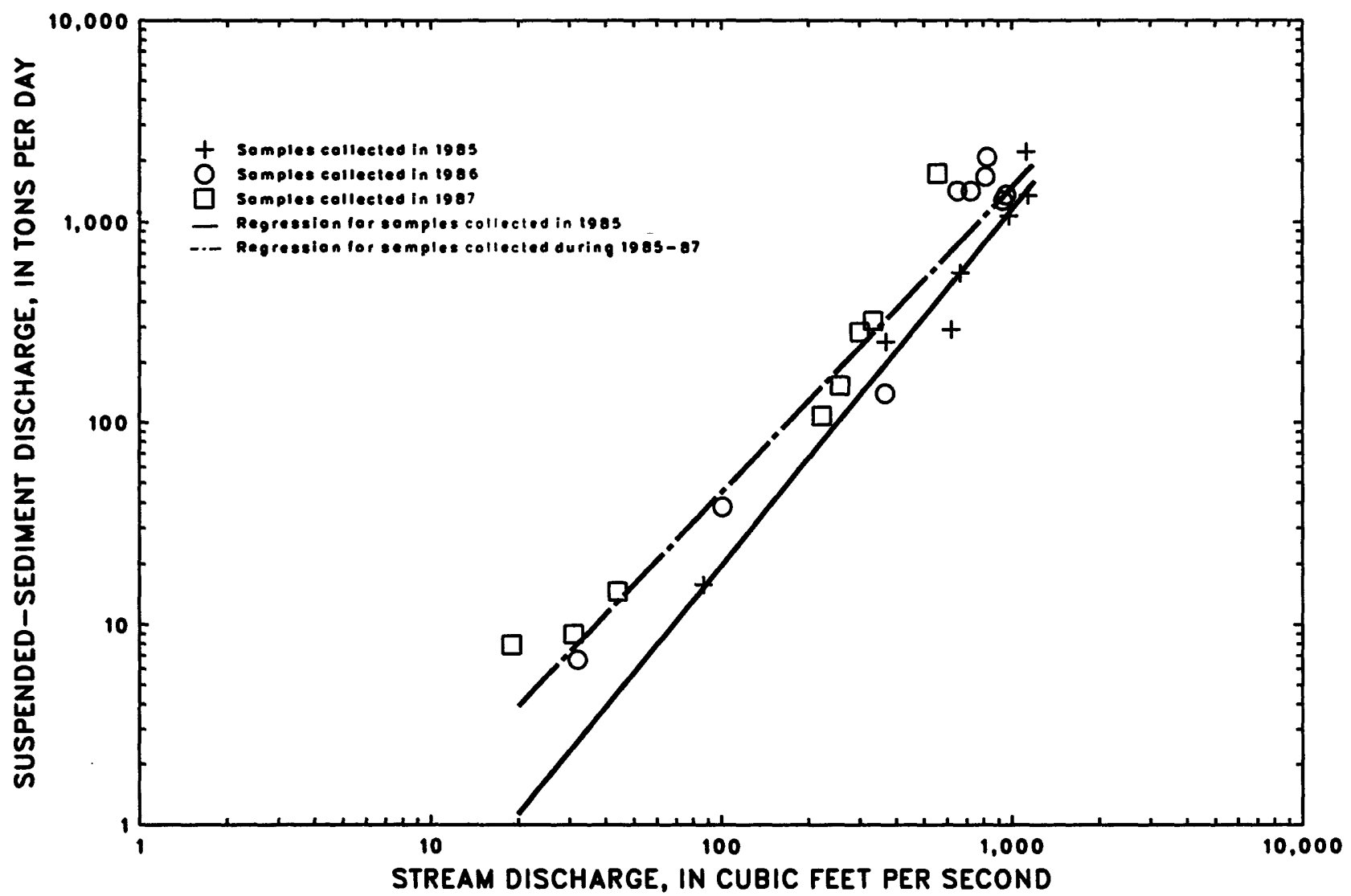

Figure 36.--Relation of suspended-sediment discharge to stream discharge, March through August, falling stage, at gaging station 09041500, Muddy Creek at Kremmling. 


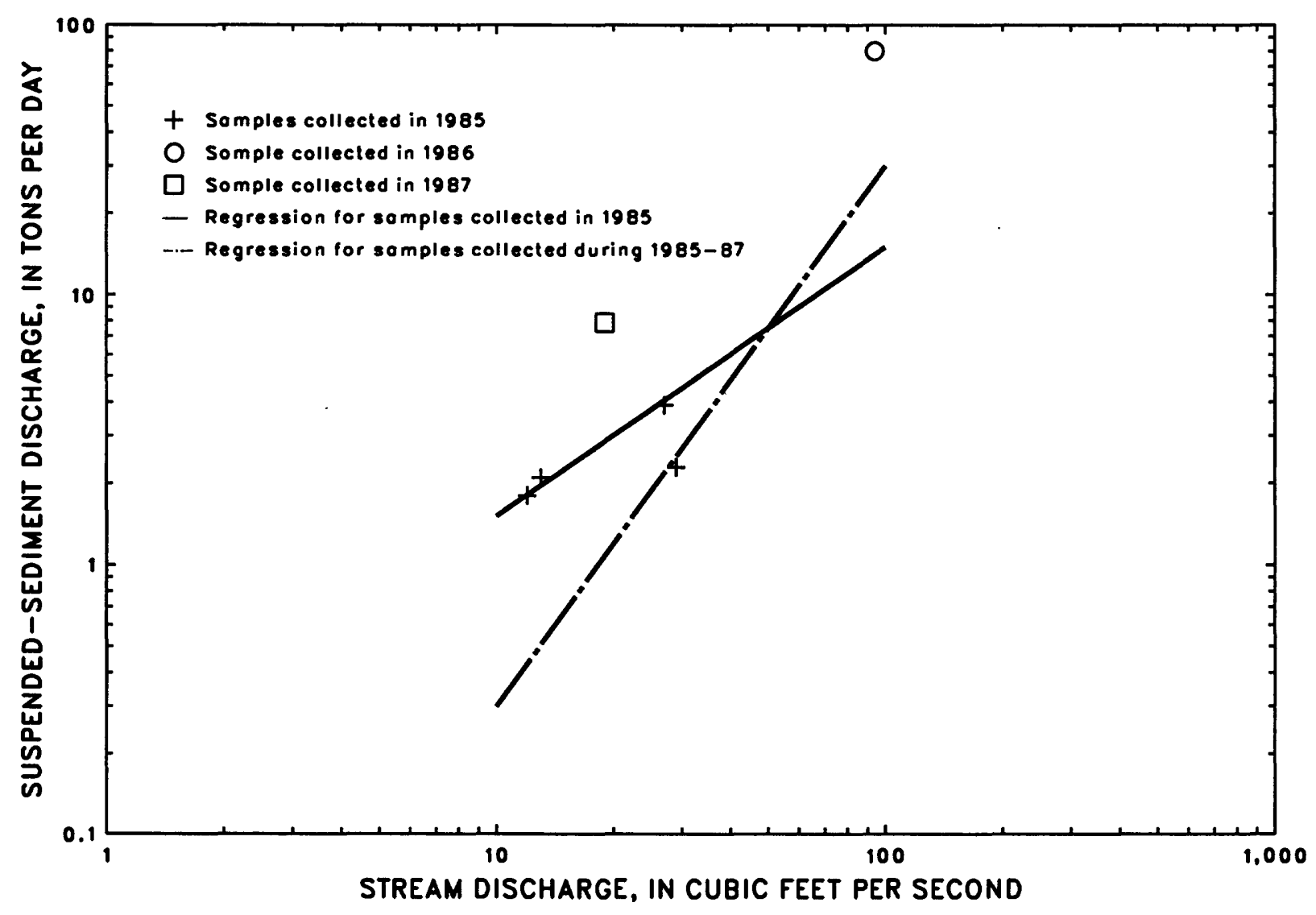

Figure 37.--Relation of suspended-sediment discharge to stream discharge, September through February, at gaging station 09041500, Muddy Creek at Kremmling. 
confirm Ruddy's (1987) conclusion that bedload discharge accounts for less than 3 percent of the total-sediment discharge in Muddy Creek. Therefore, errors in estimating bedload discharge would have negligible effect on the estimate of sedimentation in the proposed reservoir.

Table 23.--Regression relation of bedload discharge to stream discharge for gaging station 09041500, Muddy Creek at Kremmling

[ $\mathrm{n}$ is number of data pairs; $\mathrm{r}^{2}$ is coefficient of determination; se is standard error of estimate, in logarithmic units; $\log$ is base 10 logarithm; Qb is bedload discharge, in tons per day; $Q$ is stream discharge, in cubic feet per second]

\begin{tabular}{cccccc}
\hline \multirow{2}{*}{$\begin{array}{c}\text { Period used } \\
\end{array}$} & \multicolumn{4}{c}{$\begin{array}{c}\text { Statistical values for regression of } \\
\text { dependent variable to stream discharge }\end{array}$} \\
\cline { 2 - 5 } & $\mathrm{n}$ & $\mathrm{r}^{2}$ & Regression relation & se \\
\hline 1985 & 9 & 0.81 & $\log (\mathrm{Qb})=-4.40+1.97(\log (\mathrm{Q}))$ & 0.33 \\
$1985-86$ & 17 & .54 & $\log (\mathrm{Qb})=-2.68+1.35(\log (\mathrm{Q}))$ & .40 \\
\hline
\end{tabular}

Estimates of the mean annual discharge of suspended and bedload sediment were made using the revised regression relations and the stream-discharge data for water years 1983-87. The revised mean sediment discharges (corrected for the statistical bias previously described) were 90,960 tons/yr of suspended sediment and 1,950 tons/yr of bedload sediment. The mean total-sediment discharge is 92,910 tons/yr, compared to 83,000 tons/yr reported by Ruddy (1987).

The sedimentation rate for the proposed Wolford Mountain Reservoir was estimated for 100 years using the revised mean annual total-sediment discharge. A minor change was made to the particle-size data used to compute the specific weight of sediment deposits (method described by Strand and Pemberton, 1982). A slightly greater percentage of sand was used in the computation, which increased the specific weight of sediment deposits from $65.4 \mathrm{lb} / \mathrm{ft}^{2}$ (Ruddy, 1987) to $68.8 \mathrm{lb} / \mathrm{ft}^{2}$. The estimated volume of sediment deposits after 100 years was 6,200 acre-ft, compared to 5,830 acre-ft of deposits after 100 years reported in Ruddy (1987). Those estimates assume 100-percent trap efficiency of the reservoir. The water-storage capacity after 100 years of sediment deposits $(6,200$ acre-ft), using the revised sedimentation rate for a reservoir capacity initially of 60,000 acre-ft, would be 53,800 acre-ft, or a decrease of about 11 percent. Ruddy (1987) reported a decrease of storage capacity of 10 percent. Thus, inclusion of additional sediment and discharge data for Muddy Creek did not substantially change the estimated sedimentation rate of Wolford Mountain Reservoir. 


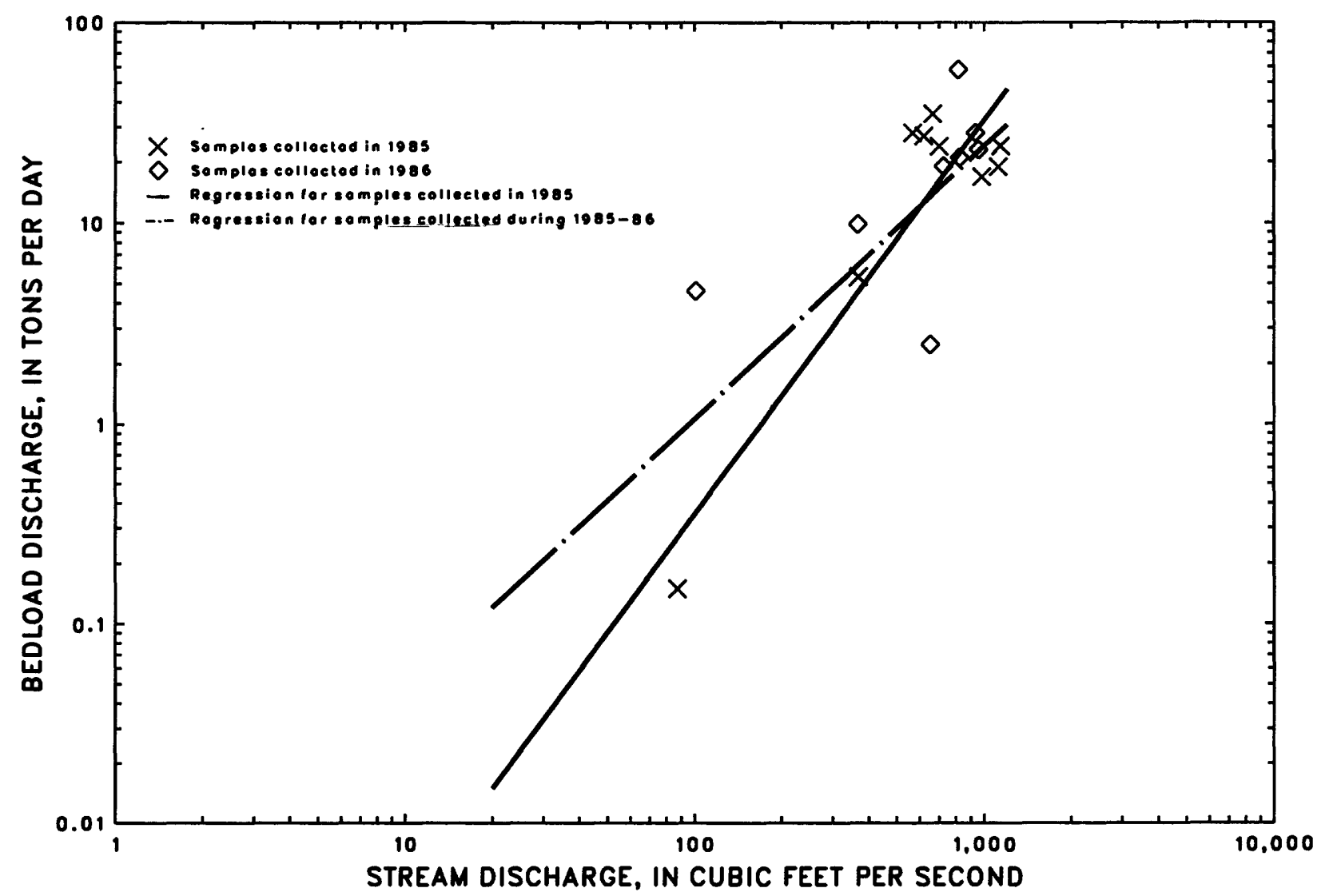

Figure 38.--Relation of bedload discharge to stream discharge at gaging station 09041500, Muddy Creek at Kremmling. 


\section{DOWNSTREAM CHANNEL DEGRADATION}

Construction of a reservoir on a stream can change the downstream water discharge, sediment discharge, channel geometry, and riparian habitat. Reservoirs usually trap much of the sediment load of the stream, which results in clear-water releases to the downstream channel. The clear water has a greater capacity to transport sediment than the previous natural flow and therefore, it may erode the stream bank and streambed. Williams and Wolman (1984) describe changes in channel geometry downstream from 21 dams in the Western and Central United States and report that channel degradation (a decrease in streambed elevation) was common immediately downstream from the dams. Williams and Wolman (1984) developed methods to estimate potential changes in streambed elevation and channel width. These are empirical methods that require data that can be obtained only from stream channels downstream from existing dams, and they cannot be used for predictive purposes for a proposed reservoir site.

Methods have been developed for estimating channel degradation using sediment-transport theory (Simons and Senturk, 1977; Vanoni, 1975). Mathematical computer models have been used for predicting channel degradation; however, such models may be limited to specific types of streams (Strand and Pemberton, 1982). The U.S. Bureau of Reclamation (Strand and Pemberton, 1982) has developed simpler methods for determining potential channel degradation at planned reservoir sites. These methods are useful for planning purposes because the data required can be acquired prior to dam construction. Two methods are described by Strand and Pemberton (1982) for estimating channel degradation:

1. Stable slope method.--This method assumes that insufficient coarse material is available downstream from the damsite to develop an armoring layer. Another assumption is that nonerodible layers are not present below the streambed to inhibit vertical degradation. The method computes a channel slope at which the stream could no longer transport the bed material present in the stream. The depth of channel degradation is determined from the difference between streambed elevations of the existing channel-slope profile and the stable channel-slope profile. The existing stream channels at the proposed damsites do not satisfy the assumptions for using this method.

2. Armoring method.--This method assumes that sufficient quantities of coarse bed material that would not be transported by the expected postconstruction stream discharges are available downstream from the damsite. As shown in figure 39, an armoring layer would be formed on the streambed as fine material is winnowed from the streambed and transported downstream by the water released from the reservoir. Vertical degradation would be slowed as the armoring layer developed until a layer of sufficient thickness (YA in fig. 39) was formed that inhibited further channel degradation. The particle size required for armoring (DC in fig. 39) is computed from hydraulic data and related to the existing bed-material size to compute degradation depth. The particle size of the armor material is computed using five empirical relations that predict the critical-particle size of nontransportable bed material. The five estimates of critical-particle size are averaged to estimate the diameter of the armoring material (DC). The layer thickness required to form an 


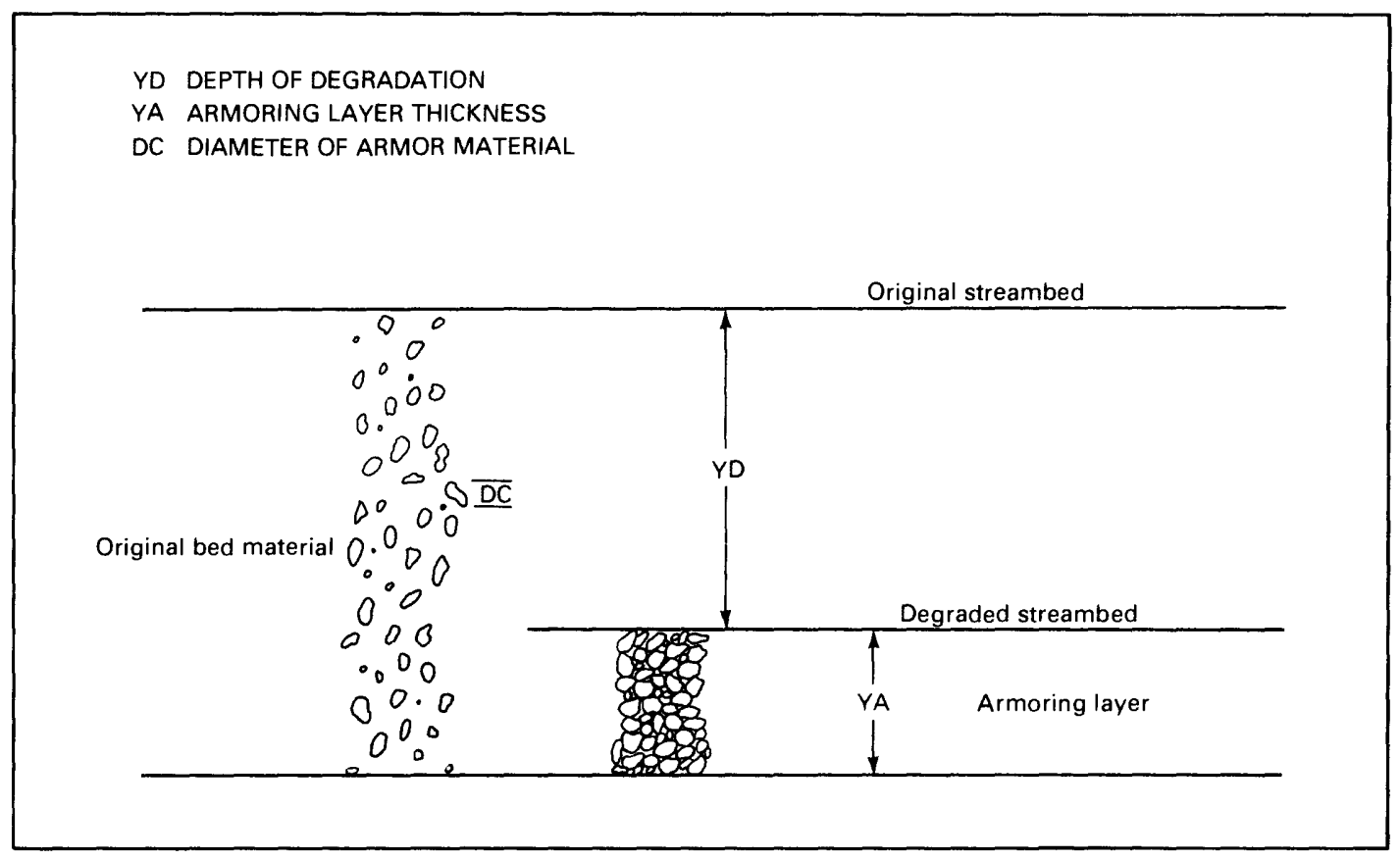

Figure 39.--Schematic of the armoring method for estimating channel degradation (adapted from Strand and Pemberton, 1982). 
armoring layer (YA) is equal to three times DC. The depth of degradation (YD in fig. 39) is then computed from the relation $\mathrm{YD}=\mathrm{YA}(1 / \mathrm{P}-1)$, where $\mathrm{P}$ is the decimal percentage of the original bed material larger than $D C$.

The armoring method was selected for estimating channel degradation downstream from the damsites of the proposed Rock Creek and Wolford Mountain Reservoirs. The bed-material sizes at both sites were assumed to be large enough to form armoring layers. Data needed to use the armoring method are: (1) Bed-material size in the selected reach; (2) the dominant discharge (Strand and Pemberton, 1982); and, (3) average hydraulic properties for the dominant discharge. For this study, the dominant discharge was assumed equal to bankfull discharge in the selected reach.

Longitudinal stream profiles and three cross sections were surveyed for a selected reach downstream from each proposed damsite. The bankfull stage was estimated from floodplain morphology and vegetation at each cross section. The bankfull discharge and related hydraulic data were computed for the bankfull stage at each cross section. Channel conveyance and stream discharge were computed from the Manning equation (Chow, 1959). The Manning $n$ coefficients for the bankfull stage were estimated using methods described by Jarrett (1985). Water-surface slopes were determined for the estimated bankfull stage from the longitudinal survey made at each study reach. Average values of the hydraulic data were used for the computations of criticalparticle size of the armor material.

The conclusions regarding channel degradation presented in the following sections are limited to short stream sections downstream from each proposed damsite. The results presented only apply to the reaches studied. A more comprehensive assessment of channel morphology is presented in the Environmental Impact Statement (U.S. Forest Service, 1988). For that study, potential morphological changes were assessed for Rock and Muddy Creeks from the damsites to the confluence of the streams with the Colorado River.

\section{Rock Creek Damsite}

A 500-ft reach of Rock Creek immediately downstream from the proposed damsite was studied to determine potential channel degradation. Rock Creek flows through a narrow valley downstream from the damsite. The valley bottom has dense growth of willows and brush that grade into grass and sagebrush above the flood plain. 0ld debris flows from valley sides and gullies are evident in the study reach. A longitudinal profile of the reach and three cross sections were surveyed. The approximate locations of the cross sections relative to the damsite are shown in figure 40 . Pebble counts were made at cross sections 1 and 2 to determine particle size of the bed material

(fig. 41).

The average bankfull discharge and related hydraulic properties are summarized in table 24 . The bed material in the Rock Creek streambed in the study reach was quite uniform. Pebble counts were not made at cross section 3 because the bed-material size was similar to that at cross section 2. The D50 and D90 values in table 24 for Rock Creek are composites of the particle sizes at cross sections 1 and 2 . The computed critical-particle size of the armor 


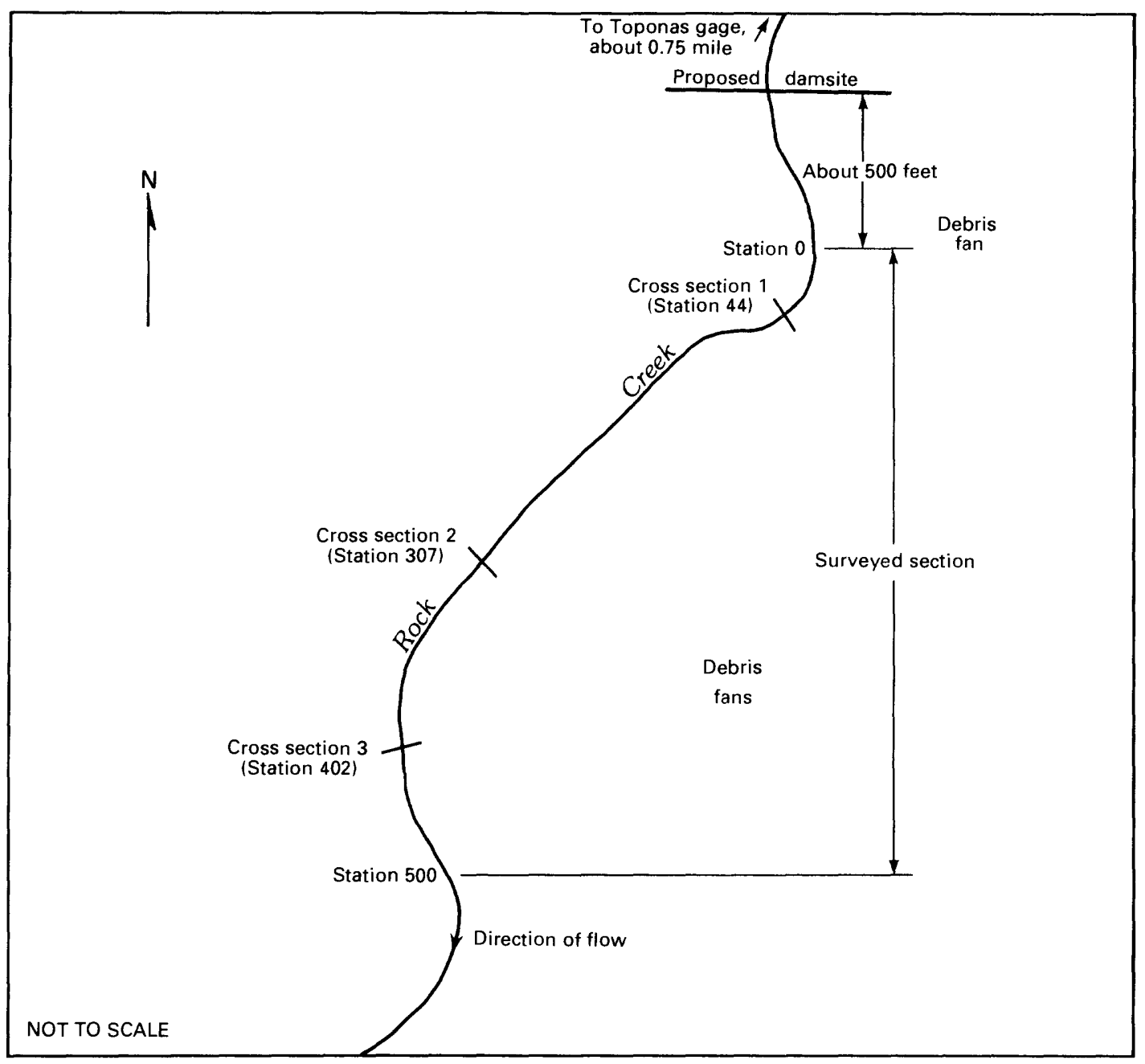

Figure 40.--Approximate location of surveyed section and channel cross sections downstream from the Rock Creek damsite. 


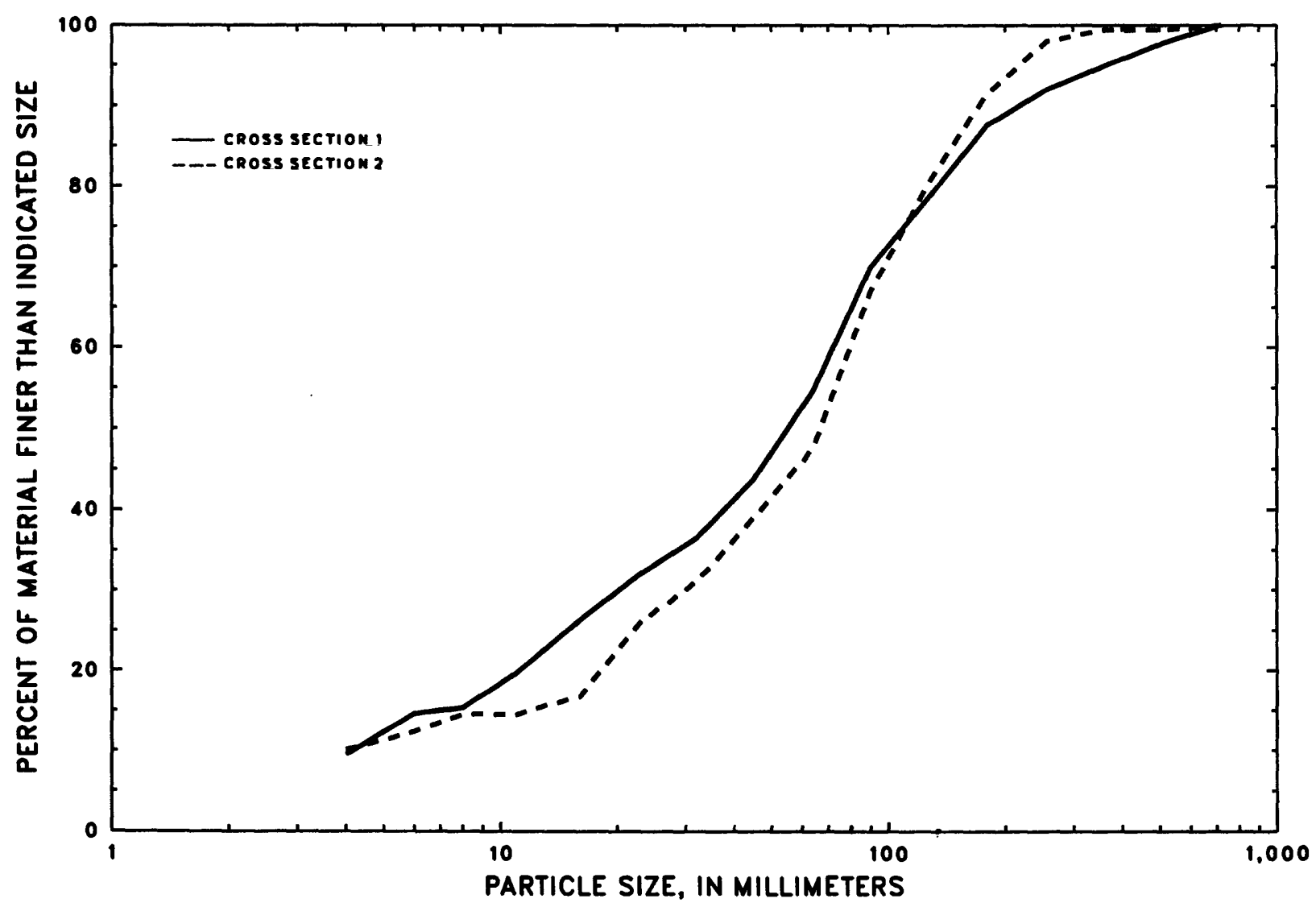

Figure 41.--Particle-size distribution of bed material from pebble-count data collected downstream from the Rock Creek damsite. 
material is $35 \mathrm{~mm}$, which results in an armoring layer thickness of $0.34 \mathrm{ft}$. The depth of degradation for the study reach is $0.19 \mathrm{ft}$. The estimated degradation depth at the Rock Creek damsite is not large relative to the observed degradation depths downstream from many of the dams described by Williams and Wolman (1984). This conclusion is reasonable based on the small sediment discharge in Rock Creek and the coarse composition of the streambed in the Rock Creek channel. The estimated depth of degradation is applicable only to the reach surveyed. Williams and Wolman (1984) reported considerable variability in streambed-elevation changes with distance downstream from some dams, and there were streams where the maximum degradation was not at the nearest cross section downstream from the dam. For the Rock Creek damsite, degradation is not expected to increase downstream from the surveyed reach because the stream begins to flow into a deep, narrow canyon that is incised in granite.

Table 24.--Estimated bankfull discharge and related hydraulic properties and bed-material size for a reach downstream from the damsites of the proposed Rock Creek and Wolford Mountain Reservoirs

[Hydraulic data represent average values of three measured cross sections at each site; D50 is median particle size of bed material; D90 is the size at which 90 percent of the bed material is smaller]

\begin{tabular}{|c|c|c|c|c|c|c|c|c|}
\hline $\begin{array}{c}\text { Reservoir } \\
\text { site }\end{array}$ & $\begin{array}{l}\text { Bankfull } \\
\text { discharge } \\
\text { (cubic } \\
\text { feet per } \\
\text { second) }\end{array}$ & $\begin{array}{c}\text { Area } \\
\text { (square } \\
\text { feet) }\end{array}$ & $\begin{array}{l}\text { Velocity } \\
\text { (feet } \\
\text { per } \\
\text { second) }\end{array}$ & $\begin{array}{l}\text { Hydraulic } \\
\text { radius } \\
\text { (feet) }\end{array}$ & $\begin{array}{l}\text { Water } \\
\text { surface } \\
\text { slope }\end{array}$ & $\begin{array}{c}\text { Manning } s \\
n\end{array}$ & $\frac{\mathrm{D} 50}{\text { (milli }}$ & $\frac{\mathrm{D} 90}{\text { meters })}$ \\
\hline $\begin{array}{l}\text { Rock } \\
\quad \text { Creek }\end{array}$ & 179 & 50.0 & 3.58 & 1.61 & 0.0084 & 0.053 & 62 & 186 \\
\hline $\begin{array}{l}\text { Wolford } \\
\text { Mountain }\end{array}$ & 687 & 147.6 & 4.65 & 3.01 & .0032 & .041 & 33 & 164 \\
\hline
\end{tabular}

The magnitude of error associated with the estimated degradation depth is not known, but can be described qualitatively. Error in sampling the bedmaterial-size distribution affects the estimated degradation depth. Use of a coarser bed-material-size distribution would decrease the estimated degradation depth, because less bed material would have to be removed to obtain the armoring-layer thickness. Use of a finer bed-material-size distribution would increase the estimated degradation depth, because more material would have to be removed to obtain the armoring-layer thickness. For example, changing the particle-size distribution by 10 percent resulted in less than $0.1 \mathrm{ft}$ change in degradation depth. Error in the estimate of dominant discharge affects various hydraulic parameters used to compute the criticalparticle size of the armor material (DC) and the armoring-layer thickness (YA). For example, if the dominant discharge of the postdam releases was larger than the dominant discharge listed in table 24, the particle size of bed material required to form an armoring layer and the degradation depth in 
the channel were underestimated. Increasing the critical-particle size of the armor material by 50 percent from $35 \mathrm{~mm}$ to $52.5 \mathrm{~mm}$ (which increases the armoring layer-thickness from $0.34 \mathrm{ft}$ to $0.52 \mathrm{ft}$ ) increased the degradation depth to $0.29 \mathrm{ft}$, compared to the original estimate of $0.19 \mathrm{ft}$. Although this is a 53-percent increase in degradation depth, in absolute terms the difference is small. If the dominant discharge of the dam releases were smaller than the estimated dominant discharge listed in table 24 (which is more likely to occur), then the critical-particle size would be smaller and the degradation depth would be less than $0.19 \mathrm{ft}$.

Quantitative changes in channel width for Rock Creek cannot be determined using the armoring method. The armoring method in Strand and Pemberton (1982) does not address lateral degradation. If streambanks are erodable, channel widening may be more likely to occur where channel degradation is small (Williams and Wolman, 1984). Channel widening in Rock Creek would depend on erodibility of the bank material and magnitude and frequency of the releases from the reservoir. The alluvial deposits in the valley downstream from the damsite are quite limited, and channel widening may be restricted by bedrock. Dense vegetation along streambanks tends to inhibit lateral degradation by increasing the stability of banks.

\section{Wolford Mountain Damsite}

A 700-ft reach of Muddy Creek about $0.2 \mathrm{mi}$ downstream from the proposed damsite was studied to determine potential channel degradation. This reach of Muddy Creek flows through a fairly narrow canyon that is incised into shale outcrops. The canyon is about $300 \mathrm{ft}$ wide at the damsite (U.S. Forest Service, 1988). The flood plain alluvium consists of clay, sand, and gravel. The stream at the damsite is at the western base of Wolford Mountain. Boulders occur from debris flow and slides from Wolford Mountain in this reach. A longitudinal profile and three cross sections were surveyed; the approximate locations of cross sections relative to the damsite are shown in figure 42. Particle-size data of the bed material were collected at cross sections 1 and 2 and at a point bar downstream from cross section 3 .

The average-bankfull discharge and related hydraulic properties are listed in table 24. The bed-material-size data from pebble counts are shown in figure 43. Two bed-material samples were collected for sieve analysis. One sample for sieve analysis was collected from a point bar near cross section 1, and the second sample was collected at cross section 2. Results of the sieve analyses are shown in figure 44. The particle-size data listed in table 24 is the composite of the three pebble counts. The critical-particle size is $36 \mathrm{~mm}$, and the resulting armoring-layer thickness is $0.35 \mathrm{ft}$. The estimated depth of degradation in the study reach is $0.38 \mathrm{ft}$. The estimated degradation depth was computed using the average bed-material size of all three pebble counts. As evident in figure 43, cross section 1 has coarser bed material than cross sections 2 and 3 . Cross section 1 is located near a debris fan composed of boulders that originates on the west side of Wolford Mountain, and the coarse bed material is confined to a riffle section about $100 \mathrm{ft}$ long. Although the bed material in this reach is not typical of bed material in the channel downstream, this section could act as a local control that inhibits channel degradation. Thus, it may be possible to have greater 


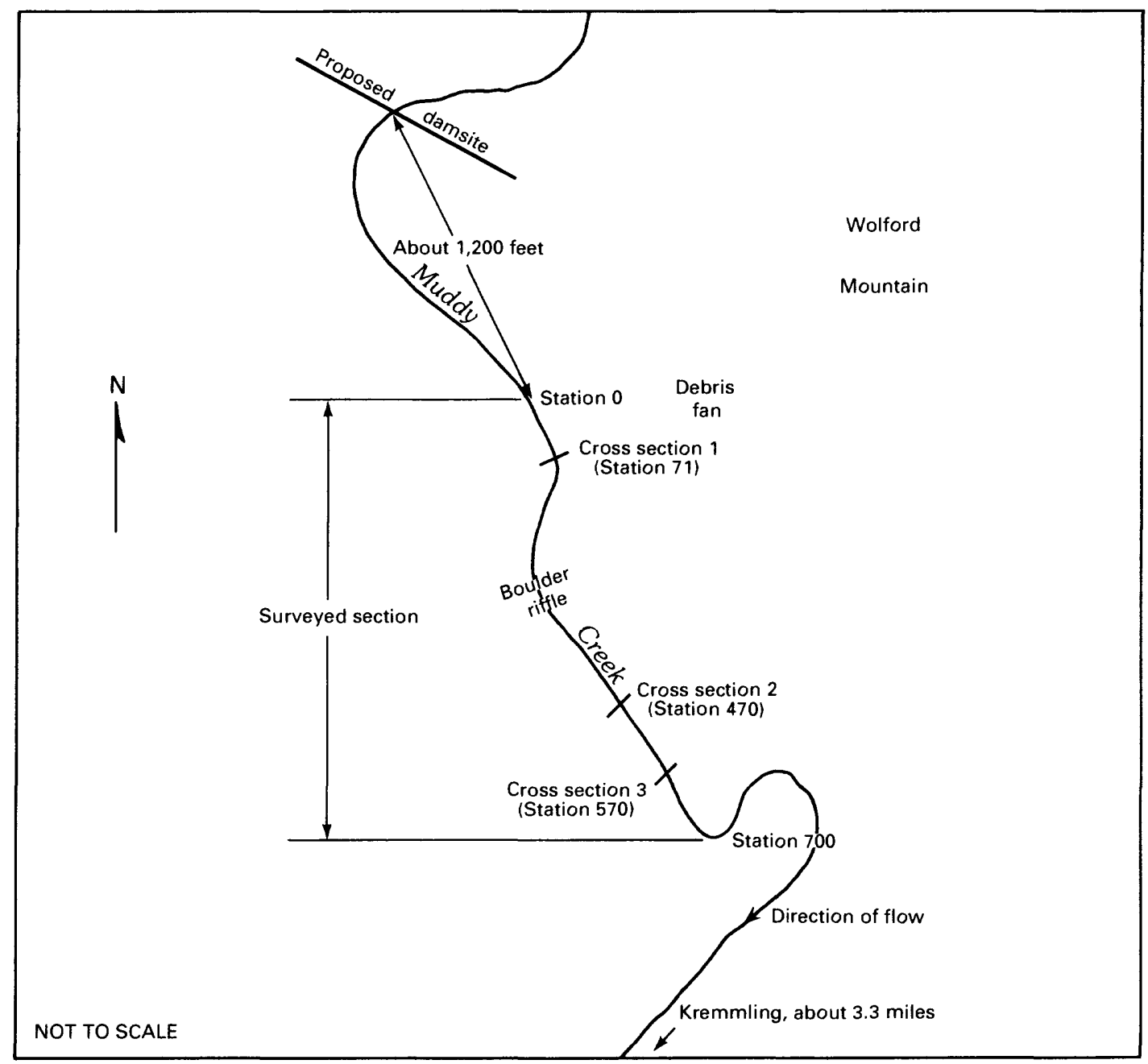

Figure 42.--Approximate location of surveyed section and channel cross sections downstream from the Wolford Mountain damsite. 


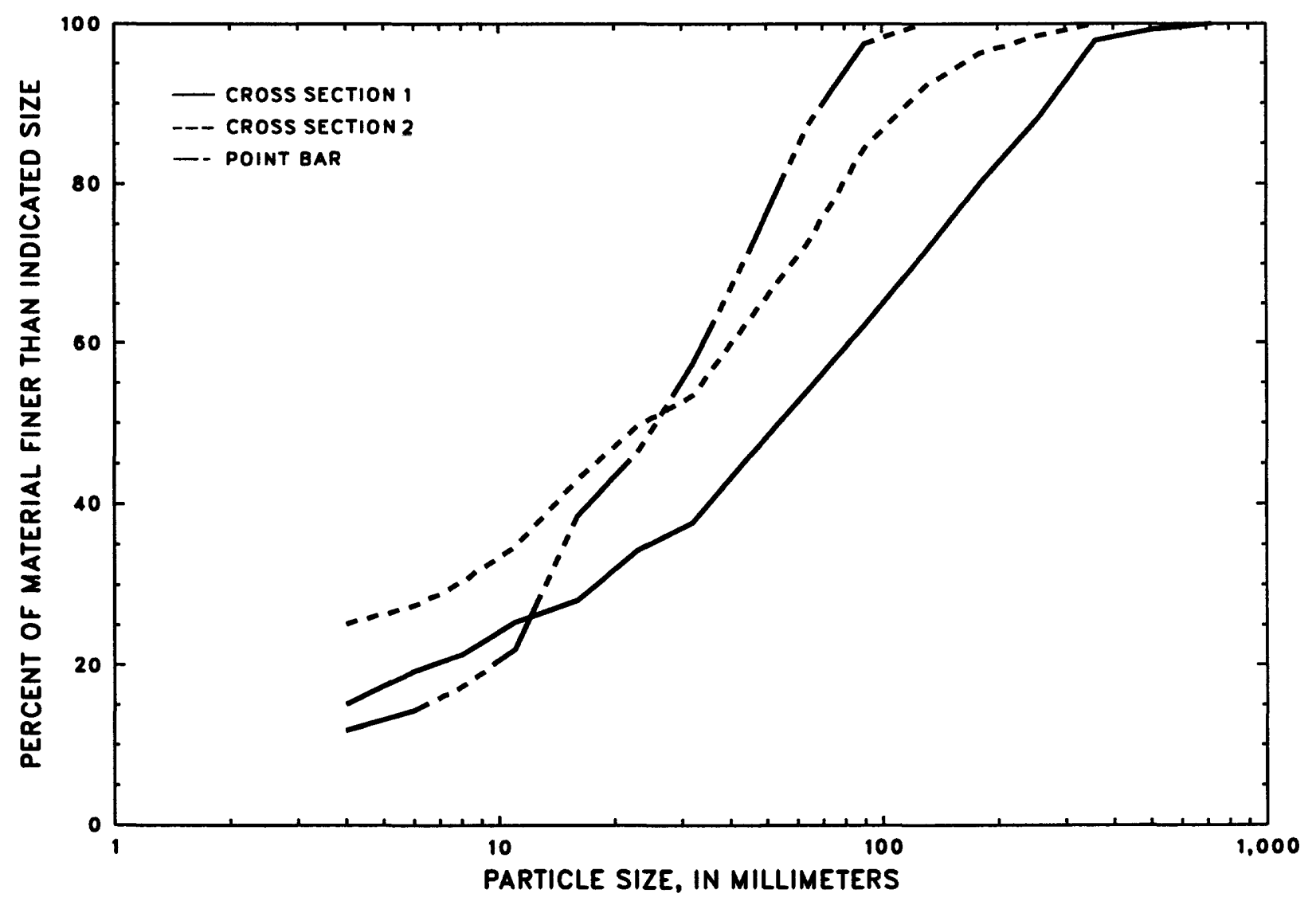

Figure 43.--Particle-size distribution of bed material from pebble-count data collected downstream from the Wolford Mountain damsite. 


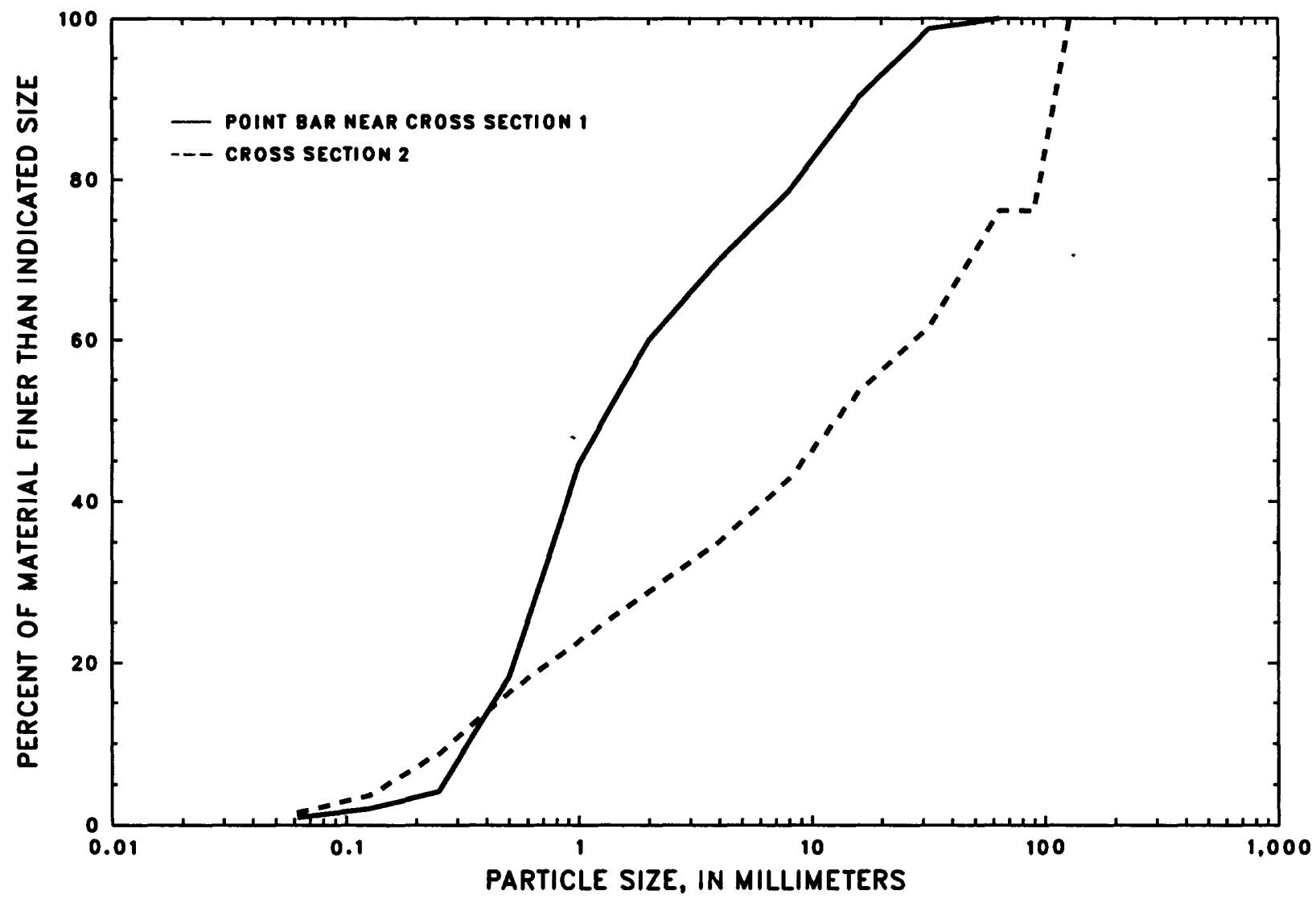

Figure 44.--Particle-size distribution of bed material from sieve-analysis data collected downstream from the Wolford Mountain damsite. 
channel degradation downstream from the surveyed reach because of decreasing bed-material size in Muddy Creek as it flows away from Wolford Mountain and the source of the coarse material. If the pebble-count data for cross section 2 and the point bar downstream from cross section 3 are used, the criticalparticle size of the armor material does not change substantially because it primarily is a function of hydraulic properties such as depth, velocity, and slope. As previously stated, the degradation depth will vary according to the bed-material-size distribution that is used. The estimated degradation depth is $0.51 \mathrm{ft}$, using only the bed-material-size distribution for cross section 2 and the point bar. By comparison, the degradation depth is $0.24 \mathrm{ft}$, using the bed-material-size distribution from cross section 1 .

An underestimate or overestimate of the dominant discharge affects the estimated critical-particle size and, hence, the armoring-layer thickness. It is not likely that dominant discharge in the postconstruction dam releases would be substantially larger than the estimated bankfull discharge of $687 \mathrm{ft}^{3} / \mathrm{s}$ because reservoirs usually decrease annual peak discharges in streams (Williams and Wolman, 1984). If the dominant discharge of the reservoir releases was smaller than the dominant discharge estimated by the existing bankfull discharge, then the critical-particle size of armor material would be less than $36 \mathrm{~mm}$. Estimated degradation depths are decreased when smaller particle-sizes of the armor material are assumed. A critical-particle size of $30 \mathrm{~mm}$ results in a degradation depth of $0.27 \mathrm{ft}$; a critical-particle size of $24 \mathrm{~mm}$ results in a degradation depth of $0.19 \mathrm{ft}$. These estimates use the composite bed-material-size distribution of all three pebble counts.

Channel aggradation could occur if sufficient quantities of fine sediment discharge into Muddy Creek downstream from the damsite. Sediment discharge into Muddy Creek from tributaries such as Cow Gulch and Horse Gulch could cause deposition of sediment in the stream channel if streamflow releases from the reservoir were not large enough to remove these deposits. The Draft Environmental Impact Statement for Muddy Creek (U.S. Forest Service, 1988) assessed the potential for channel aggradation downstream from Wolford Mountain Reservoir. It was concluded that postreservoir streamflows in Muddy Creek would be large enough to remove all sediment supplied by tributaries downstream from the damsite, and channel aggradation would not be likely to occur.

As previously stated, methods were not available to predict lateral erosion of a stream channel for a proposed damsite. Muddy Creek is a meandering channel downstream from the damsite to its confluence with the Colorado River. Cutoff oxbows in this reach are evidence that the streambanks are erodible. Clear-water releases and erodible banks may cause changes in channel morphology in Muddy Creek downstream to the confluence. Alluvium is more extensive downstream from the Muddy Creek damsite than downstream from the Rock Creek damsite, and changes in channel morphology seem more likely to occur in Muddy Creek than in Rock Creek. Changes in channel morphology, such as bank erosion and streambed degradation, can occur within 1 or 2 years after dam closure in semiarid regions (Williams and Wolman, 1984). Thus, if changes in channel morphology did occur in Muddy Creek, such changes might become evident within a short time after dam closure. Another common effect of dams on streams in semiarid areas that are reported by Williams and Wolman (1984) are changes in riparian habitat, especially the pronounced increase of vegetation where channels have narrowed. 


\section{SUMMARY}

Temperature distribution and selected water-quality variables were evaluated for the proposed Rock Creek and Wolford Mountain Reservoirs near Kremmling, north-central Colorado. A one-dimensional temperature and waterquality model was used to simulate temperature and specific-conductance distributions in the reservoirs and in the reservoir outflows. Empirical models were used to estimate total-phosphorus, total-nitrogen, and chorophyl1-a concentrations. An empirical method to estimate dissolved-oxygen depletion in the hypolimnion was not considered suitable for simulation purposes for the proposed reservoirs. All models used for simulation were calibrated or tested using data collected from Williams Fork and Green Mountain Reservoirs. Totalsediment discharge and reservoir sedimentation rates were computed and compared to previously published results. An estimate of potential channel degradation was made for a short reach downstream from each proposed damsite.

The temperature model had errors of about $3{ }^{\circ} \mathrm{C}$ or less for temperature profiles and outflow temperatures based on calibration results. The largest and most consistent errors of the model were for layers near the reservoir bottom. The model was sensitive to volume and timing of inflow stream discharge and to volume and timing of reservoir releases. Temperature of the proposed reservoirs was simulated for May through October using stream discharge and reservoir operations for greater than normal, less than normal, and normal runoff years. Temperature simulations indicate Rock Creek Reservoir would have maximum surface temperatures of about $17{ }^{\circ} \mathrm{C}$ in midsummer, and thermal stratification would occur in most years. Simulated outflow temperatures from Rock Creek Reservoir were 5 to $8{ }^{\circ} \mathrm{C}$ for normal and greater than normal runoff years. Simulated outflow temperatures were cooler than stream temperatures in Rock Creek in midsummer. Outflow temperature was 15 to $16{ }^{\circ} \mathrm{C}$ at the end of August for the less than normal runoff simulation (1977). The warmer outflow temperature for 1977 resulted from reservoir drawdown, which caused warming of the outlet withdrawal layers in the reservoir. In addition to simulating hydrologic conditions, three reservoir outlet elevations $(7,410$ $\mathrm{ft}, 7,420 \mathrm{ft}$, and 7,440 ft) also were included in temperature simulations for Wolford Mountain Reservoir. Maximum surface temperatures of $19{ }^{\circ} \mathrm{C}$ may be expected at Wolford Mountain Reservoir. Thermal stratification could be expected in most years in Wolford Mountain Reservoir. The temperature simulations were sensitive to outlet elevation; thermal stratification was most pronounced for outlet elevation 7,440 ft. Thermal stratification was less developed in Wolford Mountain Reservoir during years when inflow discharge was unusually large (as simulated using the stream discharge from 1984), especially if the outlet was at 7,410 ft. Outflow temperature from Wolford Mountain Reservoir in normal runoff years that had normal reservoir operations could be expected to warm to about 9 to $10^{\circ} \mathrm{C}$ by early 0ctober with the outlet at 7,410 or $7,420 \mathrm{ft}$ and to about $12{ }^{\circ} \mathrm{C}$ by mid-September with the outlet at 7,440 $\mathrm{ft}$. Outflow temperature from Wolford Mountain Reservoir in less than normal runoff years may depend on reservoir storage and outflow discharge in late summer. Simulated outflow temperatures with the outlet at 7,410 or 7,420 ft were about $14{ }^{\circ} \mathrm{C}$ in late summer of 1977 , when simulated operations decreased reservoir storage to less than 40-percent capacity. If the reservoir was more full during the summer of a relatively dry year (simulation for 1987), thermal stratification was slightly more pronounced and persisted later into the season, and outflow temperature was colder than for the other years simulated. 
Specific conductance was modeled as a conservative constituent using a routine in the temperature model and an assumed specific-conductance profile at the start of the simulation periods. The simulation of specific conductance assessed only relative changes of specific conductance in the proposed reservoirs at different runoff conditions. Generally, specific conductance in the epilimnion in the reservoirs will be more diluted during greater than normal runoff years. The runoff in a drought year (simulations for 1977) had minimal effect on specific-conductance profiles. Specific-conductance profiles for Wolford Mountain Reservoir were dependent on reservoir outlet elevation, but specific conductance of the outflow was relatively unaffected by outlet level. The reservoirs would cause a reduction of variation in downstream specific conductance in Rock and Muddy Creeks.

The concentration profiles for dissolved solids and major inorganic constituents in the proposed reservoirs and concentrations in the outflows may qualitatively be similar to the specific-conductance simulations. There would be a dampening of dissolved-solids concentrations in Rock and Muddy Creeks by the reservoirs. Water in Rock Creek Reservoir would be composed primarily of calcium and bicarbonate ions. Water in Wolford Mountain Reservoir would be composed primarily of calcium, sulfate, and bicarbonate ions. Changes to concentrations of major inorganic constituents caused by ground-water inflow, evaporation, and leaching from the bottom of the reservoir at the Wolford Mountain are not discussed in this report.

Two models to predict total-phosphorus concentration were examined using data collected in 1986 and 1987. Measured total-phosphorus concentrations in Williams Fork and Green Mountain Reservoirs were within the 95-percent confidence intervals of the models. Total-phosphorus concentrations were simulated for the proposed reservoirs for water years 1985-87, which were the only years when concurrent water-quality and stream-discharge data were collected. Simulated total-phosphorus concentrations in Rock Creek Reservoir ranged from 0.007 to $0.019 \mathrm{mg} / \mathrm{L}$, and concentrations in Wolford Mountain Reservoir ranged from 0.049 to $0.11 \mathrm{mg} / \mathrm{L}$. The potential for eutrophication would be substantial at Wolford Mountain Reservoir based on estimated total-phosphorus concentrations. However, much of the total-phosphorus load in Muddy Creek may be attached to particulate matter, which may settle out of the water impounded in the reservoir. Other factors such as water temperature and hydraulic residence time could diminish the potential for eutrophication of Wolford Mountain Reservoir.

Models for estimating total-nitrogen concentration also were tested using data collected from the existing reservoirs. Measured total-nitrogen concentrations were within the 95-percent confidence intervals of three models. Simulated total-nitrogen concentrations (1985-87 water years) in Rock Creek Reservoir were 0.3 to $0.4 \mathrm{mg} / \mathrm{L}$ and in Wolford Mountain Reservoir were about 0.7 to $0.8 \mathrm{mg} / \mathrm{L}$.

Dissolved oxygen was evaluated only in terms of dissolved-oxygen data for reservoirs in the study area (Williams Fork and Green Mountain Reservoirs) and biochemical-oxygen demand (BOD) data collected for Rock and Muddy Creeks. On the basis of dissolved-oxygen profiles measured in 1986 and 1987, dissolvedoxygen concentrations were less than $5 \mathrm{mg} / \mathrm{L}$ in deep layers of thermally 
stratified reservoirs during late summer. The minimum concentrations measured were about $3 \mathrm{mg} / \mathrm{L}$. BOD concentrations (both 5- and 20-day values) were larger in samples collected from Muddy Creek than in the samples collected from Rock Creek.

Algal growth at the proposed reservoirs was assessed by modeling chlorophyll (as chlorophyl1-a) concentrations. Four models for estimating chlorophyl1 concentrations were examined using chlorophyl1 data collected in 1987 from Williams Fork and Green Mountain Reservoirs. Measured chlorophyll concentrations were within the 95-percent confidence intervals of all models; however, the confidence intervals are quite broad for these models. Simulated total-phosphorus and total-nitrogen concentrations for 1985-87 water years were used to simulate chlorophyll concentrations for the proposed reservoirs. The simulated chlorophyll concentrations in Rock Creek Reservoir ranged from 2.4 to $4.9 \mu \mathrm{g} / \mathrm{L}$. Those chlorophyll concentrations are similar to measured chlorophyll concentrations in Williams Fork and Green Mountain Reservoirs. The simulated chlorophyll concentrations for Wolford Mountain Reservoir, using chlorophyll models based only on total-phosphorus concentrations, were 21 to $51 \mu \mathrm{g} / \mathrm{L}$. Using a model that predicts chlorophyll concentration from totalphosphorus and total-nitrogen concentrations, simulated chlorophyll concentrations ranged from 14 to $21 \mu \mathrm{g} / \mathrm{L}$. A model that incorporates inorganic suspended-solids and total-phosphorus concentrations to predict chlorophyll concentration will predict decreasing chlorophyll as concentrations of inorganic suspended solids increase because of the decrease of light in the reservoir. Inorganic suspended solids may affect algal growth and consequently chlorophyll concentration at Wolford Mountain Reservoir because of large suspended-sediment discharge in Muddy Creek during spring runoff. The estimated chlorophyll concentrations were 9.4 to $29 \mu \mathrm{g} / \mathrm{L}$ with $25 \mathrm{mg} / \mathrm{L}$ of inorganic suspended solids in Wolford Mountain Reservoir. Simulated chlorophyll concentrations for Wolford Mountain Reservoir may be overestimated by the chlorophyll models. Algal growth, and subsequently chlorophyll concentration, may be substantially affected by other factors such as water temperature, hydraulic residence time, and zooplarkton grazing.

Algal growth at the proposed reservoir sites also was examined using algal-growth-potential (AGP) data collected from Rock and Muddy Creeks in April, July, and September during 1987. Algal growth in water from Rock Creek may be limited by availability of nitrogen, and increased phosphorus input to Rock Creek may not cause a large increase in algal growth in stream water. The AGP samples from Rock Creek had substantial increases in algal growth when nitrogen was added. Samples collected in April and July from Muddy Creek had additional algal growth when 0.03 dissolved phoshorus was added, which indicates that much of the total-phosphorus concentration in Muddy Creek was suspended phosphorus and was filtered out of the sample for AGP analysis. The samples collected in April and July from Muddy Creek had substantially more algal growth when nitrogen was added, indicating possible nitrogen limitation in water from Muddy Creek. The sample collected in September from Muddy Creek had less algal growth than the AGP samples collected in April and July. Possible causes for the decreased algal growth may be salinity interference, presence of a toxic element or compound that was not present in earlier samples, or depletion of an unknown nutrient. Those causes are applicable only to the test alga used in the AGP test. 
Previous studies have estimated the sediment discharge and reservoir sedimentation rates for Rock Creek Reservoir and for Wolford Mountain Reservoir. Those estimates were revised using additional sediment and streamdischarge data. The annual total-sediment discharge in Rock Creek was revised from 768 to 799 tons/yr (1953-80 water years). Rock Creek Reservoir would lose less than 1-percent storage capacity after 100 years at the revised sediment-discharge rate, which was the same conclusion reported in a previous study. The revised total-sediment discharge for Muddy Creek was 92,910 tons/yr for water years 1983-87. Results from a previous study were 83,000 tons/yr for water years 1983-85. Wolford Mountain Reservoir would lose about 11-percent storage capacity after 100 years using the revised annual totalsediment discharge. A 10-percent storage-capacity loss after 100 years was reported in a previous study.

The bed material downstream from the proposed.damsites on Rock and Muddy Creek was considered large enough to form armoring layers that eventually would inhibit channel degradation. A method based on formation of an armoring layer was used to estimate depth of degradation for short reaches downstream from the proposed damsites. The computed depth of degradation for a reach downstream from the Rock Creek damsite was $0.19 \mathrm{ft}$ and for a reach downstream from the Muddy Creek damsite was $0.38 \mathrm{ft}$. Those results are applicable only to a short reach downstream from each damsite; a more comprehensive assessment of channel morphology for Rock and Muddy Creeks is presented in a Supplemental Draft Environmental Impact Statement.

\section{SELECTED REFERENCES}

Adams, D.B., 1974, A predictive mathematical model for the behavior of thermal stratification and water quality of Flaming Gorge Reservoir, UtahWyoming: Cambridge, Mass., Massachusetts Institute of Technology, unpublished M.S. thesis, 213 p.

Bachmann, R.W., 1981, Prediction of total nitrogen in lakes and reservoirs, in Restoration of lakes and inland waters, International symposium on inland waters and lake restoration, 1981, Proceedings: U.S. Environmental Protection Agency Report 440/5-81-010, p. 320-324.

Brown, R.T., Hauser, G.E., McKinnon, M.K., and Shiao, M.C., 1985, Twodimensional modeling of Fort Loudon Reservoir water quality: Norris, Tenn., Tennessee Valley Authority, Water Systems Development Report WR28-1-10-100, $93 \mathrm{p}$.

Butler, D.L., 1987, Sediment discharge in Rock Creek and the effect of sedimentation rate on the proposed Rock Creek Reservoir, northwestern Colorado: U.S. Geological Survey Water-Resources Investigations Report 874026, $23 \mathrm{p}$.

Canfield, D.B., and Bachmann, R.W., 1981, Prediction of total phosphorus concentrations, chlorophyll a, and Secchi disk depths in natural and artificial lakes: Canadian Journal of Fisheries Aquatic Science, v. 38, no. 4, p. 414-423.

Carlson, R.E., 1977, A trophic state index for lakes: Limnology and Oceanography, v. 22 , no. 2, p. 361-369.

Chow, V.T., 1959, Open channel hydraulics: New York, McGraw-Hill, 680 p.

Colby, B.R., and Hembree, C.H., 1955, Computations of total sediment discharge, Niobrara River near Cody, Nebraska: U.S. Geological Survey Water-Supply Paper 1357, 187 p. 
Cornett, R.J., and Rigler, F.H., 1980, The areal hypolimnetic oxygen deficit: An empirical test of the model: Limnology and Oceanography, v. 25, no. 4, p. 672-679.

Dillon, P.J., and Rigler, F.H., 1974a, A test of a simple nutrient budget model predicting the phosphorus concentration in lake water: Journal of Fishery Resources Board of Canada, v. 31., no. 11, p. 1771-1778. 1974b, The phosphorus-chlorophyl1 relationship in lakes: Limnology and Oceanography, v. 19, no. 5, p. 767-773.

Eddy, R.M., and Fox, R.L., 1976, Green Mountain Reservoir-Lower Blue River study, Colorado: Denver, U.S. Environmental Protection Agency, Region 8, EPA-908/2-77-003, $100 \mathrm{p}$.

Emmett, W.W., 1980, A field calibration of the sediment-trapping characteristics of the Helley-Smith bedload sampler: U.S. Geological Survey Professional Paper 1139, $44 \mathrm{p}$.

Ferguson, R.I., 1986, River loads underestimated by rating curves: WaterResources Research, v. 22, no. 1, p. 74-76.

Hirsch, R.M., 1982, A comparison of 4 streamflow record extension techniques: Water Resources Research, v. 18, no. 4, p. 1081-1088.

Hoyer, M.V., and Jones, J.R., 1983, Factors affecting the relation between phosphorus and chlorophyll a in Midwestern reservoirs: Canadian Journal of Fisheries Aquatic Science, v. 40, no. 2, p. 192-199.

Huber, W.C., and Harleman, D.R.F., 1968, Laboratory and analytical studies of the thermal stratification of reservoirs: Cambridge, Mass., Massachusetts Institute of Technology, Hydrodynamics Laboratory Report no. $112,277 \mathrm{p}$.

Hutchinson, G.E., 1957, A treatise on limnology, volume 1: New York, John Wiley, $1015 \mathrm{p}$.

Jarrett, R.D., 1985, Determination of roughness coefficients for streams in Colorado: U.S. Geological Survey Water-Resources Investigations Report $85-4004,54 \mathrm{p}$.

Koberg, G.E., 1964, Methods to compute long-wave radiation from the atmosphere and reflected solar radiation from a water surface: U.S. Geological Survey Professional Paper 272-F, p. 107-136.

LaBaugh, J.W., 1985, Uncertainty in phosphorus retention, Williams Fork Reservoir, Colorado: Water-Resources Research, v. 21, no. 11, p. 1684-1692.

LaBaugh, J.W., and Winter, T.C., 1984, The impact of uncertainties in hydrologic measurement on phosphorus budgets and empirical models for two Colorado reservoirs: Limnology and Oceanography, v. 29, no. 2, p. 322-339.

Lewis, W.M., Jr., Saunders, J.F., Crumpacker, D.W., Sr., and Brendecke, C.M., 1984, Eutrophication and land use, Lake Dillon, Colorado: New York, Springer-Verlag, $202 \mathrm{p}$.

Markofsky, Mark, and Harleman, D.R.F., 1971, A predictive model for thermal stratification and water quality in reservoirs: Cambridge, Mass., Ralph M. Parsons Laboratory for Water Resources and Hydrodynamics, Report 134, 283 p.

Mueller, D.K., 1982, Mass balance model estimation of phosphorus concentrations in reservoirs: Water Resources Bulletin, v. 18, no. 3, p. 377-382.

National Oceanic and Atmospheric Administration, 1957, Climatological data, Colorado, May through October, 1957: Asheville, N.C., National Climatic Center, v. 62, no. 5-10. 1962, Climatological data, Colorado, May through October, 1962: Asheville, N.C., National Climatic Center, v. 67, no. 5-10. 
National Oceanic and Atmospheric Administration, 1972, Climatological data, Colorado, May through October, 1972: Asheville, N.C., National Climatic Center, v. 77, no. 5-10.

1976, Climatological data, Colorado, May through October, 1976:

Asheville, N.C., National Climatic Center, v. 81, no. 5-10.

1977, Climatological data, Colorado, May through October, 1977:

Asheville, N.C., National Climatic Center, v. 82, no. 5-10.

1984, Climatological data, Colorado, May through October, 1984:

Asheville, N.C., National Climatic Center, v. 89, no. 5-10.

1986, Climatological data, Colorado, May through October, 1986:

Asheville, N.C., National Climatic Center, v. 91, no. 5-10.

1987, Climatological data, Colorado, May through October, 1987:

Asheville, N.C., National Climatic Center, v. 92, no. 5-10.

Reckhow, K.H., 1979, Uncertainty analysis applied to Vollenweider's

phosphorus loading criterion: Journal of Water Pollution Control

Federation, v. 50, no. 8, p. 2123-2128.

Reckhow, K.H., and Simpson, J.T., 1980, An empirical study of factors affecting blue-green versus nonblue-green algal dominance in lakes: East Lansing, Mich., Michigan State University, Institute of Water Research, $99 \mathrm{p}$.

Ruddy, B.C., 1987, Sediment discharge in Muddy Creek and the effect of sedimentation rate on the proposed Wolford Mountain Reservoir near

Kremmling, Colorado: U.S. Geological Survey Water-Resources Investigations Report 87-4011, $22 \mathrm{p}$.

Shapiro, Joseph, 1978, The need for more biology in lake restoration: U.S. Environmental Protection Agency, EPA 440/5-79-001, 17 p.

Simons, D.B., and Senturk, Fuat, 1977, Sediment transport technology: Fort Collins, Colo., Water-Resources Publications, 807 p.

Smith, V.H., 1982, The nitrogen and phosphorus dependence of algal biomass in lakes--An empirical and theoretical analysis: Limnology and Oceanography, v. 27, no. 6, p. 1101-1112.

1985, Predictive models for the biomass of blue-green algae in lakes: American Water Resources Association, Water Resources Bulletin, v. 21, no. 3, p. 433-439.

Spahr, N.E., and Ruddy, B.C., 1983, Reservoir evaporation in central Colorado: U.S. Geological Survey Water-Resources Investigations Report 83-4103, $232 \mathrm{p}$.

Strand, R.I., and Pemberton, E.L., 1982, Reservoir sedimentation: Denver, Colo., U.S. Bureau of Reclamation, $48 \mathrm{p}$.

Tweto, Ogden, 1981, Geologic map of the Craig 1x2 quadrangle, northwestern Colorado: U.S. Geological Survey Miscellaneous Investigations Series Map I-972, scale $1: 250,000$.

U.S. Forest Service, 1988, Supplemental Draft Environmental Impact Statement for the Rock Creek/Muddy Creek Reservoir, Routt and Grand Counties, Colorado: Lakewood, Colo., U.S. Forest Service, Rocky Mountain Region, $440 \mathrm{p}$.

Vanoni, V.A., ed., 1975, Sedimentation engineering: New York, American Society of Civil Engineers, Manuals and Reports on Engineering Practices no. 54, $745 \mathrm{p}$.

Vollenweider, R.A., 1976, Advances in defining critical loading levels for phosphorus in lake eutrophication: Memorie dell' Istituto Italino di Idrobiologia, v. 33, p. 53-83. 
Walker, W.W., 1979, Use of hypolimnetic oxygen deficit rate as a trophic state index for lakes: Water Resources Research, v. 15, no. 6, p. 1463-1470.

Western Engineers, Inc., 1983, Wolford Mountain Reservoir project feasibility study: Grand Junction, Colo., 132 p.

1984, Rock Creek water supply study: Grand Junction, Colo., 17 p.

Williams, G.P., and Wolman, M.G, 1984, Downstream effects of dams on alluvial rivers: U.S. Geological Survey Professional Paper 1286, 83 p. 1986, Changes in rivers downstream from dams, in National Water Summary 1985--Hydrologic events and surface-water resources: U.S. Geological Survey Water-Supply Papér 2300, p. 83-88.

Yahnke, J.W., 1981, Water quality of the proposed Norden Reservoir, Nebraska, and its implications for fishery management: Denver, Colo., U.S. Bureau of Reclamation Report REC-ERC-81-8, $50 \mathrm{p}$. 